Міністерство освіти і науки України

Національний університет «Острозька академія»

Варшавський університет

Брестський державний університет імені Олександра Пушкіна Гомельський державний університет імені Франциска Скорини Херсонський державний університет

\title{
ЛЕКСИКО-ГРАМАТИЧНА СИСТЕМА УКРАЇНСЬКОЇ МОВИ В КОМУНІКАТИВНОМУ ВИМІРІ
}

\author{
МАТЕРІАЛИ \\ Міжнародної наукової інтернет-конференції
}

12-13 березня 2020 року

м. Острог

Острог

Видавництво Національного університету «Острозька академія» 2020 


\author{
Рекомендовано до друку на засіданні кафедри \\ української мови і літератури \\ Національного університету «Острозька академія» \\ (протокол № 9 від 7 березня 2020 року)
}

\title{
Редакційна колегія:
}

Хом'як I. М., доктор педагогічних наук, професор, академік АН ВШ України, завідувач кафедри української мови і літератури Національного університету «Острозька академія» (відповідальний редактор);

Омельчук С. А., доктор педагогічних наук, доцент, професор кафедри слов'янської філології, перший проректор Херсонського державного університету;

Кочерга С. О., доктор філологічних наук, професор кафедри української мови і літератури Національного університету «Острозька академія».

Лексико-граматична система української мови в комунікативному вимірі: збірник матеріалів Міжнародної наукової інтернет-конференції, м. Острог, 12-13 березня 2020 року / редкол. І. М. Хом'як (відп. ред.) та ін. Острог: Видавництво Національного університету «Острозька академія», 2020. 76 с.

\section{DOI $10.25264 / 7.03 .20230$}

У збірнику матеріалів Міжнародної наукової інтернет-конференції «Лексико-граматична система української мови в комунікативному вимірі», яка відбулася 12-13 березня 2020 року на базі Національного університету «Острозька академія», представлено тези доповідей учасників, у яких відображено різноаспектні дослідження актуальних проблем сучасної української філології й лінгводидактики.

УДК 81 (082)

ББК 81я431

Матеріали опубліковано в авторській редакиії.

За зміст тез доповідей, допущені помилки і неточності відповідають автори публікацій. 


\section{MICT}

\section{ЛЕКСИКО-СЕМАНТИЧНІ ОСОБЛИВОСТІ УКРАЇНСЬКОЇ МОВИ В СУЧАСНОМУ ДИСКУРСІ}

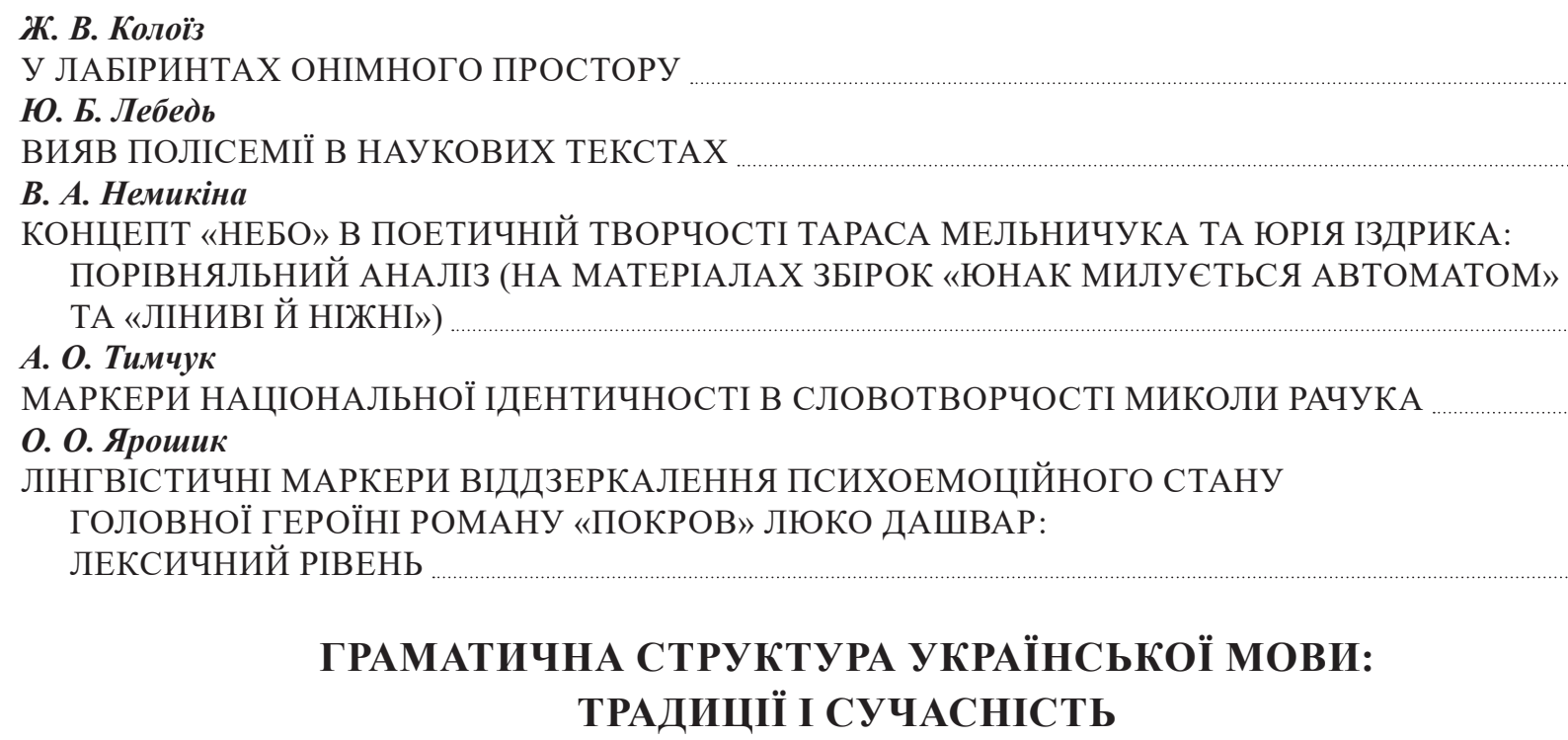

ГРАМАТИЧНА СТРУКТУРА УКРАЇНСЬКОЇ МОВИ: ТРАДИЦІЇ І СУЧАСНІСТЬ

Н. М. Мединська

ФУНКЦІЙНА НЕОДНОРІДНІСТЬ ДІЄПРИКМЕТНИКІВ

І. Д. Шмілик

ВАРІАНТНІ ФОРМИ ДАВАЛЬНОГО ВІДМІНКА ІМЕННИКІВ У ПОЕЗІЇ КАМЕНЯРА

I. Ю. Рабчук

ЛЕКСИЧНЕ НАПОВНЕННЯ АПОЗИТИВНИХ СИНТАКСЕМ

ТЕМАТИЧНОГО ДІАПАЗОНУ «НАВКОЛИШНІЙ СВІТ ЛЮДИНИ»

В. М. Кухарська

ДО ПРОБЛЕМИ ПРИЙОМІВ ПЕРЕКЛАДУ НЕОЛОГІЗМІВ

\section{КОМУНІКАТИВНИЙ ВИМІР ФУНКЦЮЮВАННЯ УКРАЇНСЬКОЇ МОВИ}

\footnotetext{
о. Д. Кулик

РОЛЬ ЧАСТКОВОГО СЛОВОТВІРНОГО АНАЛІЗУ ТЕКСТУ

В СТИМУЛЮВАННІ МОВЛЕННЄВОЇ РЕФЛЕКСІЇ УЧНІВ

Л. М. Овсієнко

ТЕКСТ У КОМУНІКАТИВНОМУ ВИМІРІ

С. Романюк, К. Якубовська-Кравчик, М. Замбжицька

МОВА І КУЛЬТУРА ЯК НЕВІД'ЄМНІ АТРИБУТИ УКРАЇНСЬКОЇ ТОЖСАМОСТІ.

УРАХУВАННЯ КУЛЬТУРОЗНАВЧОГО НАПРЯМУ ПРИ УКЛАДЕННІ ПІДРУЧНИКІВ

ІЗ УКРАЇНСЬКОЇ ЯК ІНОЗЕМНОЇ ДЛЯ СТУДЕНТІВ ВНЗ ПОЛЬЩ

T. Ф. Семаико

ЩОДО РОЗМЕЖУВАННЯ ПОНЯТЬ «НАЦІОНАЛЬНИЙ СТЕРЕОТИП»-

«ЕТНІЧНИЙ СТЕРЕОТИП»

I. М. Хом'як

УКРАЇНСЬКА МОВА - ГАРАНТІЯ ЗБЕРЕЖЕННЯ НАЦІОНАЛЬНОЇ ІДЕНТИЧНОСТИ

О. М. Антончук

ФОРМИ ДІЛОВОЇ КОМУНІКАЦІЇ У ПРОЦЕСІ ВИВЧЕННЯ КУРСУ «УКРАЇНСЬКА МОВА ЗА ПРОФЕСІЙНИМ СПРЯМУВАННЯМ»
} 


\section{Г. В. Гайович}

КОМУНІКАТИВНІ НАВИЧКИ ТА УСПІШНА КАР'СРА ДЕРЖСЛУЖБОВЦЯ.

ЯК ЦЕ ПОСДНУЄТЬСЯ?

Т. В. Костолович

СУЧАСНІ ФОРМИ ОРГАНІЗАЦІЇ НАВЧАННЯ У ЗАКЛАДАХ ВИЩОЇ ОСВІТИ

У ПРОЦЕСІ ВИВЧЕННЯ ЛІНГВІСТИЧНИХ ДИСЦИПЛІН

Н. I. Скрипник

ДИСКУРС ЯК КЛЮЧОВА ОДИНИЦЯ МОВЛЕННСВОЇ ДІЯЛЬНОСТІ

3. В. Столяр

ПСИХОЛОГО-ПЕДАГОГІЧНІ ЗАСАДИ ПОЧАТКОВОГО НАВЧАННЯ УКРАЇНСЬКОЇ МОВИ

В УМОВАХ НУШ

Н. В. Шульжук

МОВЧАННЯ ЯК НУЛЬОВИЙ МОВЛЕННСВИЙ АКТ У СТРУКТУРІ ДІАЛОГІЧНОГО ДИСКУРСУ

Х. М. Карповець

СУЧАСНІ ПІДХОДИ ДО ФОРМУВАННЯ ПРАВОПИСНОЇ КОМПЕТЕНТНОСТІ

МАЙБУТНІХ ФІЛОЛОГІВ

М. Саневська

СУЧАСНА ЛЕКСИКА ПОВСЯКДЕННОГО ЖИТТЯ У НАВЧАННІ УКРАЇНСЬКОЇ МОВИ ЯК IHOЗЕМНӦ̈

М. А. Матевоцук

МЕТОДИЧНІ АСПЕКТИ ВИКОРИСТАННЯ ТЕХНОЛОГІЇ «ЩОДЕННІ 5» У ПРОЦЕСІ ФОРМУВАННЯ КОМУНІКАТИВНОЇ КОМПЕТЕНТНОСТІ УЧНІВ ПОЧАТКОВОЇ ШКОЛИ

\section{МОДЕЛІ ЛІТЕРАТУРНОЇ КОМУНІКАЦЇ̈ В ХУДОЖНЬОМУ ТЕКСТІ}

\section{O. A. Bicuч}

МЕТАДРАМАТИЧНІ СТУДІЇ У СВІТЛІ ШЕКСПІРОЗНАВСТА

C. О. Кочерга

ІМЕННИЙ КОД ПРОСТОРУ В ПОЕТИЧНОМУ ТЕКСТІ

Марія Моклиця

СИМВОЛІЧНЕ МОВЛЕННЯ ТА ІНТЕРПРЕТАЦІЯ ТЕКСТУ (ДРАМАТУРГІЯ ЛЕСІ УКРАЇНКИ)

Д. Ю. Боклах

ГОМОДІЄГЕТИЧНИЙ НАРАТИВ У ТВОРЕННІ ТОПОСУ КИЄВА ПОВІСТІ «БЛИЗНЕЦЫ»

Т. ШЕВЧЕНКА

о. А. Демчук

ІМАГОЛОГІЧНЕ ПРОТИСТАВЛЕННЯ ЕТНОТИПІВ У ПОЕЗІЯХ ВАСИЛЯ МАХНА

С. М. Марчук

ЕКЗОТИЧНІ МОТИВИ В СУЧАСНОМУ ПОЕТИЧНОМУ ТРАВЕЛОЗІ

О. А. Подвишенний

ІМАГОЛОГІЧНЕ УЯВЛЕННЯ ПРО ЄВРОПУ НА ШПАЛЬТАХ ЧАСОПИСУ «ВОЛИНЬ» ПІД ПРОВОДОМ УЛАСА САМЧУКА

I. Ю. Давидюк

РОСЛИННІ ОБРАЗИ В ХУДОЖНЬОМУ СВІТІ ОКСАНИ ЛЯТУРИНСЬКОЇ-ПОЕТЕСИ:

ЕСТЕТИКА І СЕМАНТИКА

T. В. Марценюк

ОБРАЗ ІНШОГО В ПОВІСТІ НАТАЛІ ЯСІНОВСЬКОЇ «УКРАЇНКА ПО-АМЕРИКАНСЬКИ»

С. О. Омелянчук

(НЕ)ВІЛЬНИЙ ШЛЮБ ТА ІНШІ ГЕНДЕРНІ ПРОБЛЕМИ ДРАМИ

ВОЛОДИМИРА ВИННИЧЕНКА «ПРИГВОЖДЕНІ»

Н. В. Савчук

«ПОЛЬОВІ ДОСЛІДЖЕННЯ З УКРАЇНСЬКОГО СЕКСУ» ОКСАНИ ЗАБУЖКО

У ПОСТРАДЯНСЬКІЙ КУЛЬТУРНІЙ РЕЦЕПЦІЇ 


\title{
ЛЕКСИКО-СЕМАНТИЧНІ ОСОБЛИВОСТІ УКРАЇНСЬКОЇ МОВИ В СУЧАСНОМУ ДИСКУРСІ
}

УДК 811.161.1'373. 2'23

\author{
Ж. В. Колоӥз, \\ доктор філологічних наук, професор, \\ завідувач кафедри української мови \\ Криворізького державного педагогічного університету, \\ м. Кривий Piг \\ koloiz.zv@gmail.com
}

\section{У ЛАБІРИНТАХ ОНІМНОГО ПРОСТОРУ}

Нині немає жодних підстав сумніватися в тому, що ономастика відбулася як наука, яка систематизує знання про наявні реалії довколишнього світу. Ї̈̈ формування супроводжувалося відбором наукових фактів, перевіркою різних гіпотез, формулюванням певних законів, побудовою і розбудовою теорій, появою й модифікацією відповідної терміносистеми.

Українська ономастика, як і ономастика загалом, попри вагомі здобутки (А. Зубко) має беззаперечні перспективи розвитку, що переконливо засвідчують результати наукових пошуків (М. Торчинський), має й певні проблеми (О. Карпенко), які стосуються передовсім гармонізації термінології (І. Казимирова), їі уніфікації, стандартизації і т. ін.

Дослідження власних найменувань тих чи тих об'єктів відбувалося не лише швидкими темпами, але й упродовж останніх десятиліть значно актуалізувалося, що, власне, і спричинило так званий «ономастичний термінологічний вибух» (іншими словами, «неологічний бум»), оновило традиційну терміносистему за рахунок інновацій різного «гатунку», частина 3 яких отримала кодифікацію [1], а інша - функціонує в науковому обігові зазвичай в індивідуально-авторському оформленні й потрактуванні. У лабіринтах онімного простору іноді досить важко зорієнтуватися й знайти вихід. А відтак - питання про осмислення традиційних ономастичних термінів, їх переосмислення, удосконалення і т. ін. залишається актуальним.

Не викликає принципових заперечень твердження деяких мовознавців (О. Матвєєв, В. Супрун) про те, що критичну оцінку необхідно дати й тим термінам, які давно стабілізувалися в системі. Ідеться насамперед про найменування самої наукової царини і низки ключових понять: вочевидь, слово ономастика варто було б використовувати для позначення «сукупності власних імен», а для номінації мовознавчої царини більш придатним, на думку науковців, $є$ термін ономатологія; того, хто займається ономатологічними дослідженнями, слід іменувати ономатологом; того, хто працює над створенням спеціальних словників, - ономатографом. Відповідні терміни (ономатологія - ономастика - ономастикон - ономатографія - ономатолог - ономатограф) хоч і порушують усталені лінгвістичні традиції, однак засвідчують звичні словотвірні механізми й корелюють із термінолексемами на зразок лексикологія - лексика - лексикон - лексикографія - лексиколог - лексикограф [3, с. 7-9]. Зауважимо: термін ономатологія, кодифікований ще в 70-х роках XX ст. [4], має і рідномовний відповідник назвознавство (І. Герус-Тернавецька).

Не викликає спростувань і те, що традиційне ономастика походить від давньогрецького $\delta v o \mu \alpha \sigma \tau \imath к \dot{~}$ - «мистецтво давати імена», утвореного від о́vo $\mu \alpha$ - «ім'я», «назва», і це «мистецтво давати імена», вочевидь, стосується як індивідуальних найменувань окремих об'єктів (пор.: ономастиком у давній Греції називали офіційний професіонал, вишколений у сфері надавання імені дитині, який завершував відповідну релігійно-обрядову урочистість, іменовану як ономастерія), так і узагальнених назв однотипних предметів, адже в широкому потрактуванні $і м$ 'я - «те саме, що й найменування» (пор.: називати речі своїми іменами). Така контамінація простежується й певних наукових доробках, у яких для позначення і власних, і загальних назв використовують терміни зоонім, орнітонім, фітонім, глютонім (наприклад, фразеологічні одиниці з компонентом-фітонімом, компонентом-орнітонімом і т. ін.).

(С) Ж. В. Колоїз, 2020 
Окрім того, давньогрецьку літеру $\boldsymbol{v}$, яку називають $\boldsymbol{\mu i}$, вимовляють, як звук о короткий [2, с. 14], тобто давньогрецьке óvo $\alpha \alpha$ звучить як [онома]. Відповідно до цього і згідно з чинними законами словотворення на позначення аналізованої мовознавчої царини, мабуть, доречніше було б використовувати термін ономологія < онома + логія (пор.: ономолог, ономографія, ономограф). У такому разі очевидними є суперечності й щодо найменування одиниці дослідження, оскільки традиційне онім з'явилося нетрадиційним шляхом. Беручи до уваги продукування інших так званих емічних лінгвістичних одиниць на зразок лексема, семема, фонема, дериватема і т. ін., закономірним могло б бути й продукування термінологічної одиниці на зразок ономема.

Викликає занепокоєння й те, що доволі складно знайти вихід із класифікаційних лабіринтів онімного простору, поділеного на поля / підполя, сектори / підсектори, сегменти / підсегменти, елементи / піделементи тощо [5]. Їх кількість, іноді заплутане розташування, поєднання, переплетення, переходи i т. ін. не сприяють адекватному сприйняттю, розумінню, потрактуванню. Наприклад, з-поміж зоонімів виокремлюють: 1) пеконіми (гіппоніми, кіноніми, анасоніми, ансероніми, асіноніми, бовісоніми, галліноніми, індиконіми, камелоніми, капоніми, кунікулоніми, овісоніми, порконіми, тауроніми, фелоніми); 2) фероніми (бізононіми, вульпоніми, леоніми, лупусоніми, урсоніми, пардусоніми, мусоніми, драконіми, серпеноніми, буфоніми, гестудоніми, дельфіноніми, іхтіоними і т. ін.). Осягнення структури $\mathrm{i}$ змісту відповідних термінів, їх декодування неможливе без спеціальних фонових знань, лінгвістичної вправності, мовного чуття тощо. Десь-не-десь спрацьовує так звана народна етимологія (кіноніми «найменування фільмів», а насправді «найменування собак»). Як відомо, собаки (і не тільки!) бувають не лише домашніми (лат. pecus - «домашні тварини»), а й дикими (лат. ferus - «дикий звір»). Упадає в око занадто деталізоване (а подекуди й невиправдане) структурування. Так, з одного боку, драконіми (ящірки), серпеноніми (зміі), буфоніми (жаби), тестудоніми (черепахи) індивідуалізують плазунів, які потрапили в «домашні» умови або стали витвором творчої уяви митця (черепаха Tортила); 3 іншого, - за такого підходу поза увагою залишаються найменування уналежнених до тваринного світу павукоподібних, молюсків, морських зірок, черв’яків тощо. Кожне з полів є відкритим, у будь-який момент може модифікуватися унаслідок виокремлення нових елементів (скажімо, можна легко модифікувати парфумоніми за рахунок того, що вони об’ єднують найменування з інтегральними й диференційними семами - духів, одеколонів, лосьйонів, гелів, мила і т. ін., мають різне призначення тощо).

Ще одна проблема, яка спонукає до плідних наукових дискусій, термінологічний різнобій - використання різних термінів для означення одного й того ж поняття. Нещодавно онімний простір поповнився елементом на зразок ароматоніми (Є. Біла), уживаний у тому ж значенні, що й парфумоніми.

Суперечливим є визначення місця тих чи тих елементів у структурі відповідного простору. Наприклад, геортоніми подекуди уналежнюють до періодонімів, що їх кваліфікують як один із різновидів хрононімів [5, с. 551], або вважають чи то різновидом ідеонімів (І. Бочарова), чи то агіонімів / гагіонімів (І. Бочарова, Г. Тимошик) і т. ін. Немає одностайності й щодо використання деяких терміносполучень: термін культові геортоніми функціонує паралельно з термінами конфесійні (Ю. Браїлко), православні геортоніми (О. Андрєєва) чи то просто сакроніми (О. Белей) або релігіоніми (Ю. Михайлов). I таких моментів чимало. Вони спонукають до плідних наукових дискусій.

Узагальнюючи, зауважимо: так звана ономатологічна терміносистема, яка є результатом творчих наукових пошуків, лише певною мірою грунтована на традиції. Сучасне термінологічне розмаїття онімного простору потребує більш глибокого осмислення (переосмислення!) і більш виважених обгрунтувань, що сприятиме доступності, зрозумілості, точності, ясності, а відтак і науковості.

\section{Література:}

1. Бучко Д. Г., Ткачова Н. В. Словник української ономастичної термінології. Харків : Ранок-НТ, 2012.256 с.

2. Звонська-Денисюк Л. Л. Давньогрецька мова : підручник. Київ : Томіріс, 1997. 581 с.

3. Матвеев А. К. Ономастика и ономатология. Вопросы ономастики. 2005. № 2. С. 5-10.

4. Словник іншомовних слів / за ред. О. С. Мельничука. Київ : УРE, 1974. 776 с. URL : http://ukrajintsine.narod. ru/slovnyk_meln/index.html

5. Торчинський М. М. Структура онімного простору української мови : монографія. Хмельницький : Авіст, 2008. $550 \mathrm{c}$. 
УДК 161.2.81'23

\section{Ю. Б. Лебедь,}

кандидат філологічних наук, викладач,

Комунальний заклад вищої освіти

«Вінницький гуманітарно-педагогічний коледж», м. Вінниия,

iulialebed7@gmail.com

\section{ВИЯВ ПОЛІСЕМІЇ В НАУКОВИХ ТЕКСТАХ}

Семантика лексичних одиниць $є$ предметом досліджень багатьох лінгвістичних шкіл і напрямків, вивчається як явище системи мови з урахуванням усього набору значень і їх можливої реалізації в текстах, в основному художніх і публіцистичних.

Функціональний же аспект дослідження семантики, особливо в реальних текстах науки і техніки, залишається маловивченим. Це і зумовило актуальність дослідження.

У лексикографії для визначення межі багатозначного слова велике значення має визначення його основного, головного або центрального значення, тому в словникових статтях перше значення слова завжди $є$ головним, основним. Основне значення, навколо якого групуються інші часткові значення, розкриває семантичний потенціал багатозначного слова і визначає межі його семантичної структури. Часткові значення слова постійно змінюються в процесі мовної практики людини, при цьому воно набуває нових значень або варіанти значень, які, однак, не виходять за рамки його семантичного потенціалу.

Вважається, що науковий стиль характеризується відсутністю або крайньої обмеженістю багатозначності. Науковці по-різному трактують прояви полісемії в науковому стилі. Особливо вони наголошують на однозначності термінів. Полісемія термінів послаблює його функціональну позицію - визначення та однозначність зафіксованого в ньому поняття [2, с. 111].

Попри те що основною вимогою до термінологічної лексеми є однозначність, полісемія в терміносистемах - неминуче явище: терміни виникають постійно, їм притаманні ознаки природних лексичних одиниць, а отже й багатозначність [3, с. 176].

Яскравим прикладом $є$ тризначний термін термінологія, дефініції якого такі: 1) сукупність термінів певної мови (українська термінологія); 2) сукупність термінів певної галузі (лінгвістична термінологія); 3) наука про терміни. Багатозначність термінів науковці пояснюють тим, що з когнітивної точки зору, термін - мовний знак, семантика якого відображає певні етапи його пізнання $[4$, с. 139]: поряд із терміном словосполучення зустрічаємо мета мовленнєві вирази лексико-фразеологічні властивості словосполучення, соціолінгвістична обумовленість словосполучення, концептуальна повноцінність словосполучення, які є вказівкою на те, що словосполучення варто вивчати як складне явище, у якому взаємодіють лінгвістичні й екстралінгвістичні фактори.

У сфері термінології представлена також багатозначність, викликана різними поглядами вчених на те, який денотат і яке поняття варто позначати тим чи тим терміном. Таку полісемію вчені називають авторською багатозначністю [1, с. 51].

Отже, полісемія - регулярне явище у сфері функціонування термінів. Багатозначні терміни характеризуються полісемією двох типів: власною й авторською.

\section{Література:}

1. Борковский В. И., Кузнецов П. С. Историческая грамматика русского язика. Москва : Наука, 1965. 555 с.

2. Вереш М., Синьо В. Полісемія у німецькій християнсько-болгословській терміносистемі. Актуальні питання гуманітарних наук. Вип. 11. 2015. С. 110-114.

3. Закреницька Л. А. Англійська християнсько-богословська терміносистема: генезис, структура, семантика: дис. ... канд. філол. наук : 10.02.04. Хмельницький, 2011. 243 с.

4. Ляшук Н. Явище концептуальної багатозначності в українській термінологічній термінології (фрагмент аналізу). Лексикографічний бюлетень. 2010. №19. С. 137-145.

(ㄱ) Ю. Б. Лебедь, 2020 


\section{В. А. Немикіна,}

магістрантка Національного університету «Острозька академія»,

м. Oстрог

violeta.nemykina@oa.edu.ua

\section{КОНЦЕПТ «НЕБО» В ПОЕТИЧНІЙ ТВОРЧОСТІ ТАРАСА МЕЛЬНИЧУКА ТА ЮРІЯ ІЗДРИКА: ПОРІВНЯЛЬНИЙ АНАЛІЗ (НА МАТЕРІАЛАХ ЗБІРОК «ЮНАК МИЛУСТЬСЯ АВТОМАТОМ» ТА «ЛІНИВІ Й НІЖНІ»)}

Одним із ключових завдань сучасного мовознавства є вивчення когнітивної діяльності людини. Когнітивною діяльністю називають таку діяльність людини, яка пов'язана з необхідністю ідентифікувати та розрізняти об'єкти. У такому випадку мова є засобом вербалізації та концептуалізації навколишньої дійсності, а «концепт тісно пов'язаний з асоціативним простором лексеми і в ньому проявляється» [6, c. 101].

Процеси сприйняття людиною цієї дійсності реалізують у концептах. Термін «концепт» $є$ доволі розповсюдженим й актуальним у сучасних дослідженнях таких галузей, як когнітивна лінгвістика, когнітивна лінгвопоетика, лінгвокультурологія тощо. Також цим терміном послуговуються у таких науках, як філософія, культурологія, психологія. Проте робота над його розробкою й формуванням триває й досі. Окрім того, це поняття належить до числа нечітко визначених лінгвістичних категорій, оскільки сам термін «концепт» $€$ порівняно новим і не має однозначного вираження. Саме тому визначень поняття «концепт» $є$ велика кількість.

Поняття концепту досліджували Н. Арутюнова, М. Бахтін, В. Воробйов, Л. Ковбасюк, О. Кубрякова, В. Карасік, В. Красних, М. Лаюк, Д. Лихачов, Л. Мініч, 3. Попова, О. Селіванова, Г. Слишкін, Н. Совтис, І. Стернін, Е. Розвод, Н. Швець та ін.

Концепт - одиниця концептосфери, тобто впорядкованої сукупності одиниць мислення народу. Концепт містить в собі всі ментальні ознаки того чи того явища, які відображені свідомістю народу на певному етапі його розвитку. Таким чином, концепт у художньому творі - основне поняття, головна ідея та значення, відображені в тексті, культурно важливі для певного народу [7, с. 202].

У процесі пізнання світу в кожної людини формується логічно пов'язана між собою система концептів. Концепт як ментальне утворення у свідомості індивіда $є$ виходом у концептосферу соціуму, тобто культуру. Як зазначив М. Лаюк, «перехід концепту з авторської концептосфери до концептосфери мови збагачує і розширює національну концептосферу» [4, с. 221]. А концепт як одиниця культури - це фіксація колективного досвіду, який стає надбанням індивіда.

Поетичний концепт як одиниця ідіостилю поета посідає чільне місце у формуванні мовної особистості та мовної картини світу автора. Особливо цікавим є порівняння наявності та вербалізації концептів у творчості різних письменників, представників одного або різних поколінь.

Відтак порівняння поетичної творчості Тараса Мельничука, українського поета-дисидента, в'язня радянських таборів та жертви репресивної психіатрії, представника інтуїтивізму, із поетичною творчістю Юрія Іздрика, одного із найвизначніших українських митців постмодернізму та сучасності та творців станіславського феномену, викликає особливий науковий інтерес, особливо зважаючи на той факт, що обидва вони вихідці із Станіслава (сучасний Івано-Франківськ).

Для аналізу був вибраний концепт «небо». Великий тлумачний словник сучасної української мови подає такі визначення цього поняття: 1) видимий над поверхнею землі повітряний простір у формі купола; 2) за релігійними уявленнями - місце перебування богів, ангелів, святих; потойбічний світ, рай [1]. Можемо припустити, що в поетичних творах концепт «небо» підтверджує семантичне значення цієї лексеми. 
Оскільки 3. Попова та І. Стернін визначили сукупність всіх мовних засобів об'єктивації концепту як номінативне поле концепту і вважають мовними засобами об'єктивації концепту, які входять до номінативного поля концепту, прямі й похідні номінації концепту, однокореневі слова, контекстуальні синоніми й авторські номінації, стійкі словосполучення, словарні статті і цілі тематичні тексти, також фразеологічні одиниці і паремії [3, с. 48-49], то в збірках звернено увагу на лексему «небо», а також іiі однокореневі слова.

У збірці «Юнак милується автоматом» натрапляємо на концепт «небо» 15 разів. Здебільшого Тарас Мельничук вживає його в контексті повітряного простору, «верху». Наприклад, «і до неба полізуть бо ж вік космонавтики» [5, с. 33], «димарі закинули ноги / у небеса: / краса/ синій млин неба / зробити чорним треба» [5, с. 60], «пливе по небі / біла хмаринка» [5, с. 41] «дивлюсь на камені / на небо / на ліс / на сонце» [5, с. 116].

Проте в деяких випадках семантика «неба» ніби межує між фізичним та духовним виміром. Це наштовхує на думку, що на філософському рівні небо пов'язане із чимось вищим, світлим, нетутешнім. Наприклад, «неба не було / негаразд без неба / аж дощ болить» [5, с. 31], «я їм готов і серия вділити / і неба прихилити» [5, с. 77].

Автор використовує такі епітети на позначення неба: синс: «Під небом вечірнім / під небом синім / де крутяться зір коліщатка» [5, с. 113], «Було їй досить і синього неба / $і$ поля / і росяних снів» [5, с. 131]; вечірнс: «Під небом вечірнім / під небом синім / де крутяться зір коліщатка» [5, с. 113]; залантуховане: «що я в залантухованому небі крижнем впав» [5, с. 148].

У збірці «Ліниві й ніжні» натрапляємо на концепт «небо» 66 разів. Тут так само часто автор вживає цей концепт на позначення суто фізичного простору, а також на позначення фізичного й духовного простору водночас. Проте на відміну від Тараса Мельничука, Юрій Іздрик більше метафоризує концепт «небо», майже у всіх випадках вживання цієї лексеми відбувається у синтаксично залежних конструкціях, що надає цьому концепту більшу гаму відтінків і мінімальних сенсів. Також Юрій Іздрик частіше звертається до неба, маючи на увазі Бога, та вкладаючи релігійні сенси.

У збірці бачимо концепт «небо» в поєднанні з такими образами: «замість неба - старий парамутний шовк» [2, с. 27], «хоч на небі так самоумовність безмовність і пустка» [2, с. 38], «усе буде добре під небом померклим» [2, с. 40], «чаша небес угорі наче навпіл розколота» [2, с. 51], «стежки небесні - земним не міра», «хлібними крихтами з неба зорі кришаться» [2, с. 57], «та на небі вже видно ворота в рай» [2, с. 82], «а ми розійшлись попрощавшись $і$ зникли / бо небу здалося - усе вже збулось» [2, с. 113], «але моря немає й близько / але неба немає й далеко» [2, с. 288], «і відкрите навстіж небо - неба благість чиста» [2, с. 331].

Отже, у поетичних творах як Тараса Мельничука, так і Юрія Іздрика концепт «небо» справді підтверджує семантичне значення цієї лексеми. Проте, оскільки в поетичному тексті наявна велика кількість тропів, що спричиняє двоїстість сенсів, то в деяких випадках точне семантичне значення встановити неможливо. Також індивідуальні авторські епітети, метафори та персоніфікації забезпечують особливий ідіостиль автора та його поетичну картину.

\section{Лiтература:}

1. Великий тлумачний словник сучасної української мови (з дод. і допов.) / уклад. і гол. ред. В. Т. Бусел. Київ : Ірпінь : ВТФ «Перун», 2005.1728 с.

2. Іздрик Ю. Ліниві і ніжні. А-БА-БА-ГА-ЛА-МА-ГА, 2018. 352 с.

3. Попова 3., Стернин И. Когнитивная лингвистика: монография. Москва : АСТ: «Восток-Запад», 2007. 314 с.

4. Лаюк М. Художні концепти Тараса Мельничука. Tertium non datur : проблема культурної ідентичності в літературно-філософському дискурсі XIX-XXI ст. : колективна монографія. 2014. С. 220-257.

5. Мельничук T. Юнак милується автоматом. DISCURSUS, 2019. 16 с.

6. Мініч Л. Загальнонаціональні концепти душа, життя, любов, вода, земля в поезії М. Вінграновського. Рідний край. 2010. № 1. С. 101-104.

7. Совтис Н. Вербалізація концепту «небо» в поетичній творчості Л. Венглінського. Наукові записки Національного університету «Острозька академія». Сер. Філологія. 2018. Вип. 2(70), С. 201-303. 


\section{А. О. Тимчук,}

магістрантка Національного університету «Острозька академія»

M. Ocmpoг

anastasiia.tymchuk@oa.edu.ua

\section{МАРКЕРИ НАЦІОНАЛЬНОЇ ІДЕНТИЧНОСТІ В СЛОВОТВОРЧОСТІ МИКОЛИ РАЧУКА}

Лексичний склад мови містить у собі відображення етнічної та культурної спадщини нації. Мова акумулює досвід суспільства, зберігає культуру народу, менталітет нації, підтримує зв'язок із минулими поколіннями. Створення авторських неологізмів - один зі способів передавання думок автора, мислення, поглядів, ставлення до того, що він зображує, індивідуальне бачення подій і явищ.

Авторські лексичні новотвори (далі - АЛН) є «специфічними репрезентантами індивідуально-авторської (нерідко з локальними особливостями) мовної картини світу, що входить до національної мовно-поетичної картини світу, під якою зазвичай розуміється сукупність людських уявлень про світ, експлікованих засобами художньої мови» [3, с. 274].

3-поміж вітчизняних дослідників до проблеми вивчення знаків національної ідентичності в неології зверталися Г. М. Вокальчук, В. В. Жайворонок, М. А. Козловець, Р. Л. Ріжко, О. О. Селіванова, Н. О. Данилюк та ін.

Незважаючи на певні дослідження етнознаків в авторських лексичних новотворах, маркери національної ідентичності у творчості буковинського поета Миколи Рачука, зокрема у збірці «Стослов», досі комплексно проаналізовано не було.

Національна ідентичність - це вид ідентичності, який стосується належності певного народу до окремої нації, що містить спільну культуру, мову, територію та спільні характеристики національного характеру.

Е. Сміт виокремлює такі найголовніші риси національної ідентичності, як територія, спільна історична пам'ять, культура, наявність спільних міфів тощо. [5, с. 24].

Маркерами національної ідентичності (далі - МНI) є мовні одиниці будь-якої частини мови, які містять у своєму структурно-семантичному складі національні асоціативні взаємозв'язки, що фіксують світосприйняття окремої етнічної спільноти та відбивають культурно значущі поняття.

На думку Г. М. Вокальчук, авторські інновації «нерідко містять національно-культурний компонент мовної семантики, репрезентуючи не лише індивідуальне світосприйняття письменника, але й характерні ознаки національного менталітету» [1, с. 1].

О. О. Корнілов уважає, що зовнішній світ і свідомість - це ті два чинники, що породжують національну мовну картину світу [2, с. 112]. В. В. Максимчук вказує, що «поет формує ідіостиль крізь приму власного світогляду, світосприйняття та світовідчуття, беручи за основу локальні й національні мовні стереотипи й етнокультурні елементи» [4, с. 63].

Репрезентантами локальної мовно-поетичної картини світу вважаємо лексичні новотвори поета Буковини Миколи Рачука, які відображають національно визначені поняття, явища та містять у семантиці елементи культурно-історичного й етнографічного погляду.

Проаналізувавши збірку М. Рачука «Стослов», ми зафіксували понад 130 новотворів. Це вказує на те, що в цій збірці автор тяжіє до творення нових слів, формує індивідуальний стиль.

Поет часто звертається до слов'янських міфів, тому зафіксовано значну кількість новотворів із маркерами національної ідентичності, серед яких ми виокремили такі, як: 1) марковані новотвори на позначення стихій і небесних світил; 2) інновації на позначення явищ природи; 3) АЛН із маркерами на позначення рослин; 4) новотвори із зооморфними МНІ; 5) АЛН релігійно-християнської тематики. 
Наявність АЛН на позначення стихій і небесних світил пов'язуємо з язичницькими віруваннями, зокрема поклонінням сонцю, місяцеві, зорям, повітрю, землі, воді, вогню, і їхніми відображеннями в етносвідомості українського народу. У збірці «Стослов» натрапляємо на такі новотвори: сонщесій, зоресяй, зорелам, привітання-обвітрення, вітер-повів, зземлитися, злотополум'я, полум'яно-чисто.

АЛН на позначення явищ природи свідчать про тісний і нерозривний взаємозв'язок людини з природою, підтверджують те, що людина ідентифікує себе завдяки навколишньому середовищу через мову. Зафіксовано такі інновації на позначення явищ природи: грозовомайно, драглистотуманний, шторм-цквал, покотьоло-луна.

3 початку існування людина перебуває в оточенні рослин та тварин. 3 часів язичництва в українців існував культ рослин, тому їм поклонялися як божествам. Зокрема МНІ містять такі новотвори, як к $a$ лина-ивіт, білоглід, ромашка-сонечко. Калина є одним із символів України, а глід та ромашку наділяли магічними силами в народній медицині.

У традиційній культурі тварини - один із провідних засобів відображення уявлень про світ. В аналізованій збірці автор найчастіше вживає новотвори з маркером змія: зиілителька-змія, чорнозмія, обзмійно, це можна пояснити із наявністю змій на буковинських гірських територіях. Проте варто зазначити, що вжиті вони у позитивній конотації.

Релігія в культурній та історичній еволюції української держави має велике значення. Це явище простежуємо в новотворах з релігійно-християнськими маркерами, як-от: ветхозавіття, що стосується Старого Завіту в християнстві, та $n$-Pa-корінь, що містить назву язичницького бога. Наявність цих новотворів на позначення різних релігій свідчить про перехід від язичництва до християнства та залишок певних вірувань і досі.

Отже, у збірці «Стослов» Миколи Рачука засвідчено новотвори з маркерами національної ідентичності на позначення стихій, небесних світил, явищ природи, рослин, тварин та релігійно-християнської тематики, які містять етнічно-культурну конотацію.

Перспективним уважаємо вивчення лексичних новотворів представників інших національних меншин Буковини та авторів, які перебувають в українській діаспорі в частині Буковини, що наразі належить до Румунії.

\section{Першоджерело:}

1. Рачук М. С. Стослов (інтермеццо в обрамленні). Чернівці, 2000. 112 с.

\section{Література:}

1. Вокальчук Г. М. Оказіональні лексичні новотвори в українській поезії XX століття : автореф. дис. на здобуття наук. ступеня д-ра філол. наук : спец. 10.02 .01 «Українська мова». К., 2009. 40 с.

2. Корнилов О. А. Языковие картины мира как производные национальных менталитетов. 2-е узд., испр. и доп. М. : ЧеРо, 2003. 349 c.

3. Максимчук В. В. Авторські новотвори з компонентами на позначення об'єктів невидимого світу (на матеріалі сучасної поезії Рівненщини). Науковий вісник Чернівеиького начіонального університету імені Юрія Федьковича : збірник наукових пращь / наук. ред. Бунчук Б. І. Чернівці : Чернівецький нац. ун-т, 2010. Вип. 509-511 : Слов'янська філологія. С. 274-279.

4. Максимчук В. В. Словотворчість сучасних поетів Рівненщини : монографія; за ред. Г. М. Вокальчук. Острог : Видавництво Національного університету «Острозька академія», 2015. 386 с. (Лексикографічна серія «Українська індивідуально-авторська неографія»; вип. 7).

5. Сміт Е. Національна ідентичність. К.: Основи, 1996. 168 с. 


\section{О. О. Ярошик,}

магістрантка Національного університету «Острозька академія»

M. Острог

oleksandra.yaroshyk@oa.edu.ua

\section{ЛІНГВІСТИЧНІ МАРКЕРИ ВІДДЗЕРКАЛЕННЯ ПСИХОЕМОЦІЙНОГО СТАНУ ГОЛОВНОЇ ГЕРОЇНІ РОМАНУ «ПОКРОВ» ЛЮКО ДАШВАР: ЛЕКСИЧНИЙ РІВЕНЬ}

В останні роки сучасні мовознавці все частіше залучають до дослідження мовних тем категорії психології. Зокрема лінгвісти вводять до своїх праць поняття «емоція», «людська емоційність» як такі, особливості яких досить виразно проявляються в різних за характером мовних засобах. У зв'язку з цим маємо змогу продемонструвати можливість мови віддзеркалювати специфіку людської психіки. Така проблематика новітніх досліджень передусім свідчить про антропоцентричне спрямування лінгвістики XXI сторіччя, що є безпосереднім показником актуальности подібної тематики.

На проблемі мовних засобів, які здатні репрезентувати особливості психоемоційного стану людини, неодноразово наголошено у працях М. Степанюк, Л. Білоконенко, В. Шаховського, М. Гамзюка, Н. Киселюк, І. Пініч, К. Соколової, С. Шабат-Савки, І. Кость.

Мета роботи - виявити лінгвістичні маркери лексичного структурного рівня мови в мовленні Мар'яни Озерової і з'ясувати, вказівку на які емоції головної героїні містить кожна мовна одиниця.

Центральним терміном розвідки $є$ категорія лінгвістичного маркера. Під цим поняттям розуміємо мовну одиницю, виокремлення якої відбувається на різних структурних рівнях мови (лексичному, фразеологічному, морфологічному, синтаксичному), переважно відзначається емоційно-експресивним забарвленням та містить приховану, прямо не сказану, але вкрай важливу інформацію про особливості психоемоційного стану людини, тобто про емоції, які їй властиві в конкретний момент мовлення.

У зв'язку з тим, що мовні одиниці досить часто розглядають як такі, що містять у собі інформацію про людські емоції, у лінгвістиці виникає категорія емотивности. На сьогодні проблемним питанням стало ії ототожнення з поняттям «емоційність». Таке розуміння абсолютно хибне. Досить влучно висловлює свою думку з цього приводу Д. Станко: «емоційність - це здатність людини переживати й виражати свої емоції, емотивність - це властивість мови виражати системою своїх засобів емоційність мовця як факт його психіки...» [2, с. 181]. На основі цього стверджуємо відмінність двох понять і зазначаємо, що емоційність - психологічна категорія, емотивність - лінгвістична.

Під час безпосереднього пошуку та аналізу лінгвістичних маркерів лексичного рівня у мовленні головної героїні Мар'яни Озерової у їх функціюванні було простежено дві тенденції:

1) власна вказівка героїні на специфіку психоемоційного стану через використання лексем, які своїм первинним значенням указують на емоції дівчини (репрезентовані незначною кількістю таких одиниць), наприклад: «-Я поїду, і вони не втримаються купи, розлетяться, як краӥна розвалюється на очах. Страшно. Хтозна, що принесе новий день?..» [1, с. 278]. У поданій мовленнєвій ситуації Мар'яна Озерова не приховує свого стану і зазначає, що їй страшно. Прислівник через первинне значення «відчувати страх, боятися» дає вказівку на емоції страху і тривоги;

2) використання слів, одним із компонентів яких є прихована емотивна семантика. Такі лінгвістичні маркери частотніші, тому виокремлюємо низку підгруп:

- номінація осіб через ненормативну лексику: «- Покидьки! - раптом дзвінко кричить чорним щурам уще розчахнуті двері. - Майдан вас усіх змете! Усіх!» [1, с. 104]. Героїня розгнівана на агресивно налаштованих чоловіків, з якими зустрілася в метро. Коли дівчині вдалося вибратися неушкодженою, вона виплеснула свою злість, що власне виразилося через наявний емотивний складник у лексемі покидьки; 
- номінація частин тіла людини, речей, явищ, що має забарвлення зневажливости: «-Хотинський увесь мій мотлох у сумку увіпхнув, - допетрала раптом. - У лофті й шпильки моєї не лишилося... - почервоніла, наче щойно коханець їй по щоках ляпасів - а на, на» [1, с. 127]. Емоції розчарування, неприємного здивування і гніву водночас виражено через використання зневажливо-забарвлених лексем мотлох на позначення речей дівчини і увіпхнути в значенні «скласти». Мар'яна Озерова врешті починає розуміти, що Хотинський не має до неї жодних почуттів і лише використовує для того, щоб знайти потрібну йому інформацію;

- номінація мовленнєвих процесів: «- Тато ходитиме не тому, щңо Кривошийха щэось ляпнула! Бо не здається» [1, с. 269]. Дівчина не стримує свого гніву, оскільки сердиться на Кривошиїху (жінка має здатність передбачати майбутнє), яка сказала, що Мар'яна ніколи не зможе мати дітей. Вияв злости фіксується через використання в мовленні героїні емотивно маркованої лексеми ляпнути в значенні «говорити якусь нісенітницю; висловлювати певні думки без переконання в їх правдивості» замість, до прикладу, слова сказати, що не є виразником жодних додаткових значень;

- номінація процесів і станів. Особливістю лінгвістичних маркерів цієї підгрупи $є$ їх переносне значення: “Сплю... Вже другу добу поспіль...»- подумала Мар'яна, засинаючи. ... І просинатися не хочу!...» [1, с. 136]. Лексему спати вжито в переносному значенні «не вірити, що певна подія відбувається з тобою». Тут ï використано, щоб передати емоцію радости, адже Мар'яна зустріла людину, яка закохана в неї. Дівчина розуміє, що ці почуття взаємні. Тому головна героїня запевняє себе, що сnиmb, адже не вірить у реальність цієї події;

- характеристика осіб: «Вибачуся! Цілісінький день на мене вбив, светр дав, а я... Вибачуся. Поясню... Ні! Не стану нічого пояснювати і вибачатися - подякую... Може, поцілую божевільного, бо він-ненормальний, чокнутий... класний! Дитина! Намалював собі світ і живе в ньому. Так не буває...» [1, с. 118]. У поданому фрагменті роману Мар'яна кількома прикметниками описує хлопця Ярка, якого випадково зустріла в метро. Зазначимо, що лексеми ненормальний і чокнутий (які на перший погляд мають негативну конотацію) вжито винятково в позитивному значенні «не такий як усі; особливий; здатний відступити від правил». Дівчина не лише характеризує хлопця, а й через власне сприйняття іншої людини демонструє емоції здивування і захоплення;

- номінація абстрактних станів людини: «-Я знаю, чому мені тут так добре, - розповідала Мар'яна Полі телефоном. - Тут родове гніздо Дорошів. А Ярко ж-Дорош...» [1, с. 269]. Головна героїня перебуває в радісному психоемоційному стані, адже дівчині нарешті вдалося зібрати всю сім'ю разом і перебратися до затишного будинку в Дорошівці. Свою емоцію Мар'яна передає через лексему добре, яку вживають на позначення задоволення перебігом життєвих подій. Інтенсивність вираження радости героїні підсилено часткою так;

- етикетні формули: «- Дякую, щзо не лишили без помочі, Кривошиїхо, - прошепотіла» [1, с. 378]. Мар'яна Озерова перебуває в радісному стані, адже Кривошиїха допомогла дівчині народити дитину та зберегти життя немовляти. Тому героїня щиро дякує жінці за допомогу.

На основі нашої розвідки дійшли висновку, що лінгвістичні маркери віддзеркалення психоемоційного стану Мар'яни Озерової формують цілісну систему. Це пояснюємо можливістю виокремлення підгруп маркерів, кожна з яких характеризується своїми особливостями. Вважаємо, що саме проаналізовані мовні одиниці допомогли авторці повною мірою передати емоційність головної героїні.

\section{Література:}

1. Дашвар Л. Покров: роман. 2-ге вид. Харків: Книжковий Клуб «Клуб Сімейного Дозвілля», 2018. 384 с.

2. Станко Д. В. Розмежування понять «емоційність», «емотивність», «експресивність» та «оцінність» у сучасному мовознавстві. Сучасні дослідження з іноземної філології. 2017. Вип. 15. С. 175-183. 


\title{
ГРАМАТИЧНА СТРУКТУРА УКРАЇНСЬКОЇ МОВИ: ТРАДИЦІї І СУЧАСНІСТЬ
}

УДК 811.161.2’367.62

\author{
Н. М. Мединська, \\ доктор філологічний наук, доиент, професор \\ кафедри української мови та літератури, \\ проректор з навчально-методичної роботи \\ Міжнародного економіко-гуманітарного університету \\ імені академіка Степана Дем'янчука, м. Рівне, \\ medynsky.natalia@gmail.com
}

\section{ФУНКЦІЙНА НЕОДНОРІДНІСТЬ ДІЕПРИКМЕТНИКІВ}

Вивчення граматичних одиниць - як синтаксичних, так і морфологічних - у сучасній лінгвістиці полягає в 3’ясуванні їхньої ролі у процесі комунікації. Своєрідно вони представлені, зокрема, формами дієприкметників, що функціонують у реченні як означення або присудки.

У різні історичні періоди побутувало неоднозначне трактування категорійної сутності дієприкметника.

I. Р. Вихованець зробив висновок, що всі концепції зорієнтовані на частину вживань дієприкметника і запропонував свою концепцію, у якій за граматичною ознакою поділив дієприкметник на прикметникові віддієслівні утворення - синтетичні форми дієприкметників, уживані в присубстантивній позиції, і дієслівні утворення - аналітичні форми дієприкметників, що займають дієслівну присудкову позицію. Перші зарахував до класу прикметника як один із різновидів віддієслівних прикметників, другі - до дієслова як різновид аналітичних (аналітичних пасивних) дієслів зі значенням результативного стану [2, с. $146-147,150]$.

У дієприкметників як різновиду віддієслівних прикметників, на його думку, нейтралізовані основні дієслівні категорії часу, способу та особи і збережено лише дієслівну категорію виду, що в морфологічному плані сприяє диференціації сукупності прикметникових грамемних флексій категорій роду, числа, відмінка [2, с. 150].

Похідний характер дієприкметникових утворень засвідчує також те, що вони поєднали як динамічні, так і статичні якісні ознаки. Але проблему зарахування дієприкметника до класу дієслів чи до класу прикметників та визначення відповідної сфери його функціонування на сучасному етапі лінгвістичної науки остаточно не розв'язано.

Узагальнивши різні підходи дослідників до потрактування статусу, семантичних і граматичних ознак дієприкметника, констатуємо його функційно-семантичне роздвоєння. Синтетичні форми дієприкметників, тобто ті, що вживані в приіменниковій, типовій для прикметника позиції, є виразниками тієї статичної ознаки, яку передають відносні прикметники - ознаки предмета за відношенням до виконуваною ним дією або за властивим чи набутим ним станом, пор.: змарніле обличчя, задубілі пальйі, посохла трава, випрасуваний одяг, засніжені полонини, виважений кочторис, начищене взуття, відлитий посуд. Таку ознаку I. Р. Вихованець кваліфікував як нерозчленовану семантику стану, яка відрізняється від семантики стану дієслова, що є для нього хоч і периферійною, але має процесуальний характер. Дієприкметникові, навпаки, властива нівеляція ознаки процесуальності і перетворення іiі на віддієслівну ознаку предмета $[1$, с. $131 ; 3$, с. 286]. Аналітичні форми дієприкметників, що зараховані до сфери дієслова - підкласу дієслів стану, бо вони виконують типову для нього формально-синтаксичну функцію присудка, куди їх переводять дієслівні власне- та невласне-зв'язки, передають у пасивних конструкціях значення результативного стану, що є наслідком виконаної дії, яку виражали вихідні для таких дієприкметників дієслова [3, с. 287 - 288]. Напр.: ...Софія Київська закладена не 1037, а 1017 року («Тиждень», 2017). 
Із семантичною неоднорідністю дієприкметників корелюють їхні граматичні ознаки. Морфологічні категорії часу і способу, що визначають граматичну специфіку дієслова як самостійної частини мови, синтетичним формам дієприкметників не властиві у зв'язку з їхнім використанням у прикметниковій позиції. За визначенням I. Р. Вихованця, такі дієприкметники зберігають лише часову співвіднесеність 3 дієслівними формами теперішнього та минулого часу [1, с. 129]. Із власне-дієслівних морфологічних категорій дієприкметникам властива лише категорія виду, але иї мають й інші, пов'язані 3 дієсловом одиниці - прикметники, віддієслівні іменники та ін. [1, с. 178; 2, с. 118]. Натомість синтетичні форми дієприкметників, уживаючись у приіменниковій позиції, набули від опорного іменника прикметникових, синтаксично залежних морфологічних категорій роду, числа й відмінка, пор.: розквітлий сад, забудована територія, застелене ліжко, викарбувані слова.

Аналітичним дієприкметниковим формам надали визначальних для дієслова морфологічних категорій часу та способу дієслівні зв'язкові компоненти, які перевели їх у присудкову позицію, унаслідок чого були нейтралізовані прикметникові несамостійні морфологічні категорії роду, числа та відмінка, пор.: Закон підписаний; Закон буде підписаний; Назва забута; Назва була забута; Звернення поширене: Звернення буде поширене; Було б поширене звернення.

\section{Література:}

1. Вихованець I. Р. Частини мови в семантико-граматичному аспекті: монографія. Київ: Наук. думка, 1988. $256 \mathrm{c}$.

2. Вихованець І. Р. Основні питання морфології. Іменник. Прикметник. Числівник. Займенникові слова. Іван Вихованеиь, К. Г. Городенська. Теоретична морфологія украӥнської мови: Акад. граматика укр. мови. Київ: Унів. вид-во «Пульсари», 2004. С. 7-216.

3. Городенська К. Г. Дієслово. Прислівник. Іван Вихованеиь, К. Г. Городенська. Теоретична морфологія української мови: Акад. граматика укр. мови. Київ: Унів. вид-во «Пульсари», 2004. С. 217-325. 


\section{I. Д. Шмілик,}

викладач кафедри украӥнської мови

НУ «Львівська політехніка», м. Львів

shmilykira@ukr.net

\section{ВАРІАНТНІ ФОРМИ ДАВАЛЬНОГО ВІДМІНКА ІМЕННИКІВ У ПОЕЗІЇ КАМЕНЯРА}

Українська мова багата на варіантні форми, які з різних причин знаходять або знаходили в минулому неоднакове відображення в різних стилях літературної мови. Використання морфологічних варіантів надає мові милозвучності - важливої ознаки художньої літератури й особливо поезії, що зумовлено потребами віршування.

Починаючи з кінця XIX ст., I. Франко працював над утвердженням української літературної мови в Галичині. Поряд із формами, характерними для мовлення тогочасних галичан, поет використовував також і «східні» форми, тобто прагнув знайти найкращий варіант.

Мета наукового дослідження - виявити й проаналізувати всі можливі варіантні форми давального відмінка однини іменників у поезії Каменяра. Джерельною базою слугували лише прижиттєві видання поетичних творів I. Франка: «3 вершин і низин» (1887, 1893), «Зівяле листє» $(1896,1911)$, «Мій ізмарагд» (1898), «Давнє і нове» (1911), «Із днів журби» (1900), «Semper tiro» (1906). Тема є актуальною, оскільки морфологічні особливості вживання іменникових форм відображають епоху становлення української літературної мови кінця XIX - початку XX ст.

В сучасній українській мові нормативним є вживання варіантних флексій -овi (-eвi) та $-\boldsymbol{y}(\boldsymbol{r})$ в давальному відмінку однини іменників чоловічого роду II відміни, окрім іменників на -ів (-їв), -ов, -ев (-є8), -ин [7, с. 118-119]. Ці закінчення історично походять від іменників, що належали до різних основ. Флексію -y мали іменники колишніх основ на -о-, -jo-, які утворювали найбільший за обсягом клас іменників староукраїнської мови; закінчення -ові (-еві) розвинулися з давньої флексії -ови, яку мали

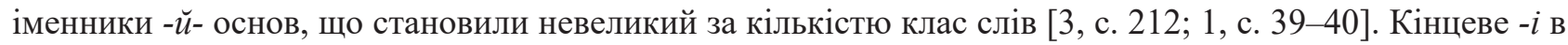
закінченнях -ові (-еві) з'явилося під впливом іменників типу руиі, нозі $[1$, с. 40]. Зауважмо, що в староукраїнській мові іменники чоловічого роду з основою на -о- могли приймати закінчення іменників

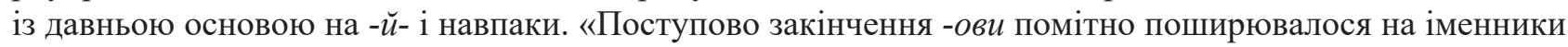
чоловічого роду з основою на -о-, а також на іменники з іншими основами. Уже в українських грамотах $\mathrm{XIV}-\mathrm{XV}$ ст. закінчення -ови в іменниках чоловічого роду трапляється частіше, причому вже не тільки в іменниках - назвах істот, а й у назвах неістот» [3, с. 212]. На сьогодні флексію -y(-ю) «найпослідовніше зберігають східнополіські говори, меншою мірою - південно-східні та карпатські; флексія -ови(-еви) $\epsilon$ типовою для південно-східного наріччя, а також для переважної більшості південно-західних говорів» [8, c. 242].

Українська мова кінця XIX - початку XX ст. фіксує теж варіантні форми цих іменників. С. Смаль-Стоцький та Ф. Гартнер у «Граматиці руської мови» (1914) вказували на певні особливості відмінювання в західноукраїнському та східноукраїнському варіантах мови в іменниках у формі давального відмінка: «...відм. 3 одн. кінчить ся правильно на -ови (на Українї -ові). Окрім того подибуєть ся деколи, особливо під впливом церкви, закінченє -y: Богу, духу (побіч Богови, духови)»; «на -еви, -єви (на Україні -еві, -єві): учителеви, добродієви» [4, с. 67]. Натомість Є. Тимченко вказав, що «датив одн. має закінчення -ові (-еві) та -y. Пануюча форма на -ові (-еві); кінцівка -y вживає ся переважно при збігу двох дативів, напр. пану Иванові» [6, с. 96]. В. Сімович у «Граматиці української мови для самовчання та в допомогу шкільній науцї» (1919) наголошував, що «давальний відмінок однини має правильне закінчення -ові», однак зазначав, що «галицька й подільська форма - -ови, у мнякїй відміні - -еви» [2, с. 148]. Відповідно вживання варіантних закінчень давального відмінка однини іменників II відміни в 
прижиттєвих поетичних творах I. Франка відображає процес їхнього розвитку. Отож проаналізуємо ці варіантні форми.

В іменниках - назвах істот чоловічого роду активно функціонують обидві флексії -ови (-еви) та -y:

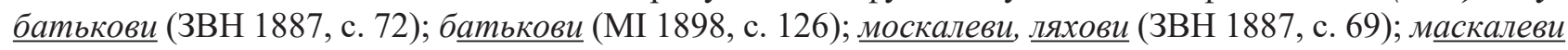
(MI 1898, с. 144); стрільцеви (MI 1898, с. 76); сусідови (MI 1898, с. 88, 89); хозяїнови (MI 1898, с. 99); nастуху (MI 1898, 80); господарю (ІДЖ 1900, 122); хану $i$ султану (ІДЖ 1900, с. 124, 126); товаришу (ЗВН 1887, с. 71). Варіантні флексії є й у власних назвах, однак переважають форми на -y: В.Щуратови (MI 1898, с. 18); Максимови (ІДЖ 1900, с. 38); Миколі Лисенкови (ІДЖ 1900, с. 109); Антошкови П. (ST 1906, с. 89); Олександру (МІ 1898, с. 112); Івану (ІДЖ 1900, с. 97); Есфігмену, Ксеропотаму, Зографу, Павлю (ІДЖ 1900, с. 75, 77); Григорію (ST 1906, с. 40); Куперяну (ST 1906, с. 58).

У досліджуваних поезіях спостерігаємо наявність варіантних форм у межах однієї лексеми: иареви (ЗВН 1887, с. 129), ияареви (MI 1898, с. 82) // ияарю (MI 1898, с. 109); попови (3ВН 1887, с. 120)// nony (ЗВН 1887, с. 114); народови (MI 1898, с. 142)// народу (MI 1898, с. 148); Богови (MI 1898, с. 92) // Богу (ЗЛ 1896, с. 102). Також у межах однієї поезії виявлено варіантні форми -ієви та -ію: соловієви // соловію $(3 В Н 1887,12)$. Фіксуємо сплутування флексій -еви/-ови в лексемі вуж: Не міркуючи богато люто вдарив чоловік, і вужеви неборащі до Дрихітки хвіст відсїк (ІДЖ 1900, с. 120); А постав но край нори вужови знов молока (ІДЖ 1900, с. 122).

Зауважмо, що в поетичних творах фіксуємо одночасно обидва варіанти ще й тоді, коли слід уникнути одноманітних закінчень на місці збігу кількох форм давального відмінка: Се не божий шлях верстаєи, А дияволови служиш, майстру гордощчів, щзо Богу рівним бути забагав (ІДЖ 1900, с. 104).

Вибір закінчення -ови чи -y іноді залежить і від віршованих потреб (богослови-ослови, стану-пану): Гуманний будь, не так як богослови, щзо надприродним ліктем довг свій мірять, льву такають, а гримають ослови (ST 1906, с. 108); В Бразилї̈ царем я хлопським стану, там жиду доступу не дам ні $\underline{n a н y}$ (MI 1898, с. 156). Іменники-назви неістот чоловічого роду II відміни в давальному відмінку теж мають варіантні флексії -ови (-еви) та -y, напр.: огневи (MI 1898, с. 48); кіниеви (MI 1898, с. 96); кінию (ІДЖ 1900, с. 113); гніву (ІДЖ 1900, с. 121). Натомість в іменниках - назвах неістот середнього роду II відміни фіксуємо лише флексію -у: оку (ЗВН 1887, с. 32); злу й добру (MI 1898, с. 46); серию (MI 1898 , с. 75); полю (ST 1906, с. 87) тощо.

Отже, у проаналізованих творах I. Франка виявлено певні особливості вживання варіантних форм давального відмінка однини іменників. Основною причиною такої варіантності є, на нашу думку, відсутність загальноприйнятого правопису у кінці XIX - на початку XX ст., а також потреби версифікації - необхідність дотримуватися відповідного ритму і рими, милозвучності поезії.

\section{Джерела:}

ЗВН 1887 - Франко І. 3 вершин і низин: Збірник поезій. Львів: [Б.в.], 1887. 251 с.

ЗВН 1893 - Франко І. 3 вершин і низин: Збірник поезій. Друге, доповн. виданє. Львів, накладом Ольги Франко, 1893.468 с.

ЗЛ 1896 - Франко І. Зівяле листє. Лірична драма. Львів: 3 друкарні Інст. Ставропігійського, 1896. 112 с.

ЗЛ 1911 - Франко І. Зівяле листє. Лірична драма. Друге виданє. Київ: Друкарня «С.В. Кульженко», 1911. 109 с.

MI 1898 - Франко I. Мій ізмарагд: поезії. Львів: 3 друкарні нар. Ст. Манєцкого і Спілки під зарядом В. Годака, $1898.174 \mathrm{c}$.

ДН 1911 - Франко І. Давнє й нове. Друге побільшене виданє збірки «Мій Ізмарагд». Львів: Накладом українсько-руської видавничої спілки, 1911. 263 с.

ІДЖ 1900 - Франко І. Із днів журби: поезії. Львів: 3 друкарні В. Шийковського, 1900. 127 с.

ST 1906 - Франко I. Semper tiro: Збірка поезій. Львів: накладом україн.-руської видавничої спілки, 1906.135 с.

\section{Лiтература:}

1. Матвіяс І. Курс сучасної української літературної мови. Морфологія. К.: Радянська школа, 1962.164 с.

2. Сімович В. Граматика української мови для самовчання та в допомогу шкільній науцї. Друге видання з одмінами й додатками. Київ-Ляйпціг: Українська накладня, 1919. 584 с.

3. Денисюк В. Варіантні форми давального відмінка іменників як мовний лакмус писемних пам'яток XVIXVIII ст. Філологічний часопис. 2016. Вип. 1(7), С. 28-37.

4. Смаль-Стоцький С., Гартнер Ф. Граматика української мови. Вид. 3. Відень: Накладом власним, 1914. 202 с. 
5. Тараненко І. Й. Іменник Безпалько О. П., Бойчук М. К., Жовтобрюх М. А., Самійленко С. П., Тараненко І. Й. Історична граматика української мови. К.: Радянська школа, 1962. С. 182-240.

6. Тимченко Є. Украінська граматика. К.: друкарня ун-ту св. Володимира, 1917. 168 с.

7. Український правопис. К.: «Наукова думка», 2019. 391 с.

8. Царалунга I. Варіативність у староукраїнській літературно-писемній мові XIV-XV ст.: монографія. Хмельницький: ФОП Гонта А.С., 2017. 448 с. 


\section{I. Ю. Рабчук,}

аспірантка, викладачка кафедри украӥнської мови і літератури,

Національний університет «Острозька академія», м. Острог

iryna.rabchuk@oa.edu.ua

\section{ЛЕКСИЧНЕ НАПОВНЕННЯ АПОЗИТИВНИХ СИНТАКСЕМ ТЕМАТИЧНОГО ДІАПАЗОНУ «НАВКОЛИШНІЙ СВІТ ЛЮДИНИ»}

Апозитивна синтаксема, як багатоаспектна синтаксична категорія, викликає значне зацікавлення науковців. У більшості досліджень їі аналізують у формально-граматичній (О. Баранник, Б. Ключковський, М. Кобилянська, С. Кротевич, Н. Гуйванюк, І. Слинько та ін.), семантико-синтаксичній (I. Арібжанова, О. Кульбабська, О. Турко (Яцук), Н. Горголюк та ін.) та функційно-стилістичній (Г. Козачук, Л. Костич, О. Марчук, Л. Мацько, О. Остроушко, Л. Підкамінна, Н. Слобода, В. Філінюк та ін.) парадигмах. Щодо специфіки функціювання апозитивеми в семантико-синтаксичній структурі речення визначено, що вона реалізується «при базових предикатах дії, предикатах процесу, предикатах стану, предикатах якості, предикатах власне-локативних та предикатах кількості» [2, с. 359-360], однак в українському мовознавстві залишається досі не дослідженим іiі функціювання при субстанційних синтаксемах. Тому мета нашого повідомлення - схарактеризувати лексичне наповнення апозитивем тематичного діапазону «Навколишній світ людини» при суб'єктних, об’єктних, адресатних, інструментальних і локативних синтаксемах.

Роль апозитивної синтаксеми, що позначає істот-неосіб, предмети, явища, поняття, можуть виконувати як власні назви (оніми), так і загальні (апелятиви). При суб'єктних й об' єктних синтаксемах функціюють апозитивеми-оніми: 1) топоніми: Гора Стрилиця лиса... (В. Шкляр) (при суб'єктних синтаксемах); Треба було прощатися з Двірием, річкою Горинню (П. Кралюк) (при об'єктних синтаксемах); 2) ергоніми: Вивіска «Вампірня» / ясніє ... (Ю. Андрухович) (при суб'єктних синтаксемах); ...а також освятять у Чортополі дерев'яну ичеркву Воскресіння... (Ю. Андрухович) (при об'єктних синтаксемах); 3) хрематоніми: Виступ фольклорного колективу «Золоті дримбарі»... (Ю. Андрухович) (при суб’єктних синтаксемах); ...Середземне море там нагадує совєтський одеколон «Русскій лєс» (С. Либонь) (при об'єктних синтаксемах); 4) зооніми: ...вона, його Зірка, справді поводилася норовисто (В. Шкляр) (при суб'єктних синтаксемах); ...винуватили отаманову кобилу Зірку... (В. Шкляр) (при об’єктних синтаксемах). При локативних синтаксемах фіксуємо такі апозитивеми-оніми: 1) топоніми: ...nослав $y$ напрямку села Грушківки... (В. Шкляр); 2) космоніми: Проходить Сонце крізь сузір'я Лева... (О. Ірванець); 3) ергоніми: ...в готелі «Фйоренца», в неділю увечері - джаз! (О. Забужко); Перший державний бізнес-інкубатор [...] відкрили у Національному центрі «Мала академія наук» (МАН) (УП, 19.02.18); 4) хрематоніми: Майбутніх біографів відсилаю до Неборакового вірша "Янівський цвинmap»... (Ю. Андрухович). При адресатних синтаксемах функціюють апозитивеми-оніми: 1) теоніми: Дякую Тобі, Божее, щзо дав нам тіло! (О. Забужко); 2) ергоніми: ОРГКОМІТЕТ висловлює щзиру вдячність і глибоку відданість спонсорам свята: кооперативу "Металіка» [...], спільному підприємству «Інтерсекс»... (Ю. Андрухович). При інструментальних синтаксемах натрапляємо на хрематоніми, наприклад: ...яка [американська військова льотчиия] була нагороджена медаллю за відвагу «Пурпурове серце» та званням Герой війни (УП, 08.02.18).

У наведених конструкціях між означуваним словом й власне апозитивною синтаксемою-онімом виникають відношення номінації, а між означуваним словом і напівпредикативною апозитивною синтаксемою-онімом - номінації й уточнення. Водночас використання в ролі апозитивем відомих, близьких читачеві онімів (наприклад: місто Львів, містечко Париж, табір «Артек» тощо) створює своєрідний стилістичний ефект нашарування авторських і читачевих смислів, особистих асоціацій, емоцій, сприяє більшому зануренню реципієнта у світ тексту. 
Найбільш численні серед апозитивем-апелятивів ті, що, функціюючи при суб'єктних й об'єктних синтаксемах, характеризують істот-неосіб, предмети, явища, поняття: 1) за призначенням, функцією: Iнститут вивчення війни $і$ RAND, ще один американський аналітичний центр, у свойх доповідях дійшли висновків... (Апостроф, 13.03.18); (при суб'єктних синтаксемах); ...щоб чіпляти колисанку-орелю (В. Шкляр) (при об’єктних синтаксемах); 2) за якісною ознакою або станом, зовнішньою ознакою: ...коли зненацька починається дощ-раптівка (М. Матіос) (при суб'єктних синтаксемах); Я любив [...] милуватися величним собором, [...], иерквою-ротондою біля нього... (П. Кралюк) (при об'єктних синтаксемах); 3) за видовими ознаками: трясе непал і шамбала в опалі / проблеми навіть в господа-отця... (Ю. Іздрик); Боти-юристи - ие реальність (УП, 14.02.18) (при суб’єктних синтаксемах); ...Hе складав би віршики-пісні (В. Симоненко); ...решта: / приготування кави-запис витрат / споглядання пагорбів - і риб-летунів,.. (В. Махно) (при об’єктних синтаксемах); 4) за зовнішньою, внутрішньою чи асоціативною подібністю з іншими предметами, явищами, істотами-неособами: наше літо-слимак перевозить свій дім / у прозорій невидимій мушлі... (Ю. Іздрик) (при суб'єктних синтаксемах); ... інші [...] вмокали в загуслу / від алкоголю та наркотиків кров / - ииганську голку -/хоботок сонної бджсоли (В. Махно) У нього й справді був ніс-долото... (В. Шкляр) (при об’єктних синтаксемах).

За нашими спостереженнями, друга за чисельністю - група апозитивем-апелятивів, що функціюють при локативних синтаксемах і характеризують істот-неосіб, предмети, явища, поняття: 1) за призначенням, функцією: ...ніхто з чоловіків у яму-сміттярку не зазирав... (М. Матіос); 2) за якісною ознакою або станом, зовнішньою ознакою: Цей сон тримає першість серед мойх снів-жахастиків... (Л. Денисенко); 3) за видовими ознаками: Четвірка заморських коней у вагоні-товарняку й він, Яків, серед них... (В. Лис); ...оси поскидалися роями з груши-диюк до Марї̈ої возниці (М. Матіос); 4) за зовнішньою, внутрішньою чи асоціативною подібністю з іншими предметами, явищами: Вселенська тиша стоїть над горами-долами (М. Матіос); В очах-тунелях приятеля - безпросвітна ніч... (В. Неборак). Функція характеризації істот-неосіб, предметів, явищ, понять за зовнішньою, внутрішньою чи асоціативною подібністю з іншими предметами, явищами, істотами-неособами поєднується з художньо-образною, адже апозитивна синтаксема у таких конструкціях стає джерелом творення тропеїчних значень.

На периферії перебуває вживання апозитивем-апелятивів при інструментальних синтаксемах: ... вельми погрозливо ворушила на ходу своїми патлами-зміюками (І. Карпа); Очі неїни паволокою-туманцем затягнуті... (В. Лис).

Хоч «лексичне наповнення адресатної синтаксеми передбачає обов'язкову номінацію людей, рідше тварин» [3, с. 193], уживання назв предметів у цій позиції- - окрема, й апозитивем-апелятивів - можливе за умови метафоризації, персоніфікації понять [3, с. 193], наприклад: ...Свої багатства осені-вдові / Передає безпечно і невміло (В. Симоненко).

Отож, аналіз лексичного наповнення апозитивних синтаксем тематичного діапазону «Навколишній світ людини» засвідчив, що вони можуть бути виражені як власними назвами (онімами), так і загальними (апелятивами), і функціюють при всіх типах субстанційних синтаксем, хоча найбільш частотне їх уживання при суб'єктних, об'єктних і локативних синтаксемах.

\section{Лiтература:}

1. Вихованець I. Р. Граматика української мови. Синтаксис : підручник. Київ : Либідь, 1993. 368 с.

2. Кульбабська О. В. Вторинна предикація у простому реченні : монографія. Чернівці : Чернівецький національний університет, 2011. $672 \mathrm{c}$.

3. Межов О. Г. Типологія мінімальних семантико-синтаксичних одиниць : монографія. Луцьк : ВНУ ім. Лесі Українки, 2012. 464 с. 


\section{В. М. Кухарська,}

магістрантка Національного університету «Острозька академія»,

M. Острог

viktoriia.kukharska@oa.edu.ua

\section{ДО ПРОБЛЕМИ ПРИЙОМІВ ПЕРЕКЛАДУ НЕОЛОГІЗМІВ}

Мова преси найдинамічніша серед інших систем сучасної мови. Не секрет, що саме в ЗМІ найбільше та найгрунтовніше виявлені процеси, які характеризують мову як організм, що постійно перебуває в розвитку. Тому вагоме значення у ЗМІ мають неологізми. Вивчення цього шару лексики неодноразово ставало предметом дослідження вітчизняних науковців, зокрема в цій царині працювали Д. В. Мазурик, Г. В. Микитів, С. В. Шевченко, М. В. Бойчук, О. А. Стишов, О. Ю. Арешенкова, Н. М. Фіголь та інші.

Із активним процесом європеїзації українського суспільства виникає потреба перекладу української мови, задля інформування про суспільні відносини і зміни. Над питаннями проблем перекладу працюють такі вчені, як В. І. Карабан, Ж. А. Голикова, С. С. Максимов, Л. Л. Нелюбин, О. І. Чередниченко, I. О. Гальперін та інші.

Наукові доробки з цього питання переважно окреслюють особливості перекладу із англійської, німецької, французької мов на українську, а не навпаки. Тому актуальним постає питання перекладу й інтерпретації неологізмів української мови на світовому рівні.

Неологізми слугують, з одного боку, для номінації нових чи ще не названих понять, реалій, а з іншого - для заміни попередніх найменувань новими, до мовної економії, уніфікації номінативних моделей тощо [4, с. 22].

Непростим завданням для перекладача постає переклад неологізмів, адже ці лексеми не зафіксовані в словниках, тому не мають загальноприйнятого значення. Перекладач вперше, натрапивши на неологізм, ідентифікує його як поняття, що потрібно витлумачити. Цей процес вимагає не лише досконалого володіння мовою перекладу, щоб встановлювати значення інновації як за їі структурою, так і за наявністю варіативних або синонімічних форм, а й орієнтування в суспільному процесі задля встановлення контексту.

Науковець Т. Данкевич виокремлює два етапи перекладу неологізмів англійської мови на українську: а) 3'ясування значення неологізму; б) власне переклад засобами української мови, а саме: транскрипція, транслітерація, калькування, описовий переклад, пряме включення [1, с. 342].

Козаченко І. вважає «опис та пояснювальний описовий переклад найпоширенішим способом передачі нових утворень іншою мовою». Його здійснюють шляхом пояснення суттєвих елементів неологізму. Його часто порівнюють із тлумаченням слова [3, с. 166].

Транскрибування та транслітерацію Ю. Шкуліпа об’єднує терміном «транскодування», визначаючи його як «передачу звукової чи графічної форми слова мови оригіналу за допомогою літер мови перекладу» [5, с. 92].

Ще один варіант перекладу неологізмів - калькування. Цей спосіб полягає в заміні компонентів, морфем чи слів (у випадку стійких словосполучень), одиниці оригіналу - їх лексичними відповідниками в мові перекладу [2, с. 178] .

Популярним останнім часом стає спосіб прямого включення, який використовує написання слова в оригінальній (початковій) формі. Зрозуміло, його використовують, коли жоден із вищезазначених методів не передає необхідно значення поняття, що перекладають [3, с. 167].

Кожен із запропонованих прийомів не є універсальним і не забезпечує ідеального перекладу. Під час роботи з неологізмами слід враховувати не лише тип слова, а й контекст, у якому це слово вико- 
ристовують, щоб точніше передати суть неологізму, який перекладають. Важливим фактором є також збереження стилістичних й емоційних характеристик.

\section{Література:}

1. Данкевич Т. Переклад авторських неологізмів в англійській мові. Мова і культура. 2014. Вип. 17, т. 3. C. $341-346$.

2. Драбов Н. До питання перекладу англійських неологізмів. Актуальні питання гуманітарних наук. 2015. Вип. 13, С. 176-181.

3. Козаченко І. Особливості перекладу неологізмів англійської мови. Науковий вісник Міжнародного гуманітарного університету. Сер.: Філологія. 2014. № 25. Том 2. С. 166-168.

4. Тараненко О. О. Енциклопедія українська мова. URL: http://litopys.org.ua/ukrmova/um54.html (дата звернення: 29.02.2020).

5. Шкуліпа Ю. С. Основні способи перекладу неологізмів публіцистичного стилю з англійської мови українською. Актуальні проблеми філології. Матеріали V Міжнародної науково-практичної конференції. Херсон : Видавничий дім «Гельветика», 2017. С. 91-93. 


\title{
КОМУНІКАТИВНИЙ ВИМІР ФУНКЦІЮВАННЯ \\ УКРАЇНСЬКОЇ МОВИ
}

УДК 373.5.016:811.161.2

\author{
О. Д. Кулик, \\ доктор педагогічних наук, \\ професор кафедри украӥнської лінгвістики і методики навчання \\ ДВНЗ «Переяслав-Хмельницький державний педагогічний \\ університет імені Григорія Сковороди», \\ м. Переяслав-Хмельнииький, \\ olenakulyk@gmail.com
}

\section{РОЛЬ ЧАСТКОВОГО СЛОВОТВІРНОГО АНАЛІЗУ ТЕКСТУ В СТИМУЛЮВАННІ МОВЛЕННСВОЇ РЕФЛЕКСІЇ УЧНІВ}

Словотвірний аналіз тексту чи його фрагментів дає можливість учням поєднати знання, отримані під час вивчення розділів «Будова слова», «Словотвір», із практичною діяльністю під час вивчення інших розділів шкільного курсу української мови. Варто зауважити, що словотвірний аналіз тексту не передбачає морфемного чи словотвірного аналізу слів, не є чітко структурованим, залежить від особливостей функційного стилю мовлення та індивідуально-авторського бачення світу. Під час словотвірного аналізу тексту варто: визначити функції морфем, що беруть участь у формально-семантичній організації тексту, з'ясувати роль повторів морфем, їхню синонімію, антонімію, омонімію в організації тексту; визначити, чи наявні в тексті лексеми із загальним словотвірним значенням (наприклад, абстрактна ознака, опредметнена дія, зменшувально-пестливе значення та ін.) та з'ясувати роль їх в організації тексту; визначити слова, утворені морфолого-синтаксичним способом та з'ясувати функції їх у тексті; визначити оказіоналізми, указати спосіб їхнього творення, з'ясувати роль в організації тексту; визначити жартівливе членування і псевдочленування слів, з'ясувати роль в організації тексту; визначити інші словотвірні явища в тексті та з'ясувати роль в його організації. Важливо вказати учням на те, що конкретний аналізований текст може містити лише окремі з вищезазначених словотвірних явищ, однак одне явище може виконувати різні ролі в організації тексту. Розглянемо роль часткового словотвірного аналізу тексту в стимулюванні мовленнєвої рефлексії учнів на прикладі фрагменту 3 казки Л. Керолла «Аліса в Країні Див».

-Прочитайте текст. Виконайте його частковий словотвірний аналіз.

\section{I доки Миша говорила, Аліса не переставала гадати, до чого тут мищачий хвіст. \\ Тож історія Миші в ї̈ уяві прибрала десь такого звивистого вигляду:}

\author{
Cmpis \\ Мурко мишку \\ s xami i noyas \\ ӥй казати: «Я тебе \\ позиваю, ходім \\ мишко, на суд; \\ відкладать \\ не годить- \\ ся: будем \\ нині су- \\ диться,
}




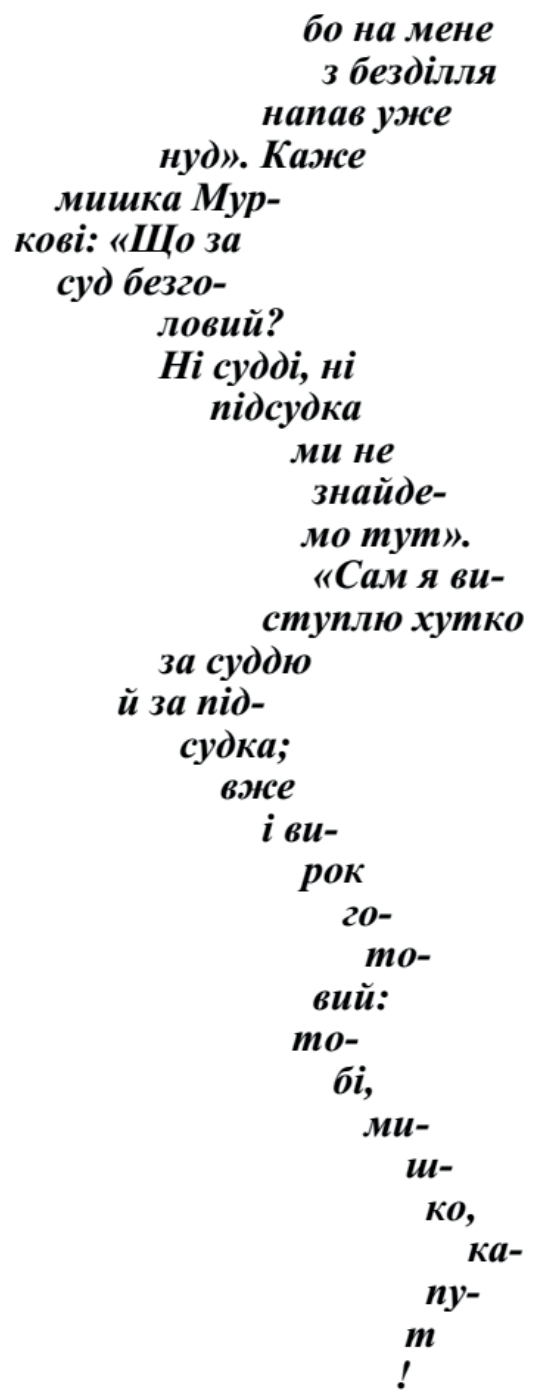

Далі вчитель підводить учнів до висновків, що:

для створення «фігурності», тобто відповідного малюнка у візуальному сприйнятті вірша

для посилення жвавості вірша

для підтримки рими і чіткого ритму вірша

для створення комічного ефекту aвтор використав жартівливе членування (поділ на склади за правилами) та псевдочленування (навмисне порушення правил складоподілу) слів

автор використав суфіксальні повтори у словах годиться - судиться

автор використав співзвучність морфем у словах хаті казати; Муркові - безголовий; підсудка (підсудок) - хутко, причому в усіх випадках морфеми не $\epsilon$ чіткою римою, однак співзвучні настільки, що рима стає навіть ефектною автор використав співзвучність морфем у лексемах слівослів - вузлів. 
Аналізуючи вірш, учні з’ясовують, що не розуміють значення слова «підсудка / підсудок» (а отже, й значення морфем, що до нього входять). Для цього вони мають звернутися до словника, визначити семантику слова, приналежність до певної частини мови, морфемний склад, аж потім робити висновки. Окрім того, в тексті є слово «нуд», значення якого також невідоме учням. Значення не можна з'ясувати 3 контексту, бо слово могло утворитися як від «нудьга», так і від «нудота», потрібно знову звернутися до словника, потім зробити висновки, з якою метою автор використав «непопулярне» слово «нуд».

У процесі роботи вчитель обов'язково має наголосити на тому, що аналіз словотвірних особливостей будь-якого тексту не є усталеним, єдино можливим: окремі частини цього аналізу можна варіювати, уточнювати - інтерпретація мовної організації тексту завжди суб'єктивна як з погляду автора, так і того, хто його сприймає. Це уможливлює учнів почуватися вільно, невимушено, зміщувати акценти 3 «я цього не знаю, не вмію, не зроблю так, як цього очікує вчитель» на «я можу виконати це завдання, однак варто поглибити рівень знань для того, щоб виконати його краще».

Як бачимо, навіть фрагментарний словотвірний аналіз тексту спонукає учнів до рефлексії: спочатку мовної - самоаналіз (що я знаю про словотворення, словотвірну організацію тексту), самооцінка (текст складний / нескладний, значення окремих слів відоме / невідоме, графічне його оформлення зрозуміле / незрозуміле; чи можу я незрозуміле «переформатувати» в зрозуміле, яким чином), самопроектування (для того, щоб виконати завдання, я маю попрацювати зі словниками, за потреби, попросити допомоги вчителя, з'ясувати значення невідомих слів, усвідомити роль графічного оформлення тексту, порушення автором правил складоподілу); потім - мовленнєвої: самореалізація (на стадії самореалізації мовна рефлексія переходить у мовленнєву, оскільки учень виконує завдання внутрішньо, а потім здійснює спробу його вербалізувати), самоконтроль (результати виконаного завдання повідомляють вчителеві (усно чи письмово), з'ясовують правильність / неправильність / варіативність висновків, здійснюють пошук та виправлення помилок, удосконалення вмінь і навичок словотвірного аналізу тексту), що врешті сприяє розвиткові мовлення учнів під час навчання словотвірної системи української мови.

Таким чином, мета мовної та мовленнєвої рефлексії в процесі вивчення учнями словотвірної системи української мови полягає: 1) під час сприймання текстів - в інтерпретації словотвірних засобів, використаних автором висловлення; 2) під час продукування текстів - в пошукові «когнітивного ключа» до вирішення завдання: рефлексіюючи, учень усвідомлює, що ті чи ті словотвірні засоби уможливлюють / унеможливлюють його вирішення; критично осмислює наявні в пам'яті та мовленнєвому досвіді; добирає, на його думку, найбільш вдалі; висуває припущення; приймає інтуїтивне рішення щодо використання тих чи тих словотвірних засобів; логічно обгрунтовує їх; реалізує у висловленні.

\section{Література:}

1. Кулик О. Д. Мовленнєвий розвиток учнів 5-9 класів закладів загальної середньої освіти в процесі навчання словотвірної системи української мови: дис. д-ра пед. наук. спец. 13.00.02 / Київський університет імені Бориса Грінченка. Київ, 2019. 542 с.

2. Кулик О. Д. Мовленнєвий розвиток учнів основної школи в процесі вивчення словотвірної системи української мови: монографія. Київ: Інтерсервіс, 2018. 444 с.

\section{Джерела ілюстративного матеріалу:}

1. Керолл Л. Аліса в Країні Див. Аліса в Задзеркаллі / пер. з англ.: текст В. Корнієнко, вірші М. Лукаш Київ: А-ба-ба-га-ла-ма-га, 2006. 264 с. 


\section{Л. М. Овсієнко,}

доктор педагогічних наук, професор кафедри української мови

Київського університету імені Бориса Грінченка,

м. Kü̈в,

l.ovsiienko@kubg.edu.ua

\section{ТЕКСТ У КОМУНІКАТИВНОМУ ВИМІРІ}

Різноаспектне дослідження тексту зумовлене прагненням науковців схарактеризувати його як багатопланову систему, глобальне явище, цілісний засіб комунікації.

У сучасній лінгвістиці (що враховує лінгвістичні аспекти породження і сприймання тексту) він $є$ продуктом, створеним мовною особистістю й адресованим їй. До того ж у тексті реалізується антиномія - системність / індивідуальність, без якої зміст тексту не може бути пізнаним, а отже - буде мертвим. У науковому полі лінгвістики досліджуване поняття функціонує як багатогранний феномен, тому не існує єдиного його розуміння і визначення. Більшість учених, оперуючи цим терміном, уникають його формулювання як універсальної мовної одиниці або ж тлумачать текст лише з урахуванням головних ознак, критеріїв, структури, типології, проблем породження і сприймання.

За комунікативного підходу текст розглядається як мовний феномен, що перетворюється у принципово нове ціле внаслідок з'єднання окремих членів мовної структури; це деяка система комунікативних елементів (зв'язна і повна послідовність знаків або образів), функціонально об'єднаних у єдину замкнену ієрархічну семантико-смислову структуру загальною концепцією чи задумом [2, с. 75$]$.

В. Одинцов наголошує на тому, що текстом $є$ «...певна 3 функціонально-смислового погляду упорядкована група речень або їх аналогів, які завдяки семантичним і функціональним взаємовідношенням елементів $\epsilon$ завершеною смисловою єдністю» [4, с. 47]. Т. Симоненко зазначає, що текстом $\epsilon$ висловлення, яке $\epsilon$ сукупністю речень та має змістову і структурну завершеність [5, с. 45].

Визначення тексту з позиції критерію комунікативності було запропоноване Ф. Бацевичем шляхом урахування функції тексту як результату спілкування (інтеракції та трансакції), його структурно-мовного складника й одночасно кінцевої реалізації; це структура, в яку втілюється «живий» дискурс після свого завершення [1, с. 122]. Із визначення зрозуміло, що текст постає як проміжний компонент процесу комунікації, одиниця дискурсу, предметно-знаковий стан системи комунікації.

Основними критеріями текстуальності Ф. Бацевич визначає матеріальне втілення, інтенційність, інформативність та комунікативність, які тісно пов'язані між собою й утворюють синтетичну єдність:

-матеріальне втілення (вираженість) - це критерій, що виявляє наявність у тексті обов'язкової матеріальної форми втілення. Однак людина може спілкуватися сама з собою; людське еgо перебуває у постійному діалозі з alter ego; розрив цих зв'язків призводить до серйозних психічних проблем. Безперечно, цей тип комунікативної взаємодії має матеріальні форми втілення, недоступні для інших спостерігачів у прямій формі, що можуть виявлятися у нелінгвальних і паралінгвальних формах з обов'язковою умовою «утілеснення»;

- інтенційність - це умисне створення тексту з певною комунікативною метою, наміром. Побудова тексту, формування його структури здійснюється під впливом авторської інтенції;

- інформативність тексту - його змістове наповнення. Умисно створене та комусь адресоване послання завжди дещо інформативне, навіть тоді, коли закладена в ньому інформація найпростіша і сигналізує лише про наявність того, хто її творить. На противагу тлу, «нетексту», про текст можна говорити лише у випадках наявності наміру (інтенціі), мети його творця та інформативного наповнення. Так, мовлення уві сні, марення текстами вважати не можна, оскільки у них відсутня інтенціональність, скерованість на адресата; 
- комунікативність - це критерій текстуальності, що синтезує в собі розглянуті вище критерії; у найзагальнішому вигляді відображає визначеність повідомлення його функціонуванням в актах спілкування. Це здатність тексту втілювати інтенцію, мету автора, реалізувати своє призначення, функції, які на нього покладаються. Інакше кажучи, текст передбачає наявність інтенціонально скерованих адресанта й адресата, які обмінюються інформативно наповненими текстами [1, с. 42-44].

Щоправда, не можемо беззаперечно погодитись із твердженням Ф. Бацевича про недоцільне вживання в навчальній та методичній літературі слова «текст» у такому контексті: «Ускладнює ситуацію часте нетермінологічне застосування слова «текст» у методиці викладання мови, приміром текст вправи, а також в інших сферах, де йдеться про рух інформації та ії носіїв, наприклад, текст до кадрів фільму, текст партитури опери, текст рухомої стрічки реклами і под.» [1, с. 42], адже в сучасній освітній практиці лексема «текст» активно функціонує як винятково важлива одиниця дидактики, використовувана в умовах реалізації текстоценричного підходу до навчання мови.

Таким чином, у контексті лінгвістичних досліджень текст $є$ продуктом цілеспрямованого мовленнєвого акту, закінченим, об'єднаним спільною метою, змістовим цілим. За прагматичною спрямованістю (знаряддя акту спілкування між адресатом і адресантом із певною метою) текст має свою інформативну наповненість, тобто висвітлює окремий фрагмент мовної картини світу з різним ступенем об'єктивності. Він $є$ комунікативною цілісністю, засобом, основою і результатом комунікативної діяльності особистості/фахівця.

\section{Література:}

1. Бацевич Ф. С., Кочан І. М. Лінгвістика тексту: підручник. Львів: ЛНУ імені Івана Франка, 2016. 316 с.

2. Иванов Д. О., Митрофанов К. Г., Соколов О. В. Компетентностный подход в образовании. Проблемы, понятия, инструментарий. Москва: АПК и ПРО, 2003. 101 с.

3. Овсієнко Л. М. Теоретичні основи навчання лінгвістики тексту студентів філологічних спеціальностей на засадах компетентнісного підходу: монографія. Київ: Інтерсервіс, 2017. 354 с.

4. Одинцов В. В. Стилистика текста. Москва: Наука, 1980. 264 с.

5. Симоненко Т. В. Теорія і практика формування мовнокомунікативної компетенції студентів філологічних факультетів: монографія. Черкаси: Видавництво Вовчок О. Ю., 2006. 328 с. 


\section{С. Романюк,}

доктор габілітований

К. Якубовська-Кравчик,

доктор

М. Замбжицька,

доктор,

кафедра украӥністики, Вариавський університет,

Вариава

k.jakubowska@uw.edu.pl

\section{МОВА І КУЛЬТУРА \\ ЯК НЕВІД'ЄМНІ АТРИБУТИ УКРАЇНСЬКОЇ ТОЖСАМОСТІ. УРАХУВАННЯ КУЛЬТУРОЗНАВЧОГО НАПРЯМУ ПРИ УКЛАДЕННІ ПІДРУЧНИКІВ ІЗ УКРАЇНСЬКОЇ ЯК ІНОЗЕМНОЇ ДЛЯ СТУДЕНТІВ ВНЗ ПОЛЬЩІ}

Відповідно до найновіших підходів у дидактиці іноземних мов, що стосуються врахування культурознавчого підходу під час вивчення чужої мови, так аби учні могли максимально наблизитися до реалій того регіону, де побутує певна мова, були розроблені програми навчання української мови на кафедрі україністики Варшавського університету. Згідно з ними, працівниками, що представляють різні наукові дисципліни (мовознавство, культурознавство, літературознавство), упродовж останніх років укладено низку підручників для вивчення української мови як іноземної. Вибрані праці стали об’єктом аналізу цієї доповіді, а саме - Українською без табу (1), Українською про культуру (2), і додатково - посібник Культура і традииї українців: з минулого в сучасність (3), що містить тексти, пов'язані з реалізацією програми з культурознавства, але доповнений багатьма завданнями на розвиток мови і мовлення. Два з них - Українською без табу (1) й Українською про культуру (2) - призначені для вивчення мови на високому рівні $(\mathrm{C} 1, \mathrm{C} 2)$, а посібник Культура і традиції украйнців: з минулого в сучасність (3) допоможе, перш за все, у вивченні української культури.

Використовувати в програмі філологічної підготовки вищевказані підручники було прийнято не лише для передачі студентові певних знань, що, безсумнівно, надзвичайно важливо, але, перш за все, для мобілізації його до роздумів і подальшого самостійного пошуку інформації про події і факти, порушені у кожному пройденому розділі. Як зазначає Ганна Коморовська, „Лінгвісти та методисти, що аналізують культурний зміст підручників для вивчення іноземних мов у європейських країнах, стверджують [...], що тексти в навчальних матеріалах мають зазвичай, закритий характер, а це означає, що вони несуть інформацію без завдань, які б заохочували до інтерпретації чи дискусії.” [1, с. 29]. Тому перед укладачами стояло завдання запропонувати таку добірку текстів і вправ, які б активізували саме мислення студента. Наприклад, автори вмістили такі вправи: Підготуйте презентацію; Нa основі вибраної наукової літератури підготуйте реферат на тему:.., Значення котрого з оберегів Вас найбільше зачікавило?; Поясніть чому...; Подискутуйте в парах тощо. У таких завданнях не йшлося про відтворення соціокультурного змісту, а саме про підготовку студента до того, аби він свідомо орієнтувався у міжкультурних контекстах Польщі й України.

Згадані вище підручники можна аналізувати з точки зору різних теорій щодо можливості використовувати питання культури в дидактиці іноземної мови. Наприклад, американські науковці Клайд Клакхон і Фредерік Штродтбек вважають, що до найважливіших тем, пов'язаних із навчанням культури, належить природа людини [2]. Приклади розкриття цієї теми використані, зокрема, в Украӥнською без табу (1), в якому найбільшою мірою порушене внутрішнє життя людини, iї психологічні стани, скажімо, в текстах розділу Інтроверт в екстравертому світі, Слухняна, ввічлива, але чи щаслива? Про 
виховання дітей (1), а також в описах різних типів особистості видатних персонажів у підручниках Українською про культуру (2) і Культура і традииї українців: з минулого в сучасність (3). Ще однією проблемою, розкритою Клакхоном та Штродтбеком, було ставлення людини до природи, приклади якої наведені в текстах і завданнях розділів Дивлячись на зорі, Тонемо в смітті. Чи є вихід?, Ми самі створюємо загрозу (1). Порушення зв'язку людини з силами природи, космосом можна відстежити в інших розділах, оскільки це явище часто проявляється в традиціях чи ритуалах, наприклад, святкових - детальніше про це у розділах Рік за роком, У родинному колі (3). Третьою тематичною групою $\epsilon$ поняття часу. Багато текстів із підручника Культура і традищї українщів: з минулого в сучасність (3), зокрема, в розділах Рік за роком, На щастя, на долю, У родинному колі присвячено життю у згоді 3 порами року і плином часу.

В аналізованих працях значну частку матеріалу відведено темі прийняття рішень, що мають значення на перебіг оточуючого світу, а відтак - і на художню творчість. Варто згадати такі блоки як: Життя з піснею, пісня у житті (3), Народне мистеиттво: вибрані аспекти (3), Довкола сакрального (3), Класичні мелодії (3), Українські театральні сиени (3) тощо. Підручник Культура і традиції українців: з минулого в сучасність заохочує студентів вільно спілкуватися про культуру, самостійно знаходити інформацію й інтерпретувати іiі, у цьому допомагають і мовні вправи (в т.ч. на переклад, доповнення, підбір слова тощо).

Особливої уваги заслуговують теми й тексти, присвячені людським взаєминам, наприклад, Слухняна, ввічлива, але чи щаслива? Про виховання дітей (1), Найбільша мрія - стати мільйонером (1), Старість - не радість, горб - не користь (1), Трансплантачія: чи варто бути донором? (1), Дати шанс. Прачевлаштування осіб з інвалідністю (1). У підручнику Украйнською про культуру варто виокремити: Життєві історії, Жіночі долі, Берегиня vs Барбі, У декретну відпустку, Суперники та чемпіони, Еміграиія - жіночого роду. Натомість проблема міжособистісних стосунків у контексті культури розкрита в розділах У родинному колі (3) і Козаџькі інспіращії (3).

Найважливішим $€$ те, що в усіх згаданих працях особливу роль займає мистецтво, як прояв індивідуалізму та діалогу зі світом - у них зображено різні сфери й контексти мистецтва - народна творчість, фольклор, класичнва і сучасна музика, театр тощо. Естетичні враження відіграють велику роль в пізнавальних процесах, вони стимулюють пам'ять, прискорюють засвоєння інформації, викликають додаткові відчуття, змушують думати. Саме про це йшлося укладачам - щоб студент, вивчаючи іноземну мову, глибоко пізнавав культуру того середовища й регіону, в якому вона функціонує.

\section{Література:}

1. Kluckhohn C., Strodtbeck F., Variations in Value Orientations, Row Petersen, Evanston 1961.

2. Komorowska Hanna, Język i kultura w dydaktyce języków obcych [w:] „Kwartalnik Pedagogiczny”, nr 4, s. 27-45.

\section{Джерела:}

1. Jakubowska-Krawczyk K., Romaniuk S., Zambrzycka M., Культура і традиції українців: з минулого в сучасність. Підручник із завданнями, Warszawa 2018, ss. 301.

2. Jakubowska-Krawczyk K., Romaniuk S., Saniewska M., Українською про культуру. Podręcznik do nauki języka ukraińskiego, Warszawa 2018.

3. Romaniuk S., Saniewska M., Українською без табу. Podręcznik do nauki języka ukraińskiego, Warszawa 2017. 


\section{T. Ф. Семанко,}

доктор філологічних наук, професор кафедри журналістики та мовної комунікації

Національного університету біоресурсів і природокористування Украӥни,

м. Kü̈в,

semashko.tat@ukr.net

\section{ЩОДО РОЗМЕЖУВАННЯ ПОНЯТЬ «НАЦІОНАЛЬНИЙ СТЕРЕОТИП» - «ЕТНІЧНИЙ СТЕРЕОТИП»}

Зорієнтування сучасної лінгвістики на врахуванні визначальної ролі людського фактору в усіх галузях людської діяльності, зокрема, й інтерпретація навколишнього світу, призвела до вкорінення в науці про мову комунікативно-функціонального, включно із когнітивним, підходу, що став альтернативою попередньому системно-структурному підходу, і станом на сьогодні $є$ одним із найперспективніших, оскільки дозволяє по-новому поглянути на предмет лінгвістичного дослідження, виявляючи при цьому матеріальну та духовну культуру знака, зумовлює розширення кола мовознавчих досліджень до вивчення складних когнітивних процесів та їхнього впливу на мовне відображення дійсності.

Когнітивна площина досліджень інтегрувала підходи різних наук до вивчення когнітивних структур: від конкретно-чуттєвого образу, картини, схеми, поняття, уявлення до архетипу, концепту, сценарію, фрейму, гештальту, прототипу, стереотипу та ін., як елементів сучасного комунікативного простору, що відомі як складники мовно-концептуальної картини світу, кваліфіковані залежно від ступеня абстрагування когнітивних процесів, які віддзеркалюючи світ національного сприйняття, забезпечують його оперативне осмислення та пізнання. Особливу роль у цьому процесі відіграють стереотипи - структури культурно-специфічних фонових знань, що існують на когнітивно-ментальному рівні, $\epsilon$ результатом узагальнення досвіду з опертям на знання про світ.

Стереотипи входять до складу нашого світогляду, наших переконань; вони є власне уявленням про світ - не таким, яким світ $\epsilon$ насправді, а лише тим як уявляє його конкретна людина, група людей чи спільнота. За допомоги стереотипів накопичена інформація уявляється не просто як сума корисних знань, але як певним чином організований та впорядкований процес сприйняття дійсності, який завдяки своїй структурованості може бути переданий наступним поколінням. Роль посередника у цьому процесі виконує мова. Саме мова забезпечує найбільш природний доступ до свідомості і розумових процесів, причому зовсім не через те, що результати розумової діяльності - вербалізуються, а тому що ми знаємо про структури свідомості тільки завдяки мові, яка дозволяє повідомити про ці структури і описати їх за допомогою будь-якої природної мови.

Стереотипи, виникнувши у соціумі, $є$ глибоко національні, «детерміновані культурою, впорядковані й фіксовані структури етнічної свідомості, що уособлюють результат пізнання дійсності етнічною спільнотою, закріплюють у свідомості людини культурні традиції, обряди, ритуали, звичаї, вірування, забобони, особливості мовленнєвої й невербальної поведінки тощо» [3, с. 147]. Відтак поняття стереотипу слід розглядати в безпосередньому зв’язку з поняттями «етнос», «нація», «народ». Звідси терміни «національний стереотип» - «етнічний стереотип» (як синоніми до останнього послуговуємося термінами «культурний стереотип», «етнокультурний стереотип»).

У сучасній науковій традиції існують різні підходи до проблеми співвідношення «етнічного» та «національного», що відобразилися на розумінні етнічного стереотипу. Зокрема, спостережені думки щодо ототожнення відповідних понять: «Етнічними (національними) стереотипами називають усталені, тривкі, колективні переконання про особисті характеристики, переважно персональні риси, а також про поведінкові типи, які нібито притаманні певній етнічній/національній групі» [4, с. 387-388]; «Стереотип національний (етнічний) - схематичний образ представника будь-якої етнічної групи, зазвичай, 
який представляє спрощені, іноді односторонні знання про психологічні особливості та поведінку людей іншої нації» [2, с. 249].

Ми обстоюємо іншу позицію і розмежовуємо ці два поняття на тій підставі, що поняття етнічного стереотипу більш широке і консолідує характеристики багатьох етносів, на основі яких і сформувалась нація. Водночас, національні стереотипи, які акумулюють історичний досвід нації, у жодному разі не можна ігнорувати. Це означало б відмову від уваги до нормальних і природніх відмінностей між етнічними спільнотами. Означену думку підтверджують і розмисли Ф. Бацевича, який наголошує: «етнічний стереотип - спрощений, схематизований, емоційно забарвлений і стійкий образ певної етнічної спільноти, який характеризує всіх представників цієї спільноти. Національний стереотип - образ, який, позначаючи етнічну, або національну групу, передбачає наявність певної риси у всіх іiі представників» $[1$, c. 260].

На нашу думку, національні стереотипи, що існують у формі стереотипів поведінки і стереотипів сприйняття (стійких перцептивних образів, що склалися у представників етносу і які проявляються у тісному взаємозв'язку своїх когнітивних і емоційно-оцінних компонентів), відображають характеристики сформованої нації, є природніми складниками національної свідомості, і допомагають людям осягнути свою національну приналежність, свою відмінність від інших національних спільнот. Разом із тим, національні стереотипи дозволяють особистості без особливих роздумів співвіднести власну оцінку будь-якого явища 3 політичною ціннісною шкалою своєї групи. Бажаючи відповідати очікуванням групи, індивід мимоволі визначає свої політичні симпатії в межах, що диктує така шкала. Тобто, можна говорити, що національні стереотипи політизовані й ідеологізовані.

Отже, поняття «етнічний стереотип» $\mathrm{i}$ «національний стереотип», що зумовлюють функціонування один одного, є за своєю сутністю різними поняттями: до структури етнічного стереотипу може входити безліч різноманітних характеристик, які створюють образ етнічної групи, національний же стереотип репрезентує найяскравішу ознаку представників однієї нації чи навіть окремого регіону; етнічний стереотип пов'язаний із культурною спадщиною етносу і являє собою поняття культурологічне, тоді як національний стереотип напряму пов'язаний із державністю й являє собою поняття соціологічне.

\section{Література:}

1. Бацевич Ф. С. Основи комунікативної лінгвістики : підручник. Київ : Академія, 2004. 344 с.

2. Крысько В. Г., Фельдштейн Д. И. (ред.) Этнопсихологический словарь. Москва : МПСИ, 1999. 343 с.

3. Селіванова О. О. Сучасна лінгвістика: термінологічна енциклопедія. Полтава : Довкілля-К, 2006. 716 с.

4. Середа В. Вплив польських та українських шкільних підручників з історії на формування польсько-українських етнічних стереотипів. Вісник Львівського університету. Серія історична. 2000. Вип. 35-36. С. 387-398. 


\section{I. М. Хом'як,}

доктор педагогічних наук, професор, академік АН ВШ Украӥни,

завідувач кафедри украӥнської мови і літератури

Національного університету «Острозька академія»,

M. Ocmpoz,

ivan.khomiak@oa.edu.ua

\section{УКРАЇНСЬКА МОВА - ГАРАНТІЯ ЗБЕРЕЖЕННЯ НАЦІОНАЛЬНОЇ ІДЕНТИЧНОСТИ}

Українська мова виконує різноманітні функції. Окрім основних: емотивної (функції вираження почуттів, волі співрозмовника), референтної (для позначення предметів зовнішнього світу), метамовної (з метою говорити про мову мовними засобами), фатичної (для встановлення контакту), конативної, або модальної, мові притаманні освітньо-виховна, управлінська, інформаційна, дослідницька, естетична та інші функції, що взаємодіють і підсилюють одна одну.

Ми задалися метою проаналізувати атрибутивні функції мови, що є запорукою національної єдности. У «Політичному словнику» за редакцією В. К. Врублевського, В. М. Мазура, А. В. М'яловицького атрибут (від лат. attribuo - надаю, наділяю) характеризується як невід'ємна властивість, істотна ознака предмета або явища. У тлумачному одинадцятитомному «Словнику української мови» вищеозначену характеристику доповнено: це ознака або предмет, які становлять характерну прикмету кого-, чого-небудь; означення [5, с.72]. Атрибути держави уособлюють ідентифікаційні національні символи, пов'язані з розвитком титульної нації та їі роллю у становленні державности, як-от: прапор, герб, гімн; власна територія із визначеними кордонами, офіційна назва країни, час заснування або дата першої письмової згадки про неї; мова як найважливіший маркер національної самовизначености та ін.

Українська мова як невід'ємний державний атрибут зберігає свою історичну спадкоємність від давньокиївської доби, є визначальним фактором національної безпеки, згуртованости нації. Державний статус української мови закріплено в десятій статті Конституції України. Проблему утвердження державної української мови порушено в публікаціях Ю. Андруховича, І. Дзюби, О. Забужко, А. Загнітка, Р. Зорівчак, С. Караванського, І. Лопушинського, Л. Масенко, В. Німчука, А. Погрібного, О. Пономарева, О. Сербенської, І. Фаріон, І. Ющука та ін.

Під національною ідентичність розуміємо властиву українській мові суспільну тотожність, що відображає характерні риси українців, шанобливе ставлення до державних атрибутів, зокрема української мови, яка об'єднує націю і є запорукою національної єдности.

Без поступального розвитку української мови й повнокровного функціювання її в системі освіти, науки, культури, державному управлінні, сфері послуг неможливо збудувати Українську державу. 25 квітня 2019 року Верховна Рада України здійснила важливий крок на шляху до ментальної незалежности - ухвалила закон «Про забезпечення функціонування української мови як державної» [7], згідно 3 яким єдиною державною мовою в Україні є українська, а спроби запровадження в країні офіційної багатомовности всупереч Конституції України кваліфіковано як кроки, що провокують мовний розкол країни, міжетнічне протистояння і спрямовані на насильницьку зміну чи повалення конституційного ладу.

Проаналізуємо, як використовується українська мова в часи незалежної України, якою мірою впроваджується в життя Закон «Про забезпечення функціонування української мови як державної».

У засобах масової інформації «розкошують» кальки з російської мови, мовлення посадових осіб знебарвлене суржиком, деякі з них з року в рік принципово ігнорують державну мову на найвищих щаблях влади, українські фільми здебільшого російськомовні. І це в час, коли Росія веде гібридну війну проти України, приводом для якої називає захист російськомовного населення. 
Народний депутат України М. Бужанський вніс до парламенту законопроєкт про скасування Закону про мову, який, на його думку, «нічого спільного із захистом і розвитком української мови не має» $\mathrm{i}$ «спрямований на дискримінацію носіїв інших мов, насамперед російської». Глава комітету Верховної Ради з питань гуманітарної та інформаційної політики О. Ткаченко заявив, що прийняття мовного Закону створило багато ризиків для суспільства $\mathrm{i}$, зокрема, для новообраних депутатів. Нардепи М. Бужанський і О. Волошин внесли до Верховної Ради України законопроєкт щодо використання народними депутатами російської та інших мов національних меншин на пленарних засіданнях Верховної Ради, парламентських слуханнях, у роботі органів парламенту.

Виникає питання, чи є підстави в народних обранців у стінах парламенту розхитувати мовний атрибут Української держави? До Дня Незалежности в серпні минулого року соціологічна група Рейтинг» провела дослідження «Динаміка патріотичних настроїв українців». На питання, чи вважають опитані себе патріотами, 83\% громадян України заявили, що так. Патріот, як стверджує тлумачний «Словник української мови», - це той, хто любить свою батьківщину, відданий своєму народові, готовий для них на жертви й подвиги [6, с. 97]. Почуття патріотизму зобов'язує українських громадян спілкуватися мовою держави, яка надихає на героїчні вчинки. За результатами загальнонаціонального дослідження Фонду «Демократичні ініціативи імені Ілька Кучеріва» разом із соціологічною службою «Українського центру економічних і політичних досліджень імені Олександра Разумкова» з 13 по 18 грудня 2019 року, проведеного в усіх регіонах України, окрім Криму та окупованих територій Донецької і Луганської областей, 70\% українців вважають, що єдиною державною мовою повинна лишатися українська.

У лютому телевізійний канал «1+1» представив план нового сезону 2020 року, у якому комедії планують знімати українською мовою, а всі сім нових серіалів мелодрам вийдуть на екран російською мовою, оскільки державна мова, на думку телевізійників, «складніша для цього жанру». «Знайти тональність української мови, щоби глядач іiї сприймав, досить непросто. За нашими спостереженнями, мелодрами українською мовою виглядають гірше, ніж комедії,, - сказала на сторінці Facebook продюсерка серіалів і фільмів «1+1» О. Сремєєва.

Особи, які здійснюють ідейно-художній та організаційно-фінансовий контроль за постановкою фільмів ще зі шкільної парти мали б знати, що українська мова - одна з найрозвиненіших і найпісенніших у світі. Відтак обмежимося новим підтвердженням сказаного: за видатну творчу діяльність, високу поетичну майстерність цьогорічним лавреатом Міжнародної літературної премії імені Франса Кафки став український поет-пісняр А. Демиденко. Телевізійникам час уже усвідомити головну місію українського кіно - творити ідентичність української нації, бути ії ідентифікатором. Відверте висловлювання телепродюсерки про меншовартість української мови викликає обурення, за таку мовну політику телеканал ризикує втратити ліцензію.

Державний статус української мови допомагає позбутися відчуття принизливого комплексу меншовартості і водночас активно стимулює усвідомлення своєї національної гідности, у формуванні якої чільну роль має відігравати інтелектуальна еліта, насамперед вище керівництво держави, яке особистим прикладом зобов'язане утверджувати престиж української мови. Прикро чути, коли можновладці вдаються до неправомірно зверхніх займенникових форм, кажучи, як вони «дбають про цю мову», «володіють цією мовою», як і «обіияють цій державі», «керують цією крайною» чи «працюють для цього народу». Очевидно, логічніше в цих контекстах уживати не вказівні займенники, що виражають дистанційованість, непричетність носія мови до українського етносу, а присвійні - нашу, нашою, мойи, своєю, для намого, які уособлюють приналежність обранців до нашого народу і нашої держави.

Таким чином, боротьба за українську мову знаменує собою боротьбу за незалежність нашої держави. Атрибутивні функції мови зумовлені тим, що вона є гарантією збереження національної ідентичности українського етносу, головним гарантом консолідації українського суспільства.

\footnotetext{
Література:

1. Словник української мови. Т.1. Київ: Наукова думка. 1970. 799 с.

2. Словник української мови. Т.6. Київ: Наукова думка. 1975. 832 с.

3. Zakon.rada.gov.ua/Iaws/show/2704-19.
} 


\section{О. М. Антончук,}

кандидат педагогічних наук,

доцент кафедри стилістики та культури украӥнської мови

Рівненського державного гуманітарного університету,

м. Рівне,

abc7500@ukr.net

\section{ФОРМИ ДІЛОВОЇ КОМУНІКАЦЇ̈ У ПРОЦЕСІ ВИВЧЕННЯ КУРСУ «УКРАЇНСЬКА МОВА ЗА ПРОФЕСІЙНИМ СПРЯМУВАННЯМ»}

Курс «Українська мова (за професійним спрямуванням)» має на меті «сформувати в майбутніх спеціалістів професійно зорієнтовані вміння і навички досконалого володіння українською літературною мовою у фаховій сфері» [3, с. 15]. Загальноприйнятими формами ділової комунікації є ділова розмова, нарада, переговори, публічне мовлення, конференція, дебати з опонентом, ділове листування, розмова по телефону, різноманітні ділові зустрічі.

Під час викладання курсу для здобувачів вищої освіти РДГУ спеціальності «014 Середня освіта (Історія)» враховуємо особливості професійної комунікації майбутніх вчителів історії, а саме: уміння ознайомити школярів з минулим людства, сприяти формуванню в учнів наукових поглядів на процеси суспільного розвитку, історію суспільства і культури, розуміння загальних закономірностей історико-культурного процесу і своєрідності історичного шляху народів.

Уміння вести соціальний та міжособистісний діалог є важливим під час проведення індивідуальних та колективних форм фахового спілкування. 3 урахуванням каналів комунікації виділяють: безпосереднє спілкування («обличчя до обличчя»); опосередковане (телефон, радіо, телебачення).

Опрацьовуючи тему «Культура усного фахового спілкування. Форми колективного обговорення професійних проблем», здобувачі вищої освіти виконують такі практичні завдання:

1. Складіть проєкт ток-шоу «Україна сьогодні: здобутки, виклики, перспективи».

2. Складіть діалог на тему «Телефонна розмова», дотримуючись правил мовленнєвого етикету, скориставиись ситуацією, коли вам телефонує науковий керівник курсової роботи.

3. Прослухайте діалог між ведучим і політиком у програмі «Велика політика» $і$ схарактеризуйте його за такими параметрами: а) місче і час спілкування; б) форма спілкування; в) мета учасників спілкування; г) ініціатива спілкування; г) засоби мовленнєвого етикету; д) типи помилок. Чи ефективними є обрані комунікативні тактики та стратегіï?

Готуючись до виступу, доповідач може написати доповідь на папері. При цьому йому слід врахувати, що розмовна мова значною мірою різниться від писемної, вона менш формалізована, вільніша, сприймається легше. Проте не можна нехтувати дотриманням загальноприйнятих літературних норм у користуванні орфоепічними, морфологічними та стилістичними засобами мови, адже важливою умовою успіху є бездоганна грамотність. Мовлення має бути не тільки правильним, а й лексично багатим, синтаксично різноманітним.

У процесі вивчення теми «Риторика і мистецтво презентації» пропонуємо такі завдання для формування ораторської вправності:

1. Навівши переконливі аргументи, спростуйте або заперечте тезу Івана Огієнка «Кожний учитель - якого б фаху він не був - мусить досконало знати свою соборну літературну мову й вимову та соборний правопис. Не вільно вчителеві виправдовувати свого незнання рідної мови не фаховістю».

2. Підготуйте промову для одногрупників із теми «Украӥнський молодіжний сленг», розкрийте історичні та психологічні особливості изього поняття.

3. Доберіть $і$ запишіть 3-4 артументи, щзб підтвердити такі думки: Мати вищу освіту - нині престижно. Поступливість - риса слабкої людини. Добра освіта належно поцінована нині. 
4. Прочитайте початок тексту і його кінець. Про що він? Визначте стиль. Додайте доказову частину тексту до поданих вступної та заключної частини.

Ознаки кризи правопорядку в Україні сьогодні очевидні. Існують різні думки з приводу того «хто винен?» у цьому і «що робити?», аби забезпечити в країні суворе дотримання закону.

Отже, простежується закономірність: яка правова культура людей - такий і правопорядок вони матимуть.

Важливо, аби в умовах суб'єкт-суб'єктного навчання викладач не на себе брав пояснення лінгвістично-дидактичних фактів, явищ, понять, а стимулював студентів самостійно міркувати, логічно мислити, доходити висновків [2].

У процесі вирішення проблемних задач, участі в дискусіях, обгрунтуванні власних позицій виникає потреба в застосуванні критичного мислення. Значення прикметника критичний «Великий тлумачний словник сучасної української мови» трактує так: 1. Стосується до критики; який містить критику; який грунтується на науковій перевірці правдивості, правильності чого-небудь. 2. Здатний виявляти та оцінювати позитивне й негативне в кому -, чому-небудь; вимогливий [1, с. 588].

В умовах інформаційного суспільства викладач втрачає функцію транслятора знань, його завдання - допомагати студентам розв'язувати проблемні завдання, розвивати вміння робити самостійні висновки на основі дібраних аргументів.

\section{Література:}

1. Великий тлумачний словник сучасної української мови / укладач і гол. ред. В. Т. Бусел. Київ : Ірпінь : Перун, 2007. $1736 \mathrm{c}$.

2. Хом'як І. М. Розвиток критичного мислення у студентів-філологів. Українська мова та література в школi. 2019. № 1. C. 2-7.

3. Шевчук С. В., Клименко І. В. Українська мова за професійним спрямуванням : підручник. Вид. 3-тє, випр. і доп. Київ : Алерта, 2013. 696 с. 


\author{
Г. В. Гайович, \\ кандидат філологічних наук, дочент, \\ професор кафедри мовної підготовки, \\ Інститут державного управління \\ у сфері ичивільного захисту, м. Київ \\ halina15ukr@gmail.com
}

\title{
КОМУНІКАТИВНІ НАВИЧКИ ТА УСПНШНА КАР'ЄРА ДЕРЖСЛУЖБОВЦЯ. ЯК ЦЕ ПОСДНУСТЬСЯ?
}

У Національній рамці кваліфікацій, яка є системним і структурованим за компетентностями описом кваліфікаційних рівнів [1], одним із таких рівнів $є$ комунікація, що трактується тут як “взаємодія осіб 3 метою передавання інформації, узгодження дій, спільної діяльності”. Визнання комунікативних умінь невід'ємним компонентом розвитку особистості, насамперед, свідчить про те, що в Україні сьогодні, як і в усьому світі, велике значення приділяється умінню людини спілкуватися. Сьогодні вже недостатньо лише професійних навичок для успішної кар'єри, важливим елементом професійно компетентної людини стають так звані “м’які навички” (“soft skills”), які є основою виживання людини в сучасному світі. Серед іншого, вони також включають комунікативні вміння, зокрема, уміння спілкуватися в письмовій формі та усній як вербально, так і невербально. Окрім того, можна говорити про особливості офлайн та онлайн спілкування тощо. Така увага до комунікативних умінь особи дає підстави для більш ретельного дослідження цієї тематики.

Якщо ж говорити про портрет професіонала тієї чи іншої галузі, то тут це уміння є незамінним. Особливої уваги заслуговують професії, для яких визначальною є схема “людина-людина”, тобто, орієнтовані на роботу з людьми і для людей. Одним з таких напрямів $є$ праця державних службовців, серед професійних обов’язків яких є й такі, як аналіз “державної політики на загальнодержавному, галузевому і регіональному рівнях", підготовка “пропозицій стосовно іiї формування, у тому числі розроблення та проведення експертизи проектів програм, концепцій, стратегій, проектів законів та інших нормативно-правових актів, проектів міжнародних договорів", “забезпечення надання доступних і якісних адміністративних послуг” та ін. (стаття 1, п. 1) [3]. Для виконання цих завдань передбачено використання державної мови, оскільки в Законі України “Про державну службу” чітко прописано: “державна мова - це українська мова, якій Конституцією України надано статус мови офіційного спілкування посадових осіб державних органів та органів місцевого самоврядування під час виконання посадових обов'язків, а також мови діловодства і документації цих органів та посадових осіб” (стаття 2, п. 1) [3]. Однак, на думку науковців, професіоналів з різних сфер та й просто небайдужих людей сьогодні питання поліпшення комунікативних умінь працівників вимагає не лише теоретичних, законодавчих норм, але й широкого практичного втілення. Цікавою з цього погляду видається думка науковців-практиків Драгомирецької Н.М., Кандагури К.С. та Букач А.В., які у своєму навчальному посібникові з комунікації для державних службовців зазначають: "В Україні варто сформувати комунікаційну політику як динамічну систему, котра включена в усі види діяльності суб’ єктів державного управління і спрямована на розвиток суспільного життя та реалізацію національних стратегій розвитку держави. Доречно виробити довгострокову Національну комунікативну стратегію, яка може мати декілька рівнів функцій: основні, допоміжні, правові, організаційно-функціональні. У межах цієї стратегії варто визначити форму правового визнання комунікаційної діяльності” [2, с. 32]. Для втілення в життя таких пропозицій, вважаємо, насамперед, необхідно забезпечити вільне володіння українською мовою представниками публічного простору, зокрема й держслужбовцями.

Проблема вивчення української мови та широкого ï застосування на всіх державних рівнях $\epsilon$ актуальною сьогодні, як ніколи. Ця проблема набула державної ваги. Підтвердженням цьому є й су- 
часне українське законодавство, й великий резонанс цього питання в суспільстві. Роль вербального спілкування в професійному дискурсі грунтується на знанні основних правил та принципів ділової риторики, теоретичних засад комунікації як науки, культури мови в діловому спілкуванні, основних норм сучасної української літературної мови тощо. Для державних службовців, на нашу думку, також важливими показниками компетентності $є$ володіння культурою дискусії, наявність сукупності ряду вербальних і невербальних умінь та навичок, які грунтуються на вмінні послуговуватися як індивідуальним, так і корпоративним іміджем. Моделі поведінки в міжособистісному спілкуванні в діловій сфері, як правило, чітко обумовлені принципами корпоративної етики й моралі. Однак ці моделі багато в чому залежать від сприйняття та адекватної інтерпретації їх комунікативними партнерами. Тож професіоналу важливо вміти відчути, передбачити можливі шляхи розвитку комунікативної ситуації та вибрати найбільш виправдану для цього модель, яка буде найбільш ефективною. Комунікативну ефективність у цьому професійному дискурсі доцільно порівнювати з досягненням короткострокових і довгострокових цілей публічного управління.

Отже, як показують згадані вище державні документи, піднята тема заслуговує на ретельне дослідження. Здатність людини, яка займає державну посаду, взаємодіяти з іншими людьми, адекватно інтерпретувати отримувану інформацію, а також правильно ії передавати, створювати, знаходити $\epsilon$ невід'ємним показником iï фахової компетентності. Залишається питанням, як досягти цієї здатності? Адже реалії нашого життя доводять, що практика поки що залишається далекою від теорії. Тож у перспективі плануємо працювати над пошуком, розробкою і впровадженням практичних методик 3 комунікації. Вважаємо, що для цієї роботи важливим є залучення представників професії, оскільки вони перебувають у цьому дискурсі, а отже, найкраще знають ті сторони, комунікації зокрема, які потребують коригувань.

\section{Література:}

1. Постанова Кабінету Міністрів України від 23 листопада 2011 р. № 1341. URL: https://zakon.rada.gov.ua/laws/ show/1341-2011-\%D0\%BF

2. Драгомирецька Н.М., Кандагура К.С., Букач А.В. Комунікативна діяльність в державному управлінні : навч. пос. Одеса : ОРІДУ НАДУ, 2017. 180 c. URL: http://www.oridu.odessa.ua/9/buk/new_26_02_18-2.pdfВiдомості Верховної Ради. 2016. № 4. с. 43. URL: https://zakon.rada.gov.ua/laws/show/889-19 


\section{T. В. Костолович,}

кандидат педагогічних наук, старший викладач

кафедри теорії і методик початкової освіти

Рівненського державного гуманітарного університету,

м. Рівне

tkostolovich@ukr.net

\section{СУЧАСНІ ФОРМИ ОРГАНІЗАЦІЇ НАВЧАННЯ У ЗАКЛАДАХ ВИЩОЇ ОСВІТИ У ПРОЦЕСІ ВИВЧЕННЯ ЛІНГВІСТИЧНИХ ДИСЦИПЛІН}

Підготовка компетентних, конкурентноспроможних майбутніх вчителів залежить від ефективного та раціонального впровадження різноманітних сучасних форм організації навчання в освітній процес 3BO.

Форма організації освітнього процесу - спосіб організації, побудови й проведення навчальних занять, у яких реалізуються зміст навчальної роботи, дидактичні завдання і методи навчання [2, С. 69].

У положенні «Про організацію навчального процесу у вищих навчальних закладах» наголошено, що освітній процес здійснюється у таких формах: навчальні заняття, виконання індивідуальних завдань, самостійна робота студентів, практична підготовка, контрольні заходи. Основні види навчальних занять - це лекція, лабораторне, практичне, семінарське, індивідуальне заняття, консультація. Інші види навчальних занять визначаються у порядку, встановленому ЗВО [3].

У педагогічній літературі постійно ведуться дискусії про проблеми впровадження та удосконалення форм організації освітнього процесу у ЗВО, про підвищення ефективності процесу навчання, про визначення терміна «форма навчання» тощо.

Організацію лекційних, семінарських, практичних, лабораторних занять досліджували К. Баханов, В. Власов, О. Пометун та ін.

I. Дроздова подає розлогу структурну організацію форм навчання у ЗВО, яка утворює сталу систему, до складу якої входять: лекції (лекції-інформації, проблемні, лекції-візуалізації, лекції-прес-конференції), семінарські заняття (просемінар, власне семінар, спецсемінар, семінар-дослідження); практичні заняття, самостійна робота (під керівництвом викладача, без керівництва викладача); інноваційні форми організації: (неімітаційні (дискусії, екскурсії), імітаційні неігрові (аналіз конкретних ситуацій, розв'язання виробничих завдань, розбір документації, дії за інструкцією); імітаційні ігрові (ділові ігри, рольові ігри, ігрове проектування) [1, с. 22]. I. Хом’як акцентує увагу на лабораторних, тьюторських заняттях, умотивовує роль практик, консультацій, гуртків, студій, дослідницьких груп, значення колоквіумів у навчальному процесі вищої школи [4, с. 11].

I. Дроздова наголошує на ефективності лекцій діалогового типу, умовами проведення яких є: 1) викладач вступає в контакт зі студентами як співрозмовник, що хоче поділитися 3 ними своїм знанням, досвідом; 2) наставник не лише визнає право студента на власні судження, а й зацікавлений у них; 3) матеріал лекцій будується за принципом обговорення шляхів вирішення навчальних проблем iз різного погляду; 4) лектор демонструє способи розв'язання об'єктивних протиріч у науці, контакт зі студентами будується таким чином, щоб підвести їх до самостійних висновків, зробити учасниками процесу підготовки, пошуку і знаходження шляхів вирішення протиріч, створених самим викладачем; 5) викладач ставить запитання і стимулює самостійний пошук відповідей на них [1, с. 24]. Вважаємо необхідним використовувати різні форми проведення занять із наданням їм діалогового характеру.

Самостійна робота на сучасному етапі реформування вищої освіти в Україні розглядається як одна 3 найважливіших форм навчання, основний засіб оволодіння програмовим матеріалом у вільний від аудиторних занять час. Проблемі організації самостійної роботи студентів різних спеціальностей присвячено праці І. Гавриш, І. Дроздової, С. Карамана, І. Климової, Г. Литвиненко, Л. Мацько, В. Мусієн- 
ко, І. Нагрибельної, Н. Остапенко, О. Симоненко, І. Хом’яка, С. Шевчук та ін. Існує багато визначень самостійної роботи, але нам імпонує формулювання I. Хом'яка, який розуміє її як «особливу форму організації навчальної діяльності студентів, спрямовану на пошук необхідної інформації, осмисленого і творчого сприймання іiї з метою вироблення професійної компетентності » [4, с. 12]. Учений визначає такі види самостійної роботи, як: підготовка доповідей, рефератів; робота $з$ підручником, словником, навчальним посібником; розв'язування педагогічних задач; виконання лабораторних робіт; організація експериментальної роботи; участь у роботі наукових гуртків, студій, проблемних груп; курсові, бакалаврські, магістерські роботи і т. ін. [Там само]. Вважаємо, що використання лінгвопедагогічних задач, пропонованих I. Хом'яком, буде позитивно впливати на формування комунікативної компетентності, «оскільки вони залучають студентів до аналітичних спостережень, самостійного аналізу ймовірних професійних ситуацій, до занурення у виучуваний матеріал, встановлення лінгвістичних, логічних i психологічних зв'язків і відношень між аналізованими фактами та явищами» [4, c. 15].

При викладанні дисциплін лінгвістичного циклу ми використовуємо різноманітні форми навчання (i традиційні, і нетрадиційні). Нетрадиційні форми активізують навчання студентів, сприяють виробленню культури мовлення, розвивають індивідуальні здібності, навички комунікації, ерудицію тощо.

Для підвищення ефективності процесу навчання лінгвістичних дисциплін у сучасних 3ВО необхідно удосконалювати увесь комплекс форм навчання (лекційні, семінарські, практичні, самостійну роботу), а також і позааудиторні форми навчання.

\section{Література:}

1. Дроздова I. Методика аудиторних і позааудиторних занять як основа розвитку професійного мовлення студентів-нефілологів. Укр. мова і літ. в шк. 2013. № 1. С. 21-24.

2. Мелешко Г. М. Вступ до педагогічно професії : навч. посіб. К. : Академвидав, 2010. 200 с. С. 68-75.

3. Про затвердження «Положення про організацію навчального процесу у вищих навчальних закладах» zakon. rada.gov.ua

4. Хом’як I. Самостійна робота як компонент цілісного педагогічного процесу. Укр. мова і літ. в шк. Украӥни. 2016. № 7-8. С. 11-17. 


\section{Н. I. Скрипник,}

кандидат філологічних наук, завідувач кафедри української філології

Комунального закладу вищзої освіти

«Вінницький гуманітарно-педагогічний коледж»,

м. Вінниия,

nadiyvnua@gmail.com

\section{ДИСКУРС ЯК КЛЮЧОВА ОДИНИЦЯ МОВЛЕННСВОЇ ДІЯЛЬНОСТІ}

Дискурс - найзагальніша категорія організації засобів мовної системи у спілкуванні, поле зустрічі особистостей у конкретних психологічних і соціальних обставинах. Дискурс являє собою реалізацію мовної компетенції в процесі комунікативно-мовленнєвої діяльності.

Про зацікавленість науковців проблемами дискурсу свідчить велика кількість праць вітчизняних та зарубіжних дослідників, зокрема Н. Арутюнової, Ф. Бацевича, О. Бессонової, А. Бєлової, В. Дем’янкова, В. Карасика, С. Кубрякової, М. Макарова, М. Полюжина, П. Серіо, А. Токарської, Дж. Філіпса, Дж. Фіске, Р. Ходжа, І. Шевченко, Дж. Юла.

Учені (Ф. Бацевич, В. Варакіна, О. Кубрякова, К. Кусько, А. Нікітіна, Т. Ніколаєва, Н. Миронова, О. Морозова, Ю. Степанов та ін.) зауважують, що термін «дискурс» є складним і багатовимірним поняттям сучасної гуманітарної науки.

Для дослідників предметом дискусії залишається розмежування понять «дискурс», «текст» і «мовлення», які є надзвичайно важливими для розуміння терміну «дискурс».

Дефініція «дискурс» походить від французького слова «discours» і означає «мовлення» або «розмова». Термін «дискурс» має цілий спектр значень, що варіюють від сумісних до взаємовиключних. Недаром найбільш цитоване мовознавцями визначення дискурсу як «мовлення, зануреного у життя» [1, с. 137]. А формами, які репрезентують дискурс, є: інтерв'ю, репортажі, наукові теорії, соціальні події, конференції, бесіди тощо. Таким чином, це не просто мовне/мовленнєве формоутворення, а й результат і чинник комунікації, живе середовище спілкування, яке, як відомо, створює нові фізичні дії, ментальні й психічні продукти.

О. Л. Бессонова зауважує: «безперечним є той факт, що дискурс затверджує своє місце в системі категорій комунікації перш за все через поняття «текст», а також через поняття «мовлення», а саме створенням певного комунікативно-мовленнєвого простору, де і відбувається комунікативна подія, що породжує текст» [4, с. 22-27].

За Ф. Бацевич, «дискурс - тип комунікативної діяльності, інтерактивне явище, мовленнєвий потік, що має різні форми вияву (усну, писемну, паралінгвальну), відбувається у межах конкретного каналу спілкування, регулюється стратегіями і тактиками учасників; синтез когнітивних, мовних і позамовних (соціальних, психічних, психологічних тощо) чинників, які визначаються конкретним колом «форм життя», залежних від тематики спілкування, має своїм результатом формування різноманітних мовленнєвих жанрів [2, с. 138]. Тобто з одного боку, дискурс - текст, занурений у життя, з особливою граматикою, лексикою, правилами слововживання і синтаксису, а з іншого - це живе спілкування, комунікація, когнітивно-мовленнєве й інтерактивне явище з усіма відповідними складовими спілкування [4, c. 12-13].

I. Шевченко та О. Морозова під мовленням розуміють мовленнєву діяльність, а під дискурсом мовлення у контексті соціальної та мисленнєвої діяльності і визначають дискурс як інтегральний феномен, як мисленнєво-комунікативну діяльність, яка протікає в широкому соціокультурному контексті, $€$ сукупністю процесу та результату, характеризується континуальністю та діалогічністю [5, с. 26-28].

Нині дискурс розглядають не лише як різновид функціонального стилю, а й як різновид мовлення (усний, писемний, науковий, художньо-белетристичний, діловий, літературний); його реалізацію в 
різних сферах спілкування (юридичний, судовий, газетний, радіодискурс, кінодискурс, театральний, рекламний, святковий); як жанр художньої літератури (прозовий, ліричний, драматичний).

Поняття дискурсу часто асоціюється з типами та формами мовлення, принципами побудови повідомлення, висловлюваннями суб'єктів, котрі говорять або пишуть, його риторикою (монологічний, діалогічний, наративний, риторичний, іронічний тощо), характеристиками мовлення окремої людини і груп людей (особистісний, неповторний, колективістський, авторитарний), а також із усіма виявами комунікації в суспільстві (комунікативний дискурс, мовний, вербальний, невербальний, сучасні дискурсивні практики, дискурс мовчання), комунікацією у межах окремих каналів (візуальний, слуховий, тактильний), виявом правил спілкування, способів викладу та втілення прагматичної мети мовців (етикетний, лайливий, дидактичний).

У цілому дискурс можна кваліфікувати як мінімальну комунікативну одиницю, ключову одиницю мовленнєвої діяльності, що виражає міжособистісну мовленнєву взаємодію й має об'єднувальну комунікативну функцію та єдину тему [6, с. 17-18].

У результаті можна констатувати, що найбільшим елементом у структурі дискурсу виступає закінчене мовленнєве спілкування (мовленнєва подія), розмова, яка співвідноситься у мовленні з макродіалогом або текстом (мікротекстом). Усні й письмові дискурси функціонують за допомогою мовленнєвих подій: переговори, бесіда, телефонна розмова, тексти тощо.

\section{Література:}

1. Арутюнова Н. Д. Дискурс. Лингвистический энииклопедический словарь. Москва: Сов. энциклоп., 1990. C. $136-137$.

2. Бацевич Ф. С. Основи комунікативної лінгвістики: навчальний посібник Київ: Академія, 2004. 344 с.

3. Бацевич Ф. С. Нариси з лінгвістичної прагматики: монографія. Львів: ПАІС, 2010. 336 с.

4. Бєссонова О. Л. Оцінний тезаурус англійської мови: когнітивний і гендерний аспекти: Дис. ... д-ра філол. наук: 10.02.04. Донецьк, 2003. $463 \mathrm{c}$.

5. Дискурс як когнітивно-комунікативний феномен / І. С. Шевченко та ін. Харків: Константа, 2005. 356 с.

6. Зернецкий П. В. Речевое общение на английском языке (Коммуникативно-функциональный анализ дискурса). Киев: Лыбидь, 1992. 144 с. 


\section{3. В. Столяр,}

кандидат педагогічних наук, старший викладач

кафедри української мови і літератури

Національного університету «Острозька академія»,

M. Ocmpoz

zoya.stoliar@oa.edu.ua

\section{ПСИХОЛОГО-ПЕДАГОГІЧНІ ЗАСАДИ ПОЧАТКОВОГО НАВЧАННЯ УКРАЇНСЬКОЇ МОВИ В УМОВАХ НУШ}

Закон України «Про освіту» визначає, що «освіта є основою інтелектуального, духовного, фізичного і культурного розвитку особистості, іiі успішної соціалізації, економічного добробуту, запорукою розвитку суспільства, об'єднаного спільними цінностями і культурою, та держави» [1], а мета освіти - сприяти формуванню людини як особистості й найвищої цінності суспільства. Відповідно заклади освіти забезпечують різнобічний розвиток інтелектуальних, творчих, фізичних здібностей здобувачів освіти, створюють належні умови для їхньої успішної самореалізації і формування компетентностей.

Компетентнісну освіту дослідники розглядають як особистісно-діяльнісну, результативну. Саме тому особистісна парадигма сучасної освіти передбачає організацію освітнього процесу, суб'єктом якого є учень із його індивідуальними потребами, зацікавленнями й творчими пошуками, самобутністю, унікальністю.

Особливо актуальним утілення особливостей компетентнісного навчання $є$ на етапі початкової освіти, оскільки саме він є першою ланкою в системі шкільної освіти, спрямованою на формування компетентностей учнів. Саме в початкових класах закладають основи розуміння того, що українська мова - це не лише навчальний предмет, не лише засіб вивчення інших предметів (оскільки в Законі України «Про повну загальну середню освіту» зафіксовано, що «кожному учневі гарантовано право на здобуття повної загальної середньої освіти державною мовою в державних, комунальних і корпоративних закладах освіти, що забезпечують шляхом організації викладання всіх навчальних предметів (інтегрованих курсів) державною мовою» [2]), а що українська мова $€$ засобом пізнання світу, реалізації себе в цьому світі, розуміння й вияву себе як представника українського етносу; вона - найважливіший символ державності України й атрибут національної ідентичності.

Питання компетентнісного підходу в процесі вивчення української мови в школі є актуальним питанням сьогодення, яке висвітлюють у своїх дослідженнях Л.О. Варзацька, М.С. Вашуленко, Т.М. Котик, О.А. Кучерук, Н.М. Остапенко, Г.Т. Шелехова та ін.

Нова українська школа, концепцією якої є навчання через діяльність, стала ресурсом для активного впровадження результатів лінгводидактичних розвідок. Ефективність діяльності НУШ забезпечує також наявність веб-ресурсу (https://nus.org.ua/), що вміщує нормативні акти, які регламентують освітній процес; наукові статті, що висвітлюють актуальні питання початкової освіти (зокрема мовно-літературної); допоміжні методичні матеріали для педагогів, учнів, батьків; корисні відеоматеріали тощо.

На основі визначених пріоритетів НУШ у початковій школі освітній процес організовують за циклами, які враховують вікові особливості учнів, рівень фізичного, інтелектуального, психічного розвитку, мотивацію школярів. Першим циклом $є$ адаптаційно-ігровий (1-2 роки навчання), другим - основний (3-4 роки навчання).

Особистісне орієнтування передбачає врахування вікових особливостей учнів, психічної готовності до певного виду діяльності під час вивчення української мови. А тому програму для початкової школи побудовано з урахуванням таких принципів навчання: дитиноцентрованості і природовідповідності; узгодження цілей, змісту і очікуваних результатів навчання; науковості, доступності і практичної спрямованості змісту; наступності і перспективності навчання; взаємозв'язаного формування ключових і 
предметних компетентностей; логічної послідовності і достатності засвоєння учнями предметних компетентностей; можливостей реалізації змісту освіти через предмети або інтегровані курси тощо [5].

Зміст програм для учнів початкової школи передбачає формування у здобувачів освіти ключових компетентностей, а також читацької й комунікативної (вільне володіння державною мовою, що полягає в умінні усно й письмово висловлювати свої думки, почуття, чітко та аргументовано пояснювати факти, створювати монологічні й діалогічні висловлювання; любові до читання, відчуття краси слова, усвідомлення ролі мови для ефективного спілкування та культурного самовираження; готовності вживати українську мову як рідну/державну в різних життєвих ситуаціях і дотримуватися ії норм).

Відповідно в початковому курсі мовно-літературної освіти виділено змістові лінії, що сприяють ефективному формуванню зазначених компетентностей - «Взаємодіємо усно», «Читаємо», «Взаємодіємо письмово», «Досліджуємо медіа», «Досліджуємо мовні явища». Наявність вказаних змістових ліній забезпечує досягнення мети початкового курсу мовно-літературної освіти - розвитку особистості дитини засобами різних видів мовленнєвої діяльності, формування ключових, комунікативної та читацької компетентностей; розвиток здатності спілкуватися українською мовою для духовного, культурного й національного самовияву.

Змістові лінії в початковій школі реалізують через інтегровані курси і навчальні предмети (1 клас - інтегрований курс «Навчання грамоти», 2 клас -навчальні предмети «Українська мова», «Читання» або інтегрований курс цих навчальних предметів, 3 і 4 класи - «Українська мова» і «Літературне читання»). Варто наголосити, що вчитель має можливість самостійно обирати й формувати інтегрований та автономний спосіб подання змісту предметів, добирати дидактичний інструментарій на основі власних спостережень і висновків про індивідуальні пізнавальні запити й можливості учнів (рівень навченості, актуальні стани потреб, мотивів, цілей, сенсорного та емоційно-вольового розвитку) [5].

Наявність інтегрованих курсів схвально оцінюють фахівці галузі, оскільки така форма роботи сприяє формуванню загальнонавчальних умінь, виявленню індивідуальних особливостей, здібностей, зацікавлень учнів, їхніх пізнавальних інтересів і пріоритетів у навчанні. Крім того, інтегроване навчання дає змогу учителям початкових класів застосовувати різноманітні інтерактивні методи, здійснювати 3 учнями навчально-дослідницькі проєкти [4], забезпечувати безперервність вивчення мови на текстовій основі.

Цілеспрямована робота над формуванням усіх видів мовленнєвої діяльності учнів початкової школи (слухання, говоріння, читання і письма) передбачає вивчення специфіки мовних одиниць усіх рівнів і вправне використання їх у комунікативній діяльності учнів. Ефективність ії може забезпечити врахування психологічних і педагогічних основ початкової мовно-літературної освіти, налагодження суб'єкт-суб' єктних відносин між педагогом і здобувачами освіти, створення позитивної атмосфери, за якої учні розвиваються і формуються як мовні особистості в комфортних умовах, пізнають світ крізь призму мови і художнього тексту.

\section{Література:}

1. Закон України «Про освіту». URL : zakon.rada.gov.ua/laws/show/2145-19

2. Закон України «Про повну загальну середню освіту». URL : https://zakon.rada.gov.ua/laws/show/463-20

3. Методика навчання української мови в початковій школі/ за ред. М.С. Вашуленка. Київ: Літера ЛТД, 2010. $362 \mathrm{c}$.

4. Нова українська школа: основи Стандарту освіти. Львів, 2016. 64 с. URL : http://www.osvitportal.lviv.ua/ upload/users_files/1/upload/1/nova\%20schkola\%20(pantone\%208703\%20C)-ilovepdf-compressed.pdf

5. Типові освітні програми для 1-4 класів. URL : mon.gov.ua/storage/app/media/zagalna\%20serednya/programy1-4-klas/2019/11/1-2-dodatki.pdf 


\section{Н. В. Шульжук,}

кандидат філологічних наук, доцент,

завідувач кафедри стилістики і культури украӥнської мови

Рівненського державного гуманітарного університету,

м. Рівне,

n_shulzhuk@i.ua

\section{МОВЧАННЯ ЯК НУЛЬОВИЙ МОВЛЕННЕВИЙ АКТ У СТРУКТУРІ ДІАЛОГІЧНОГО ДИСКУРСУ}

Найпоширенішою формою вияву українського літературного мовлення $є$ діалог, у якому, застосовуючи відповідні комунікативні стратегії і тактики, комуніканти реалізують свої наміри. Інтерес мовознавців до діалогу ніколи не згасав, а дослідження його мовної своєрідності з послідовним утвердженням ідей антропоцентризму та у контексті когнітивно-дискурсної лінгвістичної парадигми, зорієнтованої на «дискурсивні чинники вибору тієї чи іншої мовної форми маніфестації знань у тексті чи комунікації» [6, с. 18], актуалізувалися і в сучасних мовознавчих розвідках.

Теорія діалогу багатоаспектна: учені неодноразово здійснювали спробу визначити поняття «діалог» (Л. Якубинський, Г. Чумаков, М. Борисова, Г. Валімова, М. Мілих, Н. Буреніна, А. Скшидло, О. Ваяхіна, С. Срмоленко та ін.); проблеми діалогу розробляли на матеріалі різних мов (Н. Арутюнова, I. Святогор, В. Любопитнов, В. Дєвкін, В. Сжов, Л. Чахоян, В. Гак, М. Гаврильєв, Г. Верба, К. Свобода та ін.); особливості синтаксичної організації діалогічної репліки були предметом вивчення П. Дудика, О. Шаройко, Т. Винокур, Г. Інфантової, Н. Шведової, Г. Чумакова та ін.; комунікативні параметри діалогу досліджували Г. Сергєєва, Н. Теплицька, М. Шафіро. У вивченні діалогу чималий досвід має й українське мовознавство (А. Грищенко В. Рінберг, Д. Баранник, І. Борисюк, П. Дудик, Г. Олійник, Л. Олексієнко, Л. Безугла, І. Шевченко та ін.).

Особливості синтаксичної організації такого когнітивно-комунікативного феномена, як діалог, на матеріалі художніх текстів неодноразово були предметом лінгвістичного опису і в наших дослідженнях $[9 ; 10 ; 11 ; 12]$.

Стрімкий розвиток лінгвістичної прагматики, спрямованої на вивчення функцій одиниць мови у реальних комунікативних процесах, не лише визначив нові вектори досліджень діалогічного мовлення, для позначення якого було введено поняття «діалогічний дискурс» («мисленнєво-комунікативна мовленнєва діяльність комунікантів у широкому (ситуативно-комунікативному, соціокультурному, когнітивно-психологічному) контексті, зафіксована діалогічним текстом» $[1$, с. 9]), а й активізував інтерес дослідників до вивчення стратегій мовленнєвого впливу, що реалізуються як у прямих, так i опосередкованих способах вираження думки. Репрезентантом останніх є таке комунікативне явище, як мовчання.

Мета повідомлення - здійснити загальну характеристику семантики мовчання як стратегії адресата в актах діалогічної комунікації.

Положення про те, що у певному контексті акт мовчання може бути комунікативно значущим, не викликає сумнівів у лінгвістів [3; 4; 5; 7], оскільки така комунікативна одиниця може містити інформацію про психологічний та емоційний стан мовців, їх соціальний статус, про небажання відповідати, незнання відповіді та ін. Як семантична редукція мовчання представлене у працях О. С. Кібрика, О. П. Сковороднікова, Є. О. Федорченко, О. І. Шейгал та ін.

С. Крестинський виокремив такі функції мовчання: контрактивну, дисконтактивну, експресивну, інформативну, оцінну, рогативну, когнітивну, хезитативну, експективну, фонову, афективну, стратегічну, риторичну, синтаксичну, соціально рольову, ритуальну, соціальної позиції та маркування ролей [4]. Зауважимо, що ці функції мовчання відображають найчастотніші ситуації у мовленнєвій практиці 
комунікантів і об'єднані загальним принципом - мовчання є або власне комунікативним актом (хоча й нульовим), або його складником. Проте у будь-якому вияві воно є комунікативно значущим. Наведемо приклад реалізації стратегічної функції мовчання у діалозі двох подруг з «Нової старої баби» Л. Денисенко, які втілюють різні типи темпераменту й життєвої позиції, - колоритної правдолюбки Зойки, яку не цікавить думка інших, та вдови репресованого Варки, яка послуговується мовчанням, навмисно не бажаючи здійснювати будь-який мовленнєвий акт:

«А потім побачила, як вона у чайнику розчиняє дві пігулки аспірину.

- Ти нашьо те робиш?

- Уроди, что за ияветы в переходе втридорога сдирают, сказали, иоб розы не вяли, нужно добавлять в воду аспірин. Я, конечно, не роза, но увядать тоже не спешу. Смотри, как помолодела, видиш?

Я замовчала, бо Зойці не пояснити, щуо молодий крокодил від старого крокодила відрізняється лише розмірами. Тільки маразмів більщає» (с. 20).

Свою невпевненість та неготовність щось доводити надто спритним і прагматичним людям Варка, передбачаючи можливі заперечення, демонструє і в такій діалогічний єдності:

«- Площуадь нормальная, покатит на пару лет, но вообще запущенная. Это у вас что, кабинет? Кому оно сейчас надо? - резонно запитувала Віка Петрова про кімнату, котра нами використовувалася як бібліотека та комора.

Я знизала плечима - не вміла спілкуватися з такими спритними людьми, не могла я пояснити цій жінці, щуо у кімнаті живуть книжки, улюблені казки Славіка, мої співрозмовники, чоловіки, щзо, на відміну від інших, залишилися зі мною на старих книжкових сторінках» (с. 24).

Крім названих комунікативних функцій мовчання, очевидно, слід виокремити й етносоціокультурну, зумовлену певними нормами, культурними, етнічними та релігійними традиціями певного етносоціуму.

Отже, процеси утворення думки, під впливом яких формується двобічна мовна комунікація з безпосереднім контактом, призводять до «нерівномірної чіткості повідомлюваного змісту і до його нерівномірно повного вираження» [2, с. 6], у зв’язку з чим у матеріальній структурі діалогічної фрази не всі елементи є необхідними для вираження певного змісту. Імпліцитний зміст висловлювання презентує i семантика мовчання, яка нерідко стає ефективною стратегією в актах діалогічної комунікації, зумовленою інтенціями адресата.

Інтерпретація актів мовчання в діалогічному дискурсі лише окреслена і потребує більш докладного вивчення. Перспективним у контексті визначеної проблеми може виявитись прагматичний ефект недоговореності у чоловічій та жіночій вербальній поведінці.

\section{Література:}

1. Безугла Л. Р. Діалог, діалогічний текст та діалогічний дискурс. Вісник Харківського національного університету ім. В. Н. Каразіна. 2009. № 867. Романо-германська філологія. Методика викладання іноземних мов. Вип. 60. С. 7-14.

2. Загнітко А. П. Прагматичний аспект речення і прагматичний рівень висловлення. Актуальні проблеми сучасної філологї: Мовознавчі студії : зб. наук. пр. Рівненського держ. гуманіт. ун-ту. Рівне, 2005. Вип. 13. С. 3-7.

3. Каирбекова Р. К. Прагматический ефект недоговаривания. Прагматика и стилістика текста. Алма-Ата : Мысль, 1988. С. 83-86.

4. Крестинский С. В. Молчание как средство коммуникации и его функции в языковом дискурсе. Вестник ТвГУ. Серия «Филология». 2011. Вып. 1. С. 34-37.

5. Меликян С. В. Речевой акт молчания в структуре общения : автореф. дисс. ... канд. филол. наук : спец. 10.02.19 «Общее языкознание». Воронеж, 2000. 18 с.

6. Селіванова О. О. Сучасна лінгвістика: напрями і проблеми: підруч. Полтава : Довкілля-К, 2008.710 с.

7. Сеничкина Е. П. Семантика умолчания и средства ее выражения в русском языке : автореф. дис. ... д-ра филол. наук : спец. 10.02.01 «Русский язык». М., 2003. 33 с.

8. Скакун I. О. Перспективи антропоцентризму в сучасній науковій картині світу. Актуальні проблеми філософії та соціологї: науково-практичний журнал. Одеса : Гельветика, 2015. № 5. С. 193-196.

9. Шульжук Н. В. Особливості функціонування неповних речень у структурі діалогічної єдності. Наукові записки. Серія «Філологічна». Острог : Вид-во Нац. ун-ту «Острозька академія», 2011. Вип. 22. С. 114-117. 
10. Шульжук Н. В. Парцеляція у структурі діалогічного дискурсу: комунікативно-прагматичний аспект. Науковий вісник Міжнародного гуманітарного університету. Серія: Філологія : зб. наук. пр. Одеса, 2018. Вип. 32, т. 3. C. 140-143.

11. Шульжук Н. В. Проблеми опису діалогічного мовлення у контексті когнітивно-дискурсної лінгвістичної парадигми. Наукові праці Кам'янець-Подільського наџіонального університету імені Івана Огієнка: Філологічні науки: зб. наук. пр. - Кам’янець-Подільський : Аксіома, 2018. Вип. 46. С. 181-186.

12. Шульжук Н. В. Складноприєднувальні конструкції в діалогічному дискурсі: комунікативно-прагматичний аспект. Наукові записки Національного університету «Острозька академія» : Серія «Філологія» : наук. журнал. Острог : Вид-во Нац. ун-ту «Острозька академія», 2019. Вип. 5 (73). С. 177-180. 


\section{Х. М. Карповець,}

викладачка кафедри украӥнської мови і літератури

Наиіонального університету «Острозька академія»,

M. Oстрог,

khrystyna.karpovets.oa.edu.ua

\section{СУЧАСНІ ПІДХОДИ ДО ФОРМУВАННЯ ПРАВОПИСНОӤ КОМПЕТЕНТНОСТІ МАЙБУТНІХ ФІЛОЛОГІВ}

Нова редакція українського правопису актуалізувала питання правописної грамотності мовців, яке досі залишається проблемним із огляду на об'єктивні соціально-історичні та суб'єктивні особисті чинники. 3 іншого боку, нинішні вимоги до якості освіти, пріоритетне формування базових і предметних компетентностей, задеклароване в чинному законодавстві й описане в сучасних дослідженнях із лінгводидактики (у працях Н. Бондаренко, А. Віцюк, Н. Голуб, О. Горошкіної, В. Зінченко, В. Колєнцової, Л. Рубан, С. Омельчука, О. Роїк, І. Хом'яка та інших), доводять потребу оновлення підходів та методичного інструментарію для навчання правопису.

За визначенням Г. Дідук-Ступ'як, підхід до навчання мови - це «стратегічна концентрична система, що містить закономірності, принципи, форми, методи і прийоми роботи з мовно-мовленнєвим матеріалом» [2, с. 81]. Уже згадані орієнтири української освіти зумовлюють домінування компетентнісного підходу, спрямованого на формування в майбутніх філологів базових і спеціальних компетентностей як готовностей виконувати професійні обов'язки на основі знань і досвіду та з урахуванням ціннісних орієнтирів особистості.

Особистісно орієнтований підхід «зобов'язує» педагога усвідомлювати складний світ психічних і соціальних якостей вихованців, адже передбачає розуміння індивідуума як системи, яка визначає психічні особливості особистості [5, с. 115]. Відповідно означений підхід забезпечує оптимальні умови для мовнокомунікативного розвитку кожного студента, його самовизначення й самостановлення, сприяє культурній самоідентифікації.

Комунікативно-діяльнісний підхід має виразну практичну спрямованість, оскільки передбачає засвоєння мови з огляду на ії комунікативну значущість. Основним засобом і вирішальною умовою становлення особистості є діяльність, що спонукає особистість до самоорганізації, самореалізації та самоконтролю. У контексті формування правописної компетентності комунікативно-діяльнісний підхід зорієнтований на вдосконалення мовленнєвої діяльності студентів, вироблення комунікативних стратегій та внутрішньої мотивації.

Формувати правописну компетентність можна тільки на основі тексту, що є основним засобом $\mathrm{i}$ результатом навчання в текстоцентричному підході. Цей підхід поліфункційний, оскільки забезпечує одночасне виконання кількох завдань: 1) засвоєння мовних знань і формування мовленнєвих умінь $\mathrm{i}$ навичок на основі текстів; 2) усвідомлення структури тексту й функцій мовних одиниць у ньому; 3 ) формування вмінь і навичок сприймати, аналізувати, відтворювати, створювати, редагувати власні висловлювання; 4) вироблення й удосконалення комунікативної компетентності [4, с. 178].

Дослідницький підхід передбачає навчання студентів елементам дослідницької діяльності на основі творчого пошуку для вирішення проблемних професійно орієнтованих завдань чи життєвих ситуацій. У навчально-дослідницькій діяльності вирішальне значення має актуалізація фахових знань, їх відтворення й перенесення в нові не вирішувані досі ситуації.

Відповідного до одного зі специфічних принципів навчання правопису важливо враховувати зв'язок цього структурного рівня з іншими розділами мови. Як бачимо, структура української мови зумовлює використання системного підходу. В. Зінченко зазначає, що такий підхід до вивчення української мови передбачає усвідомлення мовних одиниць, їх функції; урахування відношень і взаємозв'язків 
кожного із сегментів мовної системи, розвиток і функціювання мови; вивчення правил і закономірностей; оволодіння системно-структурними утвореннями фонологічного, семантичного, морфологічного, синтаксичного рівнів, необхідних для розуміння й побудови мовлення. Усі перераховані умови забезпечують розвиток і саморозвиток особистості як суб'єкта мовно-мовленнєвої та пізнавальної діяльності, формування готовності до подальшого професійно зорієнтованого навчання [3, с. 14].

Правописна компетентність містить ціннісно-мотиваційний складник, тому ії формування неможливе без аксіологійного підходу, у рамках якого цінності визначають регуляторами людської поведінки, навчальної і професійної діяльності, прийняття рішень у ситуаціях вибору. Цей підхід дає змогу аналізувати процес формування системи знань, умінь і навичок через детермінованість ціннісного ставлення суб' єктів навчально-виховного процесу до змісту й результатів власної діяльності, професійних ролей і позицій [1, с. 13].

Реалізація апробовуваної методики передбачає виявлення рівнів сформованості правописної компетентності в майбутніх філологів та впровадження новітніх методів навчання, отже, використання технологійного підходу, Технології педагогічної діяльності враховують об'єктивні дидактичні закономірності, тому в конкретних умовах гарантують відповідність результату діяльності попередньо поставленим цілям [1, с. 13]. Така теза підтверджує потребу використання в процесі формування правописної компетентності майбутніх філологів технологійного підходу, що дасть змогу врахувати вихідні діагностичні дані, оптимізувати й удосконалити навчальну діяльність, підвищити ії інструментальність, інтенсивність і результативність.

Отже, упровадження в освітній процес вищої школи таких підходів до навчання, як компетентнісний, особистісно орієнтований, комунікативно-діяльнісний, текстоцентричний, дослідницький, системний, аксіологійний, технологійний, сприятиме гуманізації та гуманітаризації освітнього процесу, посиленню мотивації до навчання й самонавчання, розвитку особистісних характеристик усіх студентів академічної групи загалом та кожного окремо, підвищенню рівня грамотності писемного мовлення майбутніх філологів.

\section{Література:}

1. Вернигора О. Л. Методологічні засади використання інформаційно-комунікаційних технологій учителем-філологом в умовах сучасної загальноосвітньої школи. Сучасні інформаиійні технології та інноваційні методики навчання у підготовиі фахівиів: методологія, теорія, досвід, проблеми: зб. наук. пр. Київ-Вінниця: ТОВ фірма «Планер», 2015. Вип. 42. С.11-15.

2. Дідук-Ступ'як Г. І. Філософсько-методологічні орієнтири лінгвометодичної технології «Інтеракція різнотипових підходів» до вивчення української мови. Теоретико-практичні аспекти сучасних лінгвістичних та лінгводидактичних парадигм: матеріали Всеукраїнської науково-практичної конферениії: зб. наук. пр. Острог: Вид-во НУ «Острозька академія», 2012. С. 80-86.

3. Зінченко В. М. Методика формування мовно-мовленнєвих компетентностей на засадах системного підходу учнів старших класів гімназії: автореферат дис. ... канд. пед. наук: 13.00.02. К., 2015. 20 с.

4. Златів Л. М. Дискурсивно-текстоцентричний підхід до навчання української мови за професійним спрямуванням студентів-математиків. Наукові записки Національного університету «Острозька академія». Серія «Філологічна». 2015. Вип. 57. С. 177-184.

5. Кулик О. Особистісно орієнтований підхід до навчання як чинник мовленнєвого розвитку учнів. Педагогічний процес: теорія і практика. 2017. Вип. 2. С. 114-119. 


\author{
М. Саневська, \\ магістр, викладач кафедри україністики \\ Варшавського університету, \\ м. Варшава, \\ m.saniewska@uw.edu.pl
}

\title{
СУЧАСНА ЛЕКСИКА ПОВСЯКДЕННОГО ЖИТТЯ У НАВЧАННІ УКРАЇНСЬКОЇ МОВИ ЯК ІНОЗЕМНОЇ
}

Методика навчання української мови як іноземної розвивається дедалі швидше. Вчителі і викладачі можуть вибирати з-посеред багатьох підручників, виданих як в Україні, так і за кордоном. Як приклад можна навести львівську серію «Яблуко», львівський «Крок 1» і «Крок 2», «Мандрівку Україною» чи «Мій Львів». Підручники для вивчення української мови, спрямовані до окремих груп (напр. польських студентів - філологів), чи присвячені окремій тематиці, укладають викладачі з Польщі (Варшава, Познань).

Методика викладання української мови як іноземної залишається також у сфері зацікавлення дослідників. Науковці видають статті та книжки, присвячені цій проблематиці, як напр., «Теорія і практика викладання української мови як іноземної» чи монографія О. Туркевич «Становлення терміносистеми методики викладання УМІ».

Головна мета нашої доповіді - звернути увагу лише на важливу проблему, яка може з'явитися в процесі викладання української як іноземної, тобто - питання засвоєння студентами сучасної повсякденної лексики. Ми не будемо детально аналізувати всього, що містить згадана проблематика, зосередимося на декількох прикладах, які засвідчують те, з чим доводиться змагатися як учителям, так студентам.

Спочатку визначимо, як варто розуміти сучасну лексику повсякденного життя. До неї відносимо всі слова, що називають предмети, якими ми користуємося щодня, а також ті, які з'явилися одночасно 3 появою предметів чи явищ. Трапляється, що це відносно нові лексеми, які називають, наприклад, нові елементи обладнання, одягу тощо.

Чому саме така лексика стала об’єктом цієї розвідки?

Наснагою для дослідження були розмови зі студентами вищих курсів української філології, які вказали, що дуже часто працюють зі складними науковими текстами, іноді перекладають рішення суду тощо, а бракує їм вміння спілкуватися в ситуаціях щоденного життя, наприклад, ремонт квартири, догляд за волоссям чи керування машиною. Їхні слова заохотили до дальших пошуків - було ретельно перевірено книги, з якими ми працювали, і виявилося, попри те, що існує багато матеріалів, підручників і словників, сучасна практична лексика часто залишається поза увагою укладачів. Вона 3'являється на початку навчання (рівень А1 - Б1) і в дуже обмеженому обсязі. Звичайно, початківцям не потрібні детальні описи, а учнів не варто перевантажувати надто складною лексикою. Сучасна методика спрямована на те, щоб учні почали швидко спілкуватися, навіть на базовому рівні, для цього достатньо небагато слів. Крім того, у підручниках на початкових рівнях уміщують слова 3 найбільшою частотністю вживання, а не всі сучасні назви мовці використовують у повсякденній практиці. Пізніше як викладачі, так і студенти хочуть перейти до складніших, а водночас цікавіших і дискусійних тем. Це призводить до ситуації, що студенти зрозуміють статтю про біологічну зброю та сибірку, проте необов'язково зорієнтуються, коли подруга попросить купити тест-смужки для глюкометра. Вони зможуть розмовляти про захист навколишнього середовища, але їм складно буде пояснити, як користуватися посудомийною машиною тощо. Хороші студенти зможуть перекласти навіть складний текст, однак якщо їм доведеться розмовляти про фарбування стін чи паркування машини паралельно до бордюру, вони можуть мати проблеми. І така ситуація трапляється не тому, що програми навчання погані, просто система навчання створена так, що одночасно з розвитком мовних компетенцій, щоденне життя залиша- 
ється поза межами. Тут необхідно зауважити, що це стосується також інших мов - буває, що нам легше написати статтю іншою мовою, ніж пояснити, що барабан пральної машини не обертається.

Перша порада, яку можна почути від учителів і методистів у такій ситуації, - користуватися словниками та інтернетом. На жаль, поки що ці джерела допомагають далеко не завжди. У словниках відсутні нові лексеми, як напр. стайлер (вирівнювач), рідер тощо. А якщо йдеться про інтернет чи інші ЗМІ - у випадку української мови слід ставитися до них дуже обережно. Приклад: наведений стайлер в інтернеті також називають випрямлячем, вирівнювачем, щипцями, праскою, залежно від бренду та магазину. Згадані смужки для глюкометра в деяких магазинах з'являються у варіанті з російської (полоски). Це тільки два слова, які показують, що інтернет - не надто надійне джерело. Крім того, на багатьох веб-сторінках припускаються типових помилок або пишуть суржиком, отже краще, щоб ті, хто вивчає мову, оминали такі ресурси, щоб не запам'ятовувати неправильних варіантів. Середовище студентів складається не лише з іноземців, у групах є носії української як рідної, проте вони не завжди допомагають своїм колегам, адже зізнаються, що самі не все вміють назвати.

Тут виникає питання, чи справді ця проблема настільки серйозна, що варто присвятити їй час і задумуватися над нею? Сучасний світ дає можливість подорожувати і зустрічати людей з усього світу. Нікого не дивують «міжнародні» подружжя чи сусіди з інших країн. А саме в такому спілкуванні потрібна лексика повсякденного використання. I якщо погодитися, що навчання передусім має бути для життя, виявляється, що це справді проблема, про яку методистам слід пам’ятати.

3 досвіду роботи зауважимо, що варто присвятити час темі використання більш складної щоденної лексики і на вищих рівнях, щоб ті, кого навчаємо, зуміли порозумітися в будь-якій ситуації. Хоча, звичайно, це вимагає від викладача більше часу та зусиль. А з іншого боку, дуже важливим, зокрема 3 огляду на мовну ситуацію в Україні, $є$ те, щоб у побутовому мовленні використовували правильну, неспотворену українську мову. У цьому також можуть допомогти методисти, які рекомендаціями щодо введення і розміщення навчального матеріалу дозволять правильно побудувати весь процес викладання української мови як іноземної.

\section{Література:}

1. Антонів О., Паучок Л. Українська мова для іноземців: Модульний курс. К.: Фірма «ІНКОС», 2012. 268 с.

2. Антонів О., Романюк С., Синчак О. Україна-Польща : Dialog Kultur. Podręcznik do nauki jezyka Ukrainskiego. C1. Warszawa, 2014. $195 \mathrm{~s}$.

3. Буряк М. «Яблуко»: підручник з української мови як іноземної (базовий рівень). Львів: Видавництво УКУ, 2017. $268 \mathrm{c}$.

4. Мандрівка Україною : навчальний посібник з української мови як іноземної (рівень В2) / [Ірина Ключковська, Олеся Палінська, Ольга Пташник, Оксана Туркевич, Богдан Сиванич, Галина Шміло]. Львів: Дон Боско, 2012. $150 \mathrm{c}$.

5. Мій Львів : навчальний посібник з української мови як іноземної (В2) / [О. Антонів, О. Туркевич, П. Луньо та ін.]. Львів : Дон Боско. 80 с.

6. Палінська О. Крок-2 (рівень В 1). Українська мова як іноземна : книга для студента. Львів : Дон Боско, 2014. 160 с.

7. Палінська О. М., Туркевич О. Крок-1 (рівень А1-А2). Українська мова як іноземна : книга для студента. Львів : Артос, 2010. 100 с.

8. Синчак О. Яблуко: підручник з української мови як іноземної (вищий рівень). Львів 2015. - Львів: Видавництво УКУ, 2017

9. Delura S., Drobiszewska U., Kononenko I, Mytnik I., Romaniuk S., Saniewska M., Wasiak E., Zambrzycka M., Z ukraińskim na ty. Podręcznik do nauki języka ukraińskiego, cz.1, Warszawa: SOWA 2013

10. Delura S., Drobiszewska U., Kononenko I, Mytnik I., Romaniuk S., Saniewska M., Wasiak E., Zambrzycka M., Z ukraińskim na ty. Podręcznik do nauki języka ukraińskiego, cz.2, Warszawa : SOWA 2014

11. Jakubowska-Krawczyk K., Romaniuk S., Saniewska M., Украӥнською про культуру. Podręcznik do nauki języka ukraińskiego. Poziom zaawansowany wyższy, Warszawa 2018

12. Kosmeda T., Praktyczna nauka języka ukraińskiego (dla polskich studentów ukrainistyki A1-A1+), Poznań 2015

13. Kosmeda T., Praktyczna nauka języka ukraińskiego (dla polskich studentów ukrainistyki A2-B1), Poznań 2015

14. Romaniuk, S., Saniewska, M., Українською без табу. Podręcznik do nauki języka ukraińskiego, Warszawa, 2017

15. Zambrzycka M., Jakubowska-Krawczyk K., Romaniuk S., Культура і традииї Україниів: з минулого в сучасність. Підручник із завданнями, Warszawa 2018

16. Zinkiewicz-Tomanek B., Baraniwska O., Język ukraiński dla początkujących, Kraków 2012

17. Zinkiewicz-Tomanek B., Baraniwska O., Język ukraiński dla średniozaawansowanych, Kraków 2012 


\section{М. А. Матевощук,}

магістрантка Рівненського державного гуманітарного університету,

м. Рівне,

margomatewoschtschuk@gmail.com

\section{МЕТОДИЧНІ АСПЕКТИ ВИКОРИСТАННЯ ТЕХНОЛОГІЇ «ЩОДЕННІ 5» У ПРОЦЕСІ ФОРМУВАННЯ КОМУНІКАТИВНОЇ КОМПЕТЕНТНОСТІ УЧНІВ ПОЧАТКОВОї ШКОЛИ}

Актуальність проблеми зумовлена умовами реформування системи української початкової освіти, що вимагає формування учня, який може творчо самореалізовуватися, активно взаємодіяти з іншими людьми в суспільстві, вільно висловлюватися в усній і письмовій формі, брати активну участь у комунікативному процесі, створювати комунікативні ситуації і доречно вживати мовні засоби відповідно до завдань і мети спілкування.

Не так давно вчені стали виділяти компетентність як окремий підхід до навчання мови. Компетентісний підхід має на меті забезпечити формування сукупності компетенцій, якими має оволодіти мовець. Проаналізувавши Концепцію НУШ, Державний стандарт початкової загальної середньої освіти та навчальні програми чітко видно, що неабияка увага звернена на формування основних ключових компетентностей. Мовна компетентність $\epsilon$ пріоритетною, адже вона $€$ підгрунтям для розвитку всіх інших та займає чільне місце серед творчих проявів.

Психологічні фактори проблеми формування мовленнєвої компетенції викладені у працях М. Жинкіна, Л. Щерби, І. Синиці, Л. Виготського. Педагогічні та методичні питання іï формування розробляли сучасні вчені: В. Бадер, О. Біляєв, Т. Ладижинська, М. Пентилюк, Л. Мацько, Г. Шелехова, В. Мельничайко, Н. Голуб, О. Паршиков. Однак технологія Daily 5 (Щоденні 5) та іiі вплив на комунікативну компетентність не була на достатньому рівні досліджена, і саме цьому присвячена робота.

«Щоденні 5» (Daily 5) - це методична система, яку використовують у таких країнах світу, як Канада, Британія, Америка і Австралія.

Технологія навчання Daily 5 пройшла певний період розвитку, поки не стала важливою та актуальною в початковій школі Канади. Вперше вона була представлена Гейлом Буше і Джоан Мозер у книзі «The Daily 5: Незалежність грамотності в початкових класах» [5].

В Україні технологія «Щоденні 5» (Daily 5) була представлена як проект Міністерства освіти і науки України та платформи EdEra. Інструкції щодо роботи над цією технологією, впровадження кожного компоненту представила учитель початкових класів навчально-виховного комплексу «Новопечерська школа» м. Київ Марина Пристінська.

Аналізована технологія розвиває самостійність, креативність, уміння мислити нестандартно. Ця система складається 3 п’яти видів діяльності - «Письма для себе», «Читання для себе», «Читання для когось», «Роботи зі словами» $\mathrm{i}$ «Слухання», які діти виконують щодня під час уроків чи групи продовженого дня. Наприклад, щодня читають по 3-5-7 (а в четвертому класі і двадцять) хвилин, пишуть, слухають [3]. Тобто діти займаються усіма видами мовленнєвої діяльності, у процесі чого формують комунікативну компетентність.

Цікавою є думка М. Пристінської про те, що кожен вид діяльності сприяє відпрацьовуванню в дитини самостійності, витримки, зосередженості в процесі читання і письма протягом тривалого часу. Завдання, що виконують школярі під час Daily 5, можна обирати. [4]. На нашу думку, це підвищує мотивацію, оскільки дитина охочіше буде читати, слухати та писати про те, що їй подобається, творчість та інтелектуальний розвиток дітей.

Кожний вид діяльність триває певний час (до 20 хв). Після тривалого відпочинку учням важко зосередити увагу на тривалий час. Відпрацювання витримки під час впровадження Daily 5 відбувається 
від 8 до 12 тижнів. На початку цього процесу школярів об'єднують в одне велике коло, яке учитель розподіляє на групи для виконання навчальних завдань: одні пишуть, інші читають для когось, треті слухають. Через певний час знову сходяться в коло. Потім знову розходяться. І так триває до того часу, допоки кожен учень виконає всі п’ять видів діяльності.

Перший етап впровадження Daily 5 - це «Читання для себе». Його вчитель може застосовувати як під час уроку, так і впродовж дня. Він самостійно визначає час, коли йому краще проводити цю діяльність. Важливим моментом під час виконання цього виду роботи $є$ те, що учень самостійно обирає книгу чи текст для читання. Учитель не повинен нав'язувати свою літературу. Розпочинати цю діяльність потрібно із 5-10 хв. залежно від віку дітей і поступово збільшуючи час для читання. Коли учні звикнуть, проблем із читанням у школярів не виникатиме. У класі можна створити куточок «Читацьких досягнень», щоб учні могли спостерігати за своїми читацькими успіхами. Після опрацювання книги діти мають виконати завдання для перевірки розуміння твору, а також для усвідомлення прочитаного [1].

Другий етап Daily 5 - це «Читання для когось». Під час виконання цього виду роботи учитель може запропонувати учням текст для читання. А також учні за інтересами можуть самостійно обрати книгу для роботи. Під час виконання цієї діяльності учні об'єднуються в пари за інтересами. Такий вид діяльності спонукає дітей вчитися співпрацювати, а саме - слухати один одного, виконувати завдання в парі, ставити запитання за змістом прочитаного та аналізувати опрацьований твір. Учні мають виконувати «Читання для когось» впродовж 20 хвилин. Але не слід одразу їх примушувати працювати весь цей час [2].

Tретій етап Daily 5 - це «Слухання». В процесі виконання цього виду роботи учні самостійно обирають аудіозаписи, які наперед добирає вчитель, та слухають. Або ж у період гаджетилізації суспільства можна розглядати такий варіант, коли учень сам шукає аудіозапис на своєму гаджеті. Наприклад, cайт https://pustunchik.ua/ua, http://derevo-kazok.com.ua може стати в нагоді вчителя. Після завершення «Слухання» учні виконують завдання, які підготував учитель і які спрямовані на перевірку прослуханого. Під час «Слухання» учні вчаться тривалий час сприймати інформацію, не відволікаючись, відпрацьовувати витримку, обмінюватися думками щодо прослуханого твору, аналізувати почуте.

Четвертим етапом Daily $5 \epsilon$ «Робота зі словами». Його можна використовувати на уроках мови та читання. Під час цього виду діяльності вчитель добирає слова, які б він хотів опрацювати з учнями. Також використовує і ті слова, які передбачені навчальною програмою та запропоновані учнями незнайомі слова, які їм траплялися. У процесі «Роботи зі словами» учитель забезпечує школярів словниками, у яких учні можуть знайти визначення слів. Найкраще, щоб вони знаходилися в класі. Для пошуку тлумачення слів можна використовувати гаджети, якщо вони є в учнів. Учитель для цього виду діяльності готує учням різні завдання для роботи. Це сприяє кращому їх засвоєнню, а також дає змогу закріплювати вивчений матеріал на уроках української мови. Для цієї роботи використовують стіну слів. Це місце в класній кімнаті, куди вчитель розміщує всі слова, які учні вивчають впродовж місяця. Учні можуть у процесі навчання користуватися ними, звертати увагу на їх написання для кращого запам'ятовування. Стіна слів повинна перебуває в полі зору учнів [2].

П'ятий етап Daily 5 - це «Письмо для себе». Під час виконання цього виду роботи учитель може запропонувати учням будь-яку тему для письма. А також школярі за інтересами можуть самостійно обирати теми, наприклад, «Моя мрія», «Моя улюблена книга» та інші. Під час виконання цієї діяльності учні займають зручне для письма місце і впродовж відведеного часу працюють. «Письмо для себе» допомагає школярам вчитися висловлювати думки і записувати їх на папері, розвивати зв'язне мовлення. Як і в попередніх щоденних діяльностях, учитель разом із учнями складає правила, яких діти мають дотримуватися під час «Письма для себе». Так, під час «Письма для себе» учні мають змогу обрати таку тему для письма, яку б вони хотіли розкрити та, можливо, поділитися з іншими. Вони працюють як індивідуально, так і в малих групах, читають або пишуть в індивідуальній зоні. Відпрацьовування такої незалежності розвиває потребу в учнів краще писати та читати [1].

Отже, методична технологія «Щоденні 5» (Daily 5), що грунтується на діяльнісному підході, як цілеспрямований, планомірний та систематичний процес, у якому під керівництвом вчителя учні здобувають знання про навколишнє середовище, розвивають пізнавальні здібності, оволодівають певними мовленнєвими уміннями і навичками, навчаються взаємодіяти в соціумі, є засобом формування комунікативної компетентності учнів початкової школи. 


\section{Література:}

1. Відео-рекомендації Марини Пристінської - заступника директора НВК «Новопечерська школа». 2016. URL: https://www.ed-era.com/

2. Відео-рекомендації Оксані Хомич - вчителя початкових класів в НBК «Новопечерська школа». 2016. URL: https://www.youtube.com/channel/UCmj5jBaNuwTLQg9Y6vh4kQg/about

3. Пристінська М. Хочеш змін? Дій! 2017. URL: http://svitlanagalata.blogspot.com/2017/04/5.html

4. III серпневий інтернет-марафон «Сучасні методи розвитку мовлення і навчання читанню в початковій школі» Марина Пристінська - заступник директора НBК «Новопечерська школа». 2016. URL: http://www.edustartup. com.ua/.

5. The daily 5: fostering literacy independence in the elementary grades. Gail Boushey and Joan Moster, «the 2 Sisters». Second edition, 2014. 


\section{МОДЕЛІ ЛІТЕРАТУРНОЇ КОМУНІКАЦІЇ \\ В ХУДОЖНЬОМУ ТЕКСТІ}

УДК $82.02 \% .09$

O. A. Вісич,

доктор філологічних наук, дочент катедри украӥнської мови та літератури,

Національний університет «Острозька академія»

м. Рівне

oleksandra.visych@oa.edu.ua

\section{МЕТАДРАМАТИЧНІ СТУДІЇ У СВІТЛІ ШЕКСПІРОЗНАВСТА}

Методологічний арсенал сучасного літературознавства активно поповнюється новими підходами, серед яких все більшої актуальності набуває метадраматичний аналіз, в основі якого лежить осмислення драматичного тексту у світлі метадрами. Остання, своєю чергою, полягає у подвоєнні сценічного простору, специфічній диспозиції реальності та умовності, актуалізації ролі глядача тощо.

Перші метадраматичні студії, що почали з'являться від середини XX ст., переважно стосувалися реінтерпретації шекспірівської драми. Так, засновник концепції метадрами Л. Абель вважав, що Шекспір створив нову драматичну форму, яка не відповідала усталеним канонам трагедії, зруйнувавши кордони між п’єсою і самим життям [1].

У праці «Шекспірівська метадрама» (1971) Д. Л. Калдервуда однією з провідних тем дослідження є проблема самопрезентації та драматичної самосвідомості п’єс Шекспіра. Дослідник аналізує п'ять ранніх п’єс знаменитого драматурга, застосовуючи новітній підхід. Реалізація метадрами вбачається у взаємовпливі мови та дії в драмі. Калдервуд стверджує, що «власне театральне мистецтво - його предмет, його мова, його форми й закони, його співвідношення з правдою та соціальною ієрархією домінуюча тема Шекспіра, можливо, його найпостійніший сюжет» [2, с. 5].

Головним спадком поетики Шекспіра можна вважати прийом «театр у театрі» («Гамлет», «Сон літньої ночі», «Тік Андронік»), що якнайвиразніше оприявнює зникомість кордону між сценою і глядачем, реальністю та фантазією. Поширеним є використання прийомів ролі в ролі, рольової гри, маскування («Ромео і Джульєтта», «Сон літньої ночі», «Король Лір», «Венеційський купець»), що своєю появою активізують театральну саморефлексію. На думку Томаса Ф. Ван Лаана, одним із чинників самоферлексійності п’єс автора є так звані «внутрішні драматурги», персонажів із яскравою схильністю до маніпуляцій [5].

Адріан Мегарчанд у роботі «Метадраматичне прочитання трьох шекспірівських п’єс» [3] (1995) стверджує, що особливістю метадрами Шекспіра є зосередження на процесі творення, а не на результаті. Яцек Мидля в книзі «Драматичний потенціал часу в Шекспіра» [4] (2002), доводить, що метадраматичний потенціал п’єс Шекспіра полягає у подвоєнні часової структури п’єс Шекспіра.

Крім того в дослідженнях останніх років наголошується на таких метадраматичних прийомах, як: драма в драмі, внутрішня гра, як засіб верифікації опонента / злочинця, сон, фантасмагорія. Деформації сценічної умовності та метаізації п’єси сприяє також мотив безумства.

Загалом метадраматичний аналіз доробку Шекспіра не тільки дає змогу свіжого перепрочитання класика, але й виокремлення моделі шекспірівської метадрами, яка почне активно використовуватися у другій половині XX - на початку XXI ст. в абсурдистських, постмодерних, постдраматичних п'єсах. Розуміння суті шекспірівського коду, дозволяє виявити його ознаки, зокрема, і в українській літературі. Численні приклади переробок текстів англійського автора, алюзії на його персонажі та мотиви, цитування і рефлексії, а головне - відтворення метадраматичної структури фіксуємо у доробку М. Старицького, І. Карпенка-Карого, Я. Мамонтова, І. Костецького, Ю. Тарнавського та багатьох ін. Масштаби реалізації метадрами шекспірівського типу в український та світовій літературі, безперечно, зумовлюють перспективність досліджень в цьому напрямі. 


\section{Література:}

1. Abel L. Metatheatre: A new view of dramatic form. New York. 1963. 168 p.

2. Calderwood J. L. Shakespearean Metadrama: The Argument of the Play in Titus Andronicus, Love's Labour's Lost, Romeo and Juliet, A Midsummer Night's Dream, and Richard II. U of Minnesota Press. 1971. 202 p.

3. Meharchand A. A Metadramatic Reading of Three Shakespearean Plays: As You Like It, All's Well that Ends Well, Othello. Ottawa. 1995.

4. Mydlą J. Dramatyczny potencjał czasu u Szekspira. Katowice. 2002. $176 \mathrm{~s}$.

5. Van Laan T. F. Role-playing in Shakespeare. Toronto. 1978. P. 223-224. 
УДК 821. 161. 2-6

\section{C. О. Кочерга,}

доктор філологічних наук, професор кафедри

української мови і літератури Національного університету «Острозька академія»,

M. Oстрог,

svitlana.kocherha@oa.edu.ua

\section{ІМЕННИЙ КОД ПРОСТОРУ В ПОЕТИЧНОМУ ТЕКСТІ}

Традиційно певний простір (земля) вважається приналежністю автохтонного народу. Означниками просторового локусу можуть бути власники території, міфологеми про визначних людей, які залишили свій слід в історії краю, що, зокрема, репрезентують топоніми. Маркування тієї чи іншої локації нерідко пов'язане з його мешканцями (героями, страдниками, людьми непересічної долі), а також завойовниками. У тонкій матерії ноосфери, софіосфери кожне місце має віртуальне нарощення, що відбувається і завдяки його відображенню в художньому слові та асоціюється з конкретними авторами. Загальновідома фраза «Хочеш пізнати поета - треба поїхати в його край», яку приписують Й.-В. Гете, містить ідею, що ментальні особливості автора, його світоглядні пріоритети, своєрідність естетики закладаються у специфіці ландшафтів та її дифузії з товщами культурних пластів тієї чи іншої території. Водночас творчість регіональної знаменитості - це зазвичай і спроба осягнути genius loci. Талановитим письменникам притаманне глибоке проникнення в неповторну ауру тієї чи іншої землі, фіксування за допомогою метафоричного мислення особливостей, які опосередковано закріплюються на рівні читацької рецепції. Таким чином ім'я автора стає іманентною прикметою локації, а часом це стосується і його художніх узагальнень на кшталт розповсюджених найменувань об'єктів різного типу «Лісова пісня», «Мавка» на Волині. М. Лаюк образно фіксує таку закономірність: «Поет вписує себе (чи вписаний уже?) у певний пейзаж, пейзаж вписаний у певну географію, а географія в історію (історії)» [3, с. IX].

Варто наголосити, що не так важать біографічні факти художника слова, йдеться про мистецтво візуалізації локації, естетичну самобутність письма, що подекуди переростає в справжній культ простору. Такою, наприклад, є Кімерія М. Волошина, тобто частина узбережжя Криму, яку деякі вчені вважають зразком метагеографії, оскільки світ Кімерії - не лише витвір Бога, у спілці з ним працював різцем слова і пензля митець-деміург. Відтак природно, що турист, який опиняється в подібному просторі, сприймає його крізь призму літературних зразків, шукає слідів культового художника. Приміром, у вірші «Коктебель» П. Вольвача підкреслюється неповторність краю, який втілює прадавній міф: «За горами - жахи і катастрофи, А тут близьке вже золоте руно», яку вінчає «профіль поета над затокою» [2, с. 142].

Іменний код простору, осмислення якого є завданням нашої розвідки, стає містким і доволі промовистим у контексті художніх творів. На митців, які вже дали ірреальне життя конкретному місцю в художньому світі, свідомо або мимохіть орієнтуються й автори пізніших епох, письменники-мандрівники, спроби яких описати маршрут чи край приречені на вторинність, а їхня суб'єктивність повинна конкурувати з усталеними уявленнями, що з часом стають канонізованими відбитками простору в літературній творчості.

Уникаючи епігонства, поети охоче залучають код імені, завдяки чому їхня художня інформація стає місткішою, з ефектом стереофонічності, вона ніби піднімається на котурни. Таким чином літератори нових поколінь пропонують надбудову над шедеврами, що актуалізуються на рівні підсвідомості реципієнта. Прикладом ініціації простору іменем художника слова можна вважати рядки, в яких йдеться про землю, сходжену кимось з українських світочів(приміром, у творі М. Рильського «Слово про рідну матір»). Інколи біографічні відомості поступаються перед міфами, які знаходять продовження, наприклад, вірш «Львівська ніжність» І. Цілик - герметичний текст, побудований на фіміамі алюзій, протекст яких - творчість Б.-І. Антонича. Діалог з автором, що можливий тільки в певному місці, 
освяченому його присутністю тут в минулому, репрезентує поезія Мойсея Фішбейна «Крим. Осінь». Інколи йдеться про вкраплення в художню структуру поезії образів, що є прямою вказівкою чи алюзією на творчість іншого автора, наприклад, К. Москалець у своєму гуцульському шкіці «Мисливці на снігу» опосередковано апелює до В. Герасим'юка (шляхом вплітання образу «бездомних псів»), а О. Луцишина у збірці «Я слухаю пісню Америки» - до доробку Ф. С. Фіцджеральда. Популярна в спільноті вісімдесятників і постдесятників поезія Н. Білоцерківець «Ми помрем не в Парижі» втілює генетичну тугу ровесників за європейською культурою, що тривалий час була табуйована для «радянської» людини («Нам вони не дозволять померти в Парижі і воду / Під мостом Мірабо окільцюють конвоєм густим» $[1$, c. 8]). Однак інтертекстуальне декодування цього тексту неодмінно призводить до проекції на творчість Г. Аполлінера, автора вірша «Міст Мірабо», що для багатьох поціновувачів став символом проникнення в таїну стосунків чоловіка і жінки, філософію особистісного життя.

Загалом іменний код простору має доволі широкий спектр застосування в поезії. Окрім безпосереднього об'єднання імені митця (літератора) з певною територією, важливе місце у тексті належить інтертекстуальним проекціям, які дозволяють актуалізувати творчість конкретного автора. Вказаний прийом використовують як для рефлексій над простором вітчизняним, так і закордонним. Він дозволяє розширити інформаційний сегмент образності, додати елементи гри, інтелектуальної провокації, що особливо затребувано в сучасній постмодерній поезії.

\section{Література:}

1. Вісімдесятники. Антологія нової української поезії. Київ - Едмонтон, 1993. 206 с.

2. Вольвач П. Південний Схід. Поезії. Львів, Кальварія, 2002. 188 с.

3. Лаюк М. Вано Крюгер: парабіографія. Вано Крютер. Вертеп на Куренівиі. Київ, 2015. 80 с. С. IX-XVI. 


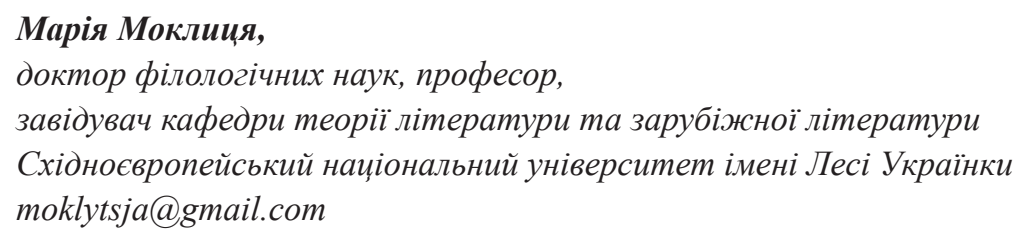

\section{СИМВОЛІЧНЕ МОВЛЕННЯ ТА ІНТЕРПРЕТАЦІЯ ТЕКСТУ (ДРАМАТУРГІЯ ЛЕСІ УКРАЇНКИ)}

Існує парадоксальна ситуація щодо вивчення трьох мовних образів - символу, алегорії, метафори. 3 одного боку, вони виділяються на будь-якому тлі потужністю створених дискурсів. Починаючи з часів Платона й Аристотеля, протягом тисячоліть ці мовні конструкти вивчаються науковцями практично всіх галузей гуманітаристики. Саме ці терміни часто трапляються у працях, досить віддалених від літературознавства. Але водночас професійні літературознавці, до того ж, першорядні, виявляють дивну непослідовність у використанні цих понять.

Символ, алегорія, метафора не просто мають найбільш потужні дискурси в історії європейської культури, а й очевидно протиставлені решті образних засобів широтою і складністю питань, які захоплюють. Головний біблійний постулат: Божественне слово, доповнене Словом / Богом у новозавітному християнстві. Але й у первісні часи, в політеїстичному світі, слово саме по собі має сакральний ореол, наділене магічною силою: створювати і руйнувати світ, визначати долю, знаходити місце під сонцем, творити інші основоположні діяння.

Дослідження твору - це пошук і фіксація доданих нових смислів. Художній текст багатошаровий i багатоплановий саме тому, що складається з образних слів, кожне $з$ яких нарощує смисли і утворює надтексти, підтексти і нову багатозначність, які дослідник повинен виявляти. Символічний, алегоричний і метафоричний способи інтерпретації тексту - це методи питомо філологічні, оскільки проросли 3 образного слова, вони не дозволяють літературознавцю втратити з поля зору специфіку свого об'єкта. І це вочевидь найбільш універсальні із відомих моделей аналізу й інтерпретації вербальної сфери культури, бо підтвердили свою дієздатність в процесі апробації протягом кількох тисячоліть.

Символічна інтерпретація тексту необхідна для виявлення смислів, доданих інтуїтивно-емоційним способом, алегорична потрібна, коли ми шукаємо додані раціональним способом смисли, метафорична інтерпретація неминуча при сприйнятті метафоричного твору і полягає у відновленні логіки ланцюга асоціацій, який призвів до виникнення парадоксальних уподібнень. Але починати завжди треба 3 етимологічного підходу, з виявлення тонких моментів актуалізації того чи іншого етимона, зафіксоване у морфології слова і його синтаксичних зв’ язках.

Інтуїтивне нарощення смислів виникає у творі внаслідок напруженого споглядання світу і себе в ньому. У такому разі твір зберігає природність, життєвість чи навіть певну реалістичність або й правдоподібність, але більш легку і прозору, ніж це властиво реалізму. Предмети, зберігаючи свою матеріальну природу і буквальне значення, натякають на існування чогось вищого і більш вагомого. Простежити, як конкретне значення розширюється і стає абстракцією, а згодом і філософським концептом - завдання реципієнта і дослідника інтуїтивно створеного тексту. Це сфера підтексту.

Символ «відповідальний» за божественний світ, за сакральне, за найбільш абстрактне й високоінтелектуальне із усіх здатностей людини. Символ вчить людину бачити за простими речами вічні форми (платонівські ідеї). Символ пов’ язаний з епіфанією (миттєвим осягненням божественності створеного, короткочасним явленням священного у профанному світі), а тому він миттєвий, позачасовий, невичерпний у відтінках значень (код священного у мирському).

Це серйозна гра/місія, періодична з'ява представників божественного світу поміж людей і стосунки 3 ними. Хоча знаковість предметного світу осягається переважно інтуїтивно-емоційним способом, 
символ вимагає усвідомлення позиції мовця щодо сакрального світу. Символ змушує людину розбудовувати світ абстрактних категорій. Тому символізм кінця XIX століття - найбільш філософський напрям.

Відчитування складних розгалужених значень, які утворюються в художньому тексті, - це насамперед розкодовування образної мови. При цьому важливо розмежовувати різновиди образів, але не тільки для класифікаційних потреб, як це роблять лінгвісти, а й для виявлення домінантного образу, який визначає парадигматику тексту. Талановитий автор прагне виробити індивідуальну мову, аби вона стала спроможною не тільки називати й описувати зовнішній світ, а й виражати найскладніші процеси внутрішнього життя. Вибір ключового образного слова відбувається інтуїтивно, але на якомусь етапі інтенсивно осмислюється і завдяки цьому набуває значно більшої ефективності.

Дослідники творчості Лесі Українки все ще сперечаються про ії стиль, ділячись на прихильників неоромантизму, більш традиційного підходу, легітимного у радянські часи і нібито базованого на поглядах авторки, і модернізму. Для діаспорного літературознавства (Ю. Бойко, В. Державин, І. Качуровський) характерне наполягання на неокласицизмі як домінантному стилі авторки. Праці, присвячені окремим творам, віднаходять у її творчості експресіонізм (дослідниці О. Головій, Г. Яструбецька про оповідання «Примара», драму «Одержима»), неореалізм (повість «Жаль»), імпресіонізм (у пізній поезії і прозі). Прихильників символізму можна знайти також серед діаспорних літературознавців (Ю. Бойко, М. Ласло-Куцюк), схилялась до цієї тези Н. Кузякіна, чимало студій символізму в драматургії Лесі Українки присвятила авторка цієї статті. 3 такою панорамою підходів можна було б погодитись, якби кожен фрагмент спостережень над стилем був чітко вписаний в загальну еволюцію творчості. На шляху пошуків авторського стилю можуть поєднуватись різні прийоми, засоби, відбувається стилізація чи пародіювання популярних форм. Але важливо збагнути, який саме із великих стилів епохи ліг в основу авторського стилю, саме того, який забезпечив вершинні здобутки митця.

Починаючи драмою «Блакитна троянда» (1897), Леся Українка створює новаторські символістські драми, твори, свідомо підпорядковані символістській меті: скеровувати погляд реципієнта від буденних тем до вічних, в кожній історії акцентувати проблеми сенсу життя і вищого призначення людини. Духовні цінності, занедбані в повсякденному житті, нагадують про себе вічними темами і образами. Про духовний вимір нагадують промовисті образи-символи, які природно виростають із сценічної предметної мови. Символи в драмах Лесі Українки настільки численні і природні, що часто не прочитуються на глибшому рівні, здаються простим антуражем. Але ії намагання кожну сцену промалювати в ремарках до найдрібніших деталей, вказати не тільки конкретні предмети, а й їх розмір, розміщення, колір свідчить про інше. Поступово предмети стають знаками, віщунами, застереженням, позначенням чогось глибшого і надто складного. Мова символів - тиха, ненастирлива, сповнена пауз і мовчання. Вона формує той тип драми, який від самого початку називали малодієвою і несценічною. Але важливо оформити сценічний простір так, щоб виникла атмосфера напруженого очікування, щоб глядач вслухався в тишу чи тихі звуки, звертав увагу на побутові предмети, які стають все більш важливими.

Якщо читач чи дослідник не акцентує уваги на символічній мові драматичних текстів Лесі Українки, він або прочитує їх поверхово, або, що частіше, нашаровує на текст свої упередження.

\section{Лiтература:}

1. Моклиця М. Алегоричний код літератури, або Реабілітація алегорії триває: монографія. К.: Кондор, 2017. $292 \mathrm{c}$. 


\author{
Д. Ю. Боклах, \\ здобувач кафедри украӥнської літератури, \\ Державний заклад «Луганський національний \\ університет імені Тараса Шевченка» \\ м. Старобільськ \\ dmytro.boklakh@gmail.com
}

\title{
ГОМОДІСГЕТИЧНИЙ НАРАТИВ У ТВОРЕННІ ТОПОСУ КИЕВА ПОВІСТІ «БЛИЗНЕЦЫ» Т. ШЕВЧЕНКА
}

Наративна поетика у творенні топосу Києва повісті «Близнецы» Т. Шевченка складає своєрідну художню площину урбаністичної атрибутики крізь рецепцію героя-оповідача як маркера дійсності міста.

Гомодієгетичний наратор - оповідач, який ретранслює історію, де сам виявляється бінарно: і як персонаж, і як викладова субстанція, що прагне до максимального відсторонення від безпосередньої подієвості [2, с. $253 ; 3$, с. 67].

Топос Києва - семіотичний конструкт цивілізаційно-природної дійсності міста, виявлений у локусах, що є місцями дії героїв у лінеарному просторі та складають психологеми сенсу їхнього буття.

Комунікативний дискурс організації поетикального наративу відтворення топосу міста у повісті «Близнецы» зосереджено навколо гомодієгетичного наратора в екстрадієгетичній ситуації, який веде оповідь від першої особи та проєктує предметний і духовний семіозис Києва.

Складність і заплутаність наративної композиції повісті дається взнаки при відтворенні урбаністичного простору Києва.

Наративну проєкцію Києва на початку твору змодельовано крізь оповідь про навчання Саватія Сокири у місті: «И отводил глаза на освещенную заходящим солнцем панораму старого Киева. Потом спускался вниз по террасе и выходил на Крещатик. Приходил домой, зажигал свечу и садился за какую-нибудь энциклопедию и окунал в чернила вместе с пером и светлый пламенник своей одинокой юности» [5, с. 74].

Наратор у повісті, на перший погляд, пасивний спостерігач, який ніби міметично відтворює географічну мапу Києва, апелюючи до власних ретроспективних спогадів. Однак бачимо, що за такою «маскою пасивності» сховано глибокі інтенції розуміння метафізики і сакрального ландшафту Києва, що свідчать про активізацію внутрішнього єства героя, яке співвідносне з Шевченковим alter ego. Присутня згадка про перебування Т. Шевченка в місті зазнає художньої модифікації у рецепції наратора: «я зашел к здесь же, на Московской улице, квартировавшему моему знакомому, художнику Ш[евченко], недавно приехавшему из Петербурга. Поговорил с ним об искусствах вообще, о живописи в особенности...» $[5$, с. 111$]$.

Гомодієгетична наративна матриця як образна комунікативна універсалія проєктує позачасове буття реалій предметного світу міста у ретроспекції, підкреслюючи винятковий естетизм архітектури, пройнятий одухотворенням: «Кто, посещая Киево-Печерскую лавру, не отдыхал на типографском крыльце, про того можно сказать, что был в Киеве и не видал киевской колокольни» [5, с. 110].

Оповідач твору вдало перемішує координати простору Києва й органічно створює ілюзію існування міста в різних часових площинах одночасно: «И после светлого, непорочного восторга... упадет на мое осиротевшее старое сердце тоска, и я переношуся в века давноминувшие и вижу его, седовласого, маститого, кроткого старца с писаною большою книгою в руках... Как ты прекрасен был в этой ризе кротости и любомудрия...» [5, с. 109]. Згадка про Андрія Первозванного, який освятив місцевість Києва, набуває особливої проникливості у тло минувшини завдяки імпліцитному читачеві, що самостійно має знайти змістову домінанту, яка дасть змогу пізнати сенс відображення Києва, його локальні психологеми та з огляду на хаотичність розповіді узгодити всі наявні у ньому архітектурні елементи. 
На думку О. Вещикової, потенціал імпліцитнго реципієнта є дуже потужним, оскільки читач отримує задоволення від виявлення інтертекстем [1, с.186], що стає одним з модусів проєктування візуальної матриці ландшафту міста.

Говорячи словами М. Ткачука, комунікативний зміст топосу Києва, тлумачення його референтного простору визначається адресатом - його статусом людини, позицією, світосприйманням, щохвлинним станом під час оповіді [4, с. 77]. Наратор весь час повертається у минуле (власне, історичне), яке стосується «теперішнього» моменту, тому завдяки цьому створюється гомодієгетичний аналепсис як своєрідний стрибок у часових площинах до послідовності творення світу топосу міста.

Отже, Т. Шевченко у повісті «Близнецы» реалізував прийом використання гомодієгетичного наратора у творенні топосу Києва. Наративний дискурс топосфери міста означений текстовими сигналами історії, ретроспекції, сучасного оповідачеві семіозису Києва, що вказує на об’єктивність цього наратора $з$ охопленням широкої панорами урбаністичної дійсності. Чітко простежується ірраціональний спосіб мислення наратора, що пов'язаний із синкретичним поєднанням різних оповідних конфігурацій та перипетій.

\section{Література:}

1. Вещикова О. С. Наративні стратегії мистичного у художньому творі (на матеріалі прози В. Шевчука, Г. Пагутяк, В. Даниленка) : дис ... канд. філол. наук: спец. 10.01.06 «Теорія літератури»; Чорноморський нац. унтет ім. Петра Могили. Миколаїв, 2017. 228 с.

2. Женетт Ж. Фигуры. Работы по поэтике. Москва: Изд-во им. Сабашниковых, 1998. Т. 2. 472 с.

3. Мацевко-Бекерська Л. Типологія наратора: комунікативні аспекти художнього дискурсу. Науковий вісник Миколаївського державного університету імені В.О. Сухомлинського. 2011. Т. 4. Вип. 8. С. 64-70.

4. Ткачук М. П. Наративні моделі українського письменства: монографія. Тернопіль: ТНПУ, Медобори, 2007. $464 \mathrm{c}$.

5. Шевченко Т. Г. Повне зібрання творів / редкол. : М. Г. Жулинський (голова) та ін. Київ : Наук. думка, 2001. T. $4.2003 .600 \mathrm{c}$. 


\section{О. А. Демчук,}

асистент підготовчого відділення для іноземних громадян

Центру міжнародного співробітництва та освіти,

Національний університет водного господарства та природокористування,

м. Рівне

olha.demchuk@oa.edu.ua.

\section{ІМАГОЛОГІЧНЕ ПРОТИСТАВЛЕННЯ ЕТНОТИПІВ У ПОЕЗІЯХ ВАСИЛЯ МАХНА}

Наукова думка все більше схиляється до сприйняття простору як впливового чинника самоідентифікації індивіда. На сучасному етапі досліджень почала формуватися сфера наукових студій феномену геопоетики, основною особливістю якої $є$ аналіз взаємодії особистості й довкілля. У контексті геопоетики вагоме місце належить імагології, що зосереджена на вивченні Свого й Іншого [2, с. 360]. Яскравим представником української літератури з вираженими імагологічними мотивами вважаємо Василя Махна - письменника часопростору, який мандрує світом у пошуках себе, як інтелектуальний кочівник [6, с. 10].

Джерельною базою нашого дослідження послугували праці Джоепа Лірсена, якого вважають одним із основоположників досліджень у руслі імагології, концепції філософа й культуролога Жана Бодріяра, котрий ініціював пріоритетність вивчення кодів, символів, справжності/штучності їхніх значень, наукові розвідки Богдана Рубчака та інших інтерпретаторів різноманітних аспектів творчості Василя Махна. Нині в науковому просторі відсутнє дослідження, сфокусоване на проблемі імагологічної опозиції Свого й Іншого в поезіях Василя Махна.

Мета роботи полягає в дослідженні імагологічного протиставлення етнотипів у поетичній творчості Василя Махна.

Доля митця-пілігрима під час мандрів світом - це зіштовхуватися з проблемами розмаїття аксіологічних, культурних, суспільних систем, що $є$ панівними в окремих країнах. Саме ці елементи утворяюють коди, що визначені часопростором і диференціюють різних індивідів [1, с. 81] Серед локусів, які формують у поезіях Василя Махна своєрідні надтексти, можна виокремити азійський (сакральний єрусалимьский, китайський), європейський, американський. Окремо слід виділити український, у якому його ліричний герой теж відчуває себе чужим. Це пов'язано зі стилем кочівного життя, що притаманний Василеві Махну, оскільки митець змінив місце свого проживання з України на Сполучені Штати Америки, що заважає йому почуватись вдома там і там. В описах екзотичних локацій поет наголошує на дискомфорті, базованому на відмінності інших. Його відштовхує мова, яка дуже подібна на гелготіння гусей, дратує запах риби, неохайність аборигенів, як-от: «рибу китайці купують щодень / продавиі у гумових чоботях / - наче сірі чаплі - / витирають в засмальцьовані білі фартухи / змамені риб'ячим жиром руки / телтотять і сміються» [5, с. 55].

Аналізуючи ізраїльські сакралізовані локуси, можна стверджувати, що по-справжньому Василь Махно пізнавав власний етнотип безпосередньо під час подорожі до Ізраїлю. Митець усвідомлює, що його творчість $є$ богоданною, позаяк письменник має талант бачити більше й відчувати світ сильніше, ніж інші. Автор натрапляє на простір абсолютного спокою: «співає з хасидами срібним горлом / $i$ дивиться мовчки як рояться гори /i будяки з травою / як діти біжать по камінному Цфату» [3, с. 53].

Коли в поезіях Василя Махна фігурує американський локус, у межах якого наразі він живе, реципієнт відчуває певну незатишність і своєрідний хаос, деструкцію в поведінці людей: «дорогою він заходить / до крамниці з алкоголем / $i$ купує / півторалітрову плящку Absolut'y» [5, с. 67]. Домінантною особливістю митця $\epsilon$ те, що він - типовий представник так званого безгрунтянства; позірно він став 
Іншим і для представників Свого етнотипу: «- кажуть у Штатах він пафос /- ну тачка бабло прибамбаси / - ість зелений фалафель /- по фіг йому і на фіг» [4, с. 30].

Отже, Василь Махно внаслідок майже перманентного стану мандрів втратив відчуття Свого, воно маргіналізоване в житті письменника, повністю підпорядковане пануванню Іншого. Трагедія мандрівника, загубленого в світі, полягає у відчутті вигнання, що сповна репрезентує напівприхована самоідентифікація ліричного героя Василя Махна. Проте такий спосіб життя для людини світу є водночас продуктивним способом пізнання багатоликості культури й утвердження загальнолюдських цінностей.

\section{Література:}

1. Бодріяр Ж. Символічний обмін і смерть. Львів : Кальварія, 2004. 376 с.

2. Лірсен Дж. Імагологія: історія і метод. Літературна компаративістика. Вип. IV. Ч. II. К. : Стилос, 2011. C. 362-376.

3. Махно В. Єрусалимські вірші/Jerusalem poems. К : Критика, 2016. 96 с.

4. Махно В. Паперовий міст. Львів : ВСЛ, 2017. 128 с.

5. Махно В. Ровер. Вибрані вірші та есеї 2011-2014. Тернопіль : Крок, 2015. 230 с.

6. Рубчак Б. Мандрівник, іноді риба. В. Махно. Cornelia Street Café: Нові та вибрані вірші. К. : Факт, 2007. С. 7-22. 


\section{С. М. Марчук,}

аспірантка кафедри української мови і літератури

Наиіонального університету «Острозька академія»,

м. Київ

svitlanamarchuk19@gmail.com

\section{ЕКЗОТИЧНІ МОТИВИ В СУЧАСНОМУ ПОЕТИЧНОМУ ТРАВЕЛОЗІ}

Сучасна українська мандрівна лірика суттєво збагатилась упродовж останніх десятиліть. Її «мапа» засвідчує істотну перевагу окциденталізму над орієнталізмом, оскільки нині автори насамперед відкривають для себе власний континент, зокрема міста, які слушно вважають центрами європейської культури. Окремі штрихи Орієнту репрезентують вірші, що віддзеркалюють Афганську війну, а також подорожі до Святих місць. У літературному надбанні кінця XX - поч.XXI ст. особливо заслуговують уваги цикл Ю. Андруховича «Індія» (1994) та книга Ганни Яновської «Золотий носоріг» (2019), які репрезентують далекі краї з самобутньою культурою, які досі в художньому світі української літератури залишаються «білою плямою». Варто наголосити, що засадниче ці два літературні проекти суттєво відрізняються: перший з них є відображенням ефемерної мандрівки, фантазії, а другий містить конкретний досвід. Водночас обидва ці тексти об'єднує екзотична палітра, химерність образотворення, що і є метою осмислення в нашій розвідці.

Автор поетичного циклу «Індія» Ю. Андрухович пояснював читачам, що в Індії він ніколи не був, а іiї образ створював як край світу відповідно до уявлень середньовічної людини. Н. Гаврилюк зазначає, що власне Індія постає у циклі як «конкретне місце на Землі й водночас фантастичний, екзотичний простір» [2, с. 43]. Побудова циклу поезії цілком відповідає композиції класичного травелога, заспівом до якого слугують рядки про спрагу подорожей. Далі подаються короткі відомості про Індію апріорі, що поєднують строгий науковий стиль і авторське фантазійне очікування. У другому вірші Андрухович «спростовує» відкриття відомого мандрівника XIII ст. Марка Поло, котрий першим залишив свідчення про землі та країни Азії, проголошує абсолютна довіру «приблуди» власній вірі та інтуїції. Досягнута мета перевершує сподівання, мандрівець підкорений ефектністю втілення мрійливих арабесок: «Увійшовши в хащі, де повно птиць, / уяви: природа - майстерня Бога, / по якій блукає твоя знемога. / Все, що можеш ти, - це упасти ниць [1]. Це місце населене дивовижним бестіарієм, його перетинає унікально прозора ріка, на узбережжі якої живе «люд», абсолютно не схожий на типове європейське населення, з незрозумілою мовою, незнайомим культом. Апогеєм принад інідійської землі стає віднайдений «вхід в Едем», який бінарно пов'язаний з «дірою», що веде в пекло. Фінал стає миттю вознесіння душі понад усіма тяготами життя. Цикл-травелог «Індія» можна вважати спробою міфотворчості, за допомогою якого автор передає свою тугу за незвичайним, втому від буденності, мрію вирватися з рутини повсякдення, що була близькою багатьом сучасникам поета. Один з найбільших поціновувачів циклу Ю. Іздрик зізнається: «”Індія" на довший час стала моїм приватним сакральним текстом» [3, с. 43].

Прикметно, що уявний травелог Ю. Андруховича спонукав до реальних подорожей прихильників його творчості, до яких, можна висловити припущення, належала і Ганна Яновська, поетична книжка котрої «Золотий носоріг» стала художнім відкриттям Африки. Як і в Ю. Андруховича, інший простір у Ганни Яновської теж певною мірою є явищем метагеографічним, оскільки багато в чому віддзеркалює авторську міфологію при зображенні реальної території, куди вона здійснила дві подорожі 2017 р. В основному її текст репрезентує міста Кейптаун, Дурбан, побережжя океанів, острів Роббенайланд, скелястий Мис Доброї Надії. Г. Яновська пропонує цілий спектр образів-«міражів» (Ж.-М. Карре), що містять прикмети африкофілії, яка почала формуватися до безпосередньої мандрівки - під час перекладів африканської поезії, а відтак у ній домінують не так замальовки на пленері, як «фікції, які колись в ході історичного розвитку виникли в певній країні чи спільнотах» [5]. Інколи авторка фіксує конкретні 
місця, де вона схоплює звичайні побутові африканські картини та огортає їх медитаціями над буттям різного масштабу. Екзотичні рослини Африки (бамбук, феніксове перо), каміння Понадбережжя, мушлі - всі ці екзотичні реалії лірична героїня приймає у жмуток споминів. У віршах Ганни Яновської помітні проникнення у часові нашарування, візуалізація африканських міфів, наповнення поетичною аурою мистецьких витворів, згадки про резонансні соціальні та національні події Африки. Окремої уваги заслуговує життя вулиці в очах туриста, що найбільш сконцентровано в поезії «Дурбан-блюз»: «Я пам'ятатиму всіх, я з пам'яті не зітру / Вулиці Дурбана - гомін, вікна пралень, крамниць...» [4, c. 58]. Кольори міста, його голоси, запахи, смаки (зокрема гострота спецій), окремі постаті, транспортні засоби - все це створює круговерть, що нагадує азартний танець, в епіцентрі якого лірична героїня почуває себе спокійно і комфортно.

Отже, образ екзотичної країни в поетичному травелозі - це практично завжди дискурсивний конструкт, художня модель геокультурного ландшафту, в якому важить і усталена традиція, і авторські світоглядна установка та ідіостиль. Уявне та реальне в химерному художньому світі зазнає дифузії. Однак у цілому цикл Ю. Андруховича насамперед засвідчує яскраве метафоричне мислення, образи, що потребують декодування, а книга Г. Яновської тяжіє до нон-фікшну в оболонці ліричних рефлексій.

\section{Література:}

1. Андрухович Ю. Індія. URL: www.ji.lviv.ua/ji,library/ukr,irr/ukr,irr,text.htm. (Дата звернення: 28.01.2020).

2. Гаврилюк Н. Поліметричний вірш періоду постмодерну («Індія» Юрія Андруховича). Слово і час. 2007. № 11. C. 42-48.

3. Іздрик Ю. Флешка-2GB. К.: Грані-Т, 2009. 248 с.

4. Яновська Г. Золотий носоріг. Львів, 2019. 96 с.

5. Dyserinck H. Imagology and the Problem of Ethnic Identity. Intercultural Studies: Scholarly Review of the IAIS. 2003. № 1. URL: http://www.interculturalstudies.org/ICS1/Dyserinck.shtml (Дата звернення: 30.01.2020). 


\section{О. А. Подвишенний,}

аспірант Наиіонального універстету «Острозька академія»

м. Рівне

gunsmoke1993@ukr.net

\section{ІМАГОЛОГІЧНЕ УЯВЛЕННЯ ПРО ЄВРОПУ НА ШПАЛЬТАХ ЧАСОПИСУ «ВОЛИНЬ» ПІД ПРОВОДОМ УЛАСА САМЧУКА}

У 1941 році Улас Самчук у складі однієї з похідних груп Організації Українських Націоналістів (мельниківців) покинув Прагу й повернувся до України. 20 серпня 1941 року Адольф Гітлер затвердив декрет про утворення Рейхскомісаріату «Україна» $з$ центром у Рівному. Поступово територія розширювалася, радянські війська відступали, і виникла гостра потреба створити органи місцевого самоврядування та культурно-просвітницькі центри з українців, які толерували б серед місцевого населення ідеї націонал-соціалізму та антибільшовизму. Таким чином, 1 вересня 1941 року побачив світ перший номер часопису «Волинь» під керівництвом Уласа Самчука.

Як зазначає Андрій Жив'юк, «публіцистику У. Самчука 1941-1943 рр. можна, з певною долею умовності, поділити на 3 частини: передовиці, репортажі, фейлетони. Так само варто виділити 3 групи серед передовиць: ситуативно-політичні, інструктивно-прикладні та самостійницькі» [3, с. 21]. Звернімо увагу саме на другу класифікацію публіцистичних текстів, що запропоновано нам паном Жив’юком. Якщо першій категорії - ситуативно-політичній - характерний реактивний характер, а третій самостійницькій - рефлексивно-змагальний, то саме твори, пов'язані з філософськими, світоглядними речами видаються найбільш актуальними під час дослідження окцидентального настрою письменника.

У період із 1941-1943 рр. на сторінках газети «Волинь» виявлено 129 дописів, що належать перу Уласа Самчука. Також він публікувався ще в кількох легальних під час німецької окупації друкованих органах, наприклад, «Голос Сарненщини», «Українка», «Орленя», «Школярик» і т.д. Письменник-публіцист формував цілий літературознавчий і громадсько-політичний дискурс краю в той період. Після відлиги від наївного захоплення й даремних надій щодо участі німців у становленні незалежної України, Улас Самчук разом з іншими членами редакції загострює акцент на потребах українського народу в осмисленні власної історії та участі в європейському житті континенту. Філософська концепція автора чітко декларована вже в передовиці «За мужню дійсність»: «Розбудова України і організація українського народу - ось основні гасла нашого часу (...) Ми переконані, що найліпшим свідченням політичної зрілості $є$ не кілька політичних груп, чи партій, а організовані і збудовані всі клітини національної спільноти народу» [3, с. 46]. Письменник закликає співвітчизників до єднання й національної солідарності, Друга світова війна для нього - це історичний шанс вийти 3-під влади імперської Москви, перехворіти постколоніальний синдром. На жаль, нацисти виявилися нічим не кращими, через що в 1942 році Уласа Самчука було тимчасово ув'язнено в Рівному за надто активну самостійницьку позицію.

У статті «Европа й ми» Улас Самчук рефлексує над тим, що таке Європа, іiі головні атрибути, хто ми, українці, на тлі тієї фантасмагоричної зміни світу, що відбувалася у воєнній дійсності. Автор влучно визначає дефініцію, яка, на його думку, відповідає духу доби: «Европейська духовність зо всіма іiї проявами культури, цивілізації та світоглядових рухів у певний період історії скупчується в одну активну, ударну воюючу силу, і та сила репрезентує основний зміст і сенс Европи» [3, с. 51]. Згідно 3 тезами німецького філософа Освальда Шпенглера, після Першої світової війни настав «захід Європи». Протягом усього міжвоєнного періоду цінності, уявлення про світ, розвій цивілізації у метафізичному сенсі скупчувалися, аж доки не настав big bang. Далі у статті Улас Самчук гостро критикує Московщину, яка завше була «пів-Европою, пів-Азією», гібридом, який ніяк не міг знайти в собі внутрішню рівновагу, через що постійно вів загарбницькі війни й нищив усе культурне, адже не міг того осягнути. Дослідниця Р. Радчик стверджує: «Самчук всією своєю творчістю обстоював українську націю як 
європейську, він різко виступав проти нав'язливої думки більшовицького «старшого брата» про те, що українці - не нація, а меншовартісна народність. Віковічне пригнічення української нації зовнішніми ворогами і віковічна боротьба українського народу за свої національні та людські права, на думку Самчука, повинні б мати логічне розв'язання цього складного питання саме в роки другої світової війни» [5]. Ці ідеї антикомунізму і психологічного образу українця-європейця є наскрізними фактично для всієї не лише публіцистики, а й белетристики письменника.

Він багато міркує над тим, що Україна, як складова Європи, покликана до творчості, патетичного лету. Нас, як в античному міфі, злі сили викрали з колиски цивілізації й хотіли знищити, але не можна знищити «надлюдей» (за Ф. Ніцше), тих, хто пройшов століття рабства і не скорився, хто дав світу таких титанів, як Шевченко і Франко, народ воїнів, поетів і господарів. Як зазначає Н. Кіор, «імагологію особливо цікавить Інше як інонаціональне й інокультурне, тому на перший план виходять у ній проблеми ідентифікації з етнокультурними спільнотами й образами цих спільнот. При цьому в імагологічних студіях ці образи розглядаються не тільки в їх відношенні до етнокультурних реальностей, а й у співвідношеннях з іншими образами ідентичностей, котрі розглядаються як рівноцінні» [4, с. 295]. У статті «Европа» Улас Самчук пише: «Гуманісти, а особливо соціалісти передреволюційного та революційного часу ані трошки не були гордими свого європейського походження. Було і $\epsilon$ ще безліч філософів, яким різниця між африканським мурином та європейським графом Цепеліном нічого не говорить» [3, с. 119]. Йому не зрозуміло, як людина може шукати щастя у вічному спокої, бовтанні в рутині життя, інтелектуальному пацифізмі. Європейці, зокрема українці, - це сильні нації, адже вони завше в пошуках, боротьбі з самими собою. Тут також ідеться про Донцовську формулу вольового націоналізму: «воля як закон життя; воля до влади», а інструментом отримання й утримання влади є боротьба. «І що ж лишається? Нічого іншого, як боротьба. Нічого іншого, як лишитися тим, чим створювала нас природа - європейцями... По натурі і упосібленню... По вдачі і світосприйняттю» [3, с. 120]. На думку автора, бути європейцем - це бути українцем, адже саме наша нація найбільше постраждала в горнилі війни за право називатися вільними людьми, за право творчості й свободи дії та вибору. Свобода, як зазначає Улас Самчук, - це думка, це хотіння, це амбіції кращого життя, незважаючи ні на що.

Проблематика газети «Волинь» розвивалася від українського екзистенційого питання - до європейського державницького контексту. Ідеї відродження Української Самостійної Соборної Держави брали витоки з історії національно-визвольного руху за незалежність України 1917-1921 рр.; концептуальні засади і принципи національно-державного відродження українського суспільства видавці «Волині» вбачали в консолідації національно свідомих сил. Свропа в уявленні Уласа Самчука - це метафізичний вибір між людиною і рабською твариною в обличчі тоталітарного комунізму. Українці a priori $\epsilon$ складовою європейського етнопсихологічного простору, а їх покликанням $є$ встановлення історичної справедливості і боротьба за свободу, вільну творчість, цивілізаційний напрямок розвитку народу на основі національної ідеї.

\section{Література:}

1. Буркалець Н. Мистецтво Уласа Самчука-публіциста (за матеріалами газети «Волинь»). Наукові записки тДПУ ім. В. Гнатюка. 2000. № 1(6). С. 21-27.

2. Гон М. Деперсоніфікація жертв: образ євреїв на шпальтах газети «Волинь» (1941-1943). Наукові записки [Інституту політичних і етнонаціональних досліджень ім. I. Ф. Кураса НАН Украӥни]. 2006. № 31. С. 113-121.

3. Жив'юк А. А. Документ доби. Публіцистика Уласа Самчука 1941-1943 років. Рівне : ВАТ «Рівненська друкарня», 2008. $454 \mathrm{c}$.

4. Кіор Н. Літературна імагологія: вивчення образів інших етнокультур у національній літературі. Питання літературознавства. 2010. № 79. С. 290-299.

5. Радчик Р. В. Газета «Волинь» та однойменне видавництво (1941-1944рр.) : Організаційний і проблемно-тематичний аспекти : автореф. дис. ... канд. філол. наук : 10.01.08. Київ, 2005.

6. Радчик Р. В. Публіцистика Уласа Самчука в контексті українського державотворення. URL : http://journlib. univ.kiev.ua/index.php?act=article\&article $=1333$.

7. Хороб С. С. Жанрові особливості журналістської публіцистики Уласа Самчука. Прикарпатський вісник НТШ. Слово. 2017-2018. № 4-3. С. 402-410.

8. Шаповал Ю. Г. Газета «Волинь» як український часопис (1941-1944рр.). Збірник праџь науково-дослідного центру періодики. 1994. № 1. С. 122-138. 


\section{I. Ю. Давидюк,}

магістрантка Національного університету «Острозька академія»

M. Острог

iryna.davydiuk@oa.edu.ua

\section{РОСЛИННІ ОБРАЗИ В ХУДОЖНЬОМУ СВІТІ ОКСАНИ ЛЯТУРИНСЬКОЇ-ПОЕТЕСИ: ЕСТЕТИКА І СЕМАНТИКА}

Рослинна поезія Оксани Лятуринської наразі недостатньо вивчена. Хоча ми знаємо поетесу як авторку своєрідного гербарію, «писанкарку в поезії» [1]. Витоки художньої системи Оксани Лятуринської вбачають у фольклорі. Однак у художньому мисленні поетеси флористичні образи-символи та архетипи набувають нового символічного звучання, смислових нашарувань, відповідних до тенденцій доби, особистого досвіду.

Серед дослідників творчого доробку поетеси важливими є роботи Ніни Анісімової, Оксани Сліпушко, Юрія Шевельова, Терези Левчук та інших. Проблему фольклоризму художнього мислення Оксани Лятуринської досліджувала Тереза Левчук. За іiі словами, фольклорний імпульс у мовно-поетичній творчості О. Лятуринської вмотивований поетичним, практичним та чуттєво-інтуїтивним осмисленням духовних надбань українського народу, що проявився на ідейно-тематичному, жанрово-стильовому, версифікаційному рівнях [2, с. 153].

Традиційно термін «фольклоризм» трактували як перелицювання усної народної творчості у творах мистців поетичного слова. Залежно від творчої манери письменника, його індивідуального стилю, способу перероблення фольклору як такого, розрізняли різні типи фольклоризму. Характерним для творчої манери Оксани Лятуринської є «внутрішній» або ж, за класифікацією Р. Марківа, - інтерпретаційний фольклоризм. Під яким розуміють рецепцію фольклорних мотивів, поетики, сюжетних ліній, «символічне переосмислення фольклорних й міфологічних першоелементів», усього того, що зберігає «дух» фольклору й глибокі емоційно-естетичні ціннісні орієнтири народної культури [4, с. 70].

Досліджуючи художню спадщину Оксани Лятуринської, Євген Маланюк звернув увагу на стислість іiї поетичного слова, його місткість та техніку мужньої недомовки, яку згодом назвав «суворою ощадністю слова». Найчастішим засобом фольклорного прояву у поетеси $є$ стилізація. Стилізуючи поезію під народну пісню, авторка вкладає в неї суто індивідуальний зміст, як-от у поезії «Жостір»: «Ой, копитом, ой, копитом / жито, жито збито! / Йшли з піснями, з прапорами, / маяли шличками» [3, с. 235]. Часті невмотивовані повтори, надмірна кількість вигуків, зокрема ритміка твору, вказують на зв'язок із народною піснею «Ой у полі жито». Щоб відтворити кореляцію людини з природою авторка застосовує засоби зображально-виражальної системи, зокрема персоніфікації, епітети, метафори, психологічний паралелізм. Як і в народних піснях, у поезії Оксана Лятуринська часто застосовує художній паралелізм: «Цвіт-калино, у садочку / пишно розвивайсь! / Мій, ти, любку-голубчику, / щасно повертайсь!» [3, с. 234]. Рідше вдається до історичних ремінісценцій: «Байді був я джура стало / $i$ до кроку, і до чвалу, чи Дін чи за Дністер, хоч не згадуй це тепер!» [3, с. 291].

Новою фольклорною хвилею 60-70-х років XX століття став літературний неофольклоризм. Перенасиченість творів фольклорним матеріалом підштовхувала до переосмислення народнопісенних знаків та атрибутів. Поети почали змінювати традиційне новими засобами художнього зображення дійсності, зокрема вдавалися до художньої трансформації фольклорних образів. Істотно новим елементом художньої творчості Оксани Лятуринської став саме неофольклоризм. Спадкоємиця давньої символіки зуміла оновити й збагатити іiі застосуванням засобів суміжних мистецтв [1]. Саме в таких поезіях найвиразніше проявилась індивідуальність поетеси. Схильність до витонченої споглядальної картини природи спричинила переосмислення традиційного образу-архетипу та творення власного поетичного міфу про осінь: «3 стежок почую сміх перлистий, / в корчах знайду разок намиста, / $і$ келихи джерел 
надпиті, / і дзеркало озер розбите» [3, с. 90]. На зміну безпосереднім фольклорним ремінісценціям прийшли опосередковані. Так, відлуння народної пісні у поезії «Впала нічка» набуває нетрадиційного сюжету. Замість дванадцяти традиційних трав для купальського вінка, Оксана Лятуринська насичує поезію «труйними стеблами»: «А на галявах, мова сміття / чарівного зілля, квіття. / А між квіттям уперекидь / в'юн, горчій, розхідник, блекіт» [3, с. 167]. Не відходить від бадьорої ритмомелодики авторка у поезії «Півники»: «Півники-косаточки / в жупаниях з блаваточки / ще досвіту гомонять: / Час косити починать» [3, с. 213]. Зберігши образність і поетичний синтаксис веснянки, спостерігаємо відлуння традиційної жниварської пісні, але мотиви важкої праці та недолі зажурених вдів у тексті поетеси маргіналізуються, традиційний сюжет зі скаргами презентовано оповитим меланхолійним настроєм.

Отже, поезія післявоєнного періоду Оксани Лятуринської просякнута мотивами народної творчости. Вона формує художнє мислення поетеси, увиразнює сутність ліричних персонажів. Однак авторка виходить за межі народних уявлень, пропонує їхню трансформацію, власне художнє вирішення, що дозволяє зафіксувати в художній палітрі Оксани Лятуринської дискурс неофольклоризму.

\section{Література:}

1. Кочерга С. О. Образ писанки в поетичному світі Оксани Лятуринської. Вісник Таврійської фундаиії (Осередку вивчення української діаспори) : Літературно-науковий збірник. Київ-Херсон : Просвіта, 2006. Вип. 2. C. 53-63. URL : https://prosvita-ks.co.ua/books/vtf/2vyp/vtf2-2.htm.

2. Левчук Т. П. Поетика Оксани Лятуринської : монографія. Луцьк : ПВД «Твердиня», 2012, 240 с.

3. Лятуринська О. Зібрані твори. Торонто : Вид-во Українок Канади, 1983. 813 с.

4. Янковська Ж. О. Фольклоризм української літературної прози доби романтизму : дис. ... д-ра філол. наук : 10.01.07, 10.01.01. / Львів. нац. ун-т ім. Івана Франка. Львів, 2017. 466 с. 


\section{T. В. Марценюк,}

магістрантка Національного університету «Острозька академія»

M. Ocmpoz

tetiana.martseniuk@oa.edu.ua

\section{ОБРАЗ ІНШОГО В ПОВІСТІ НАТАЛІ ЯСІНОВСЬКОЇ «УКРАЇНКА ПО-АМЕРИКАНСЫКИ»}

Вивчення образу Іншого набуває все більшої актуальності з огляду на інтенсифікацію міжкультурної комунікації в сучасному світі. Протягом XX ст. окреслився міждисциплінарний характер категорії «образ Іншого», адже вона фігурує у філософських, соціологічних, психологічних, лінгвістичних, культурологічних та ін. дослідженнях. Серед найбільш резонансних слід вказати праці М. Бубера «Я і Ти. Шлях людини за хасидським вченням», Ю. Крістевої «Самі собі чужі», П. Рікера «Сам як інший», Ч. Тейлора «Джерела себе», К. Юнга «Тінь» та ін. Аналізу репрезентації Іншого в художніх текстах присвячені імагологічні студії, що, зокрема, в українському літературознавстві представлені працями В. Будного, М. Варвадян, У. Гнідець, О. Колінько, Н. Моренець, Н. Шумейко та ін.

Літературознавча імагологія вивчає етнообрази, їх естетичну та змістовну специфіку, особливості авторського моделювання міжкультурної комунікації, проблеми національного самоусвідомлення та пошуку власного ідентифікаційного коду в багатокультурному світі.

Важливим матеріалом для дослідження художнього образу Іншого в українській літературі $є$ твори для дітей та юнацтва, у яких, зокрема на сучасному етапі, спостерігається активне звертання до імагологічної тематики. Вартими уваги вважаємо твори Л. Денисенко «Майя та їі мами», О. Лущевська «Скелет без шафи», Т. Стус «Різні люди» та ін. Саме через актуалізацію теми іншості в дитячій літературі виникає потреба іiі дослідження (який вплив комунікація з Іншим матиме на становлення особистості дитини, як це вплине на її буття у соціумі тощо).

Вважаємо доречним детальніше зупинитися на аналізі повісті Н. Ясіновської «Українка по-американськи» як твору, у якому вдало репрезентовано гетерообраз (образ Іншого). В основі сюжету лежить історія української дівчини, дванадцятирічної Марії, яка у шість років разом із сім'єю переїхала до Америки.

Формування уявлення про іншість в дитячий період стає критично важливим для подальшої картини світу людини. Саме в дитинстві з’являється страх перед чужим i, як стверджує В. Моренець, «ірраціональне, винесене поза рамки «свого» лише за браком ідентифікаційних ознак, стає «іншим», а тоді й поганим - просто за визначенням» [2, с. 13].

Натомість у творі Н. Ясіновської топос чужини стає тригером для національної самоідентифікації головної героїні, адже США зображені як полікультурне середовище, у якому мешкають представники різних національностей, котрі попри певну уніфікацію дотримуються власних культурних традицій. Марія змальована як типова сучасна американська школярка з відповідними смаками у музиці, одязі, спілкуванні з друзями. Водночас вона несподівано для рідних публічно демонструє національну приналежність: " - Думаю вдягнути вишиванку, - відповідає донька. // - Вишиванку? - мама здивовано піднімає брови...// - Так. Ми ж завжди вдягаємо вишиванки на Великдень і Різдво» [3, с. 179]. Зрештою культурна унікальність стає інструментом самореалізації та соціальної адаптації у світі Чужого. У повісті Н. Ясіновської іншість Марії сприймається не як чужість чи ворожість, а як передумова створення діалогу. Фактично, героїня переживає те, що в соціології детермінують як «ототожнення себе 3 образом Іншого», що «у процесі ідентифікації стає результатом набуття ідентичності - самовизначення соціального суб'єкта» [1, с. 222].

Отже, вивчення образу Іншого активно відбувається в гуманітарних науках протягом XX-XXI ст. Уважаємо, що дослідження з філософії, психології, соціології, літературознавства $є$ взамопов'язаними 
та взаємодоповнювальними і тільки в сукупності можуть дати цілісне уявлення про образ Іншого. Літературознавча імагологія здебільшого опирається на дослідження етнообразів у літературах, за яким можна ідентифікувати той чи той етнос. Сучасний світ розвивається в комунікації, тому відкидання чи ігнорування образу Іншого просто неможливе. Наразі українські письменники помітно актуалізували цю тему в літературі для дітей та юнацтва, що й викликає особливий інтерес та потребу у їх дослідженні. Повість Н. Ясіновської «Українка по-американськи» вдало репрезентує діалог культур, унаслідок якого образ Іншого сприймають не як чужість чи ворожість, а як цінність.

\section{Література:}

1. Гребенюк М. Самоідентифікація як механізм формування ідентичності особистості. Проблеми сучасної психологіï. 2010. С. 219-228.

2. Моренець Н. «Образ «Іншого» - від первинного нарцисизму до аргументу ідеологічної риторики». Наукові записки НаУКМА. 2002. С. 10-16.

3. Ясіновська Н. «Українка по-американськи». Харків : вид-во «Ранок», 2019. 208 с. 


\section{С. О. Омелянчук,}

магістрантка Національного університету «Острозька академія»

M. Ocmpoz

svitlana.omelianchuk@oa.edu.ua

\section{(НЕ)ВІЛЬНИЙ ШЛЮБ ТА ІНШІ ГЕНДЕРНІ ПРОБЛЕМИ ДРАМИ ВОЛОДИМИРА ВИННИЧЕНКА «ПРИГВОЖДЕНІ»}

Творчість Володимира Винниченка внесла чимало змін як у тогочасний літературний процес, так і в дискурс української літератури загалом. Новаторство письменника полягало, насамперед, у перепрочитанні стосунків між чоловіком і жінкою. Цьому сприяла Винниченкова філософія щастя - конкордизм. Письменник часто в своїх творах порушує такі незручні на той час теми, як вільне кохання, розкріпачення жінки, духовні і фізичні стосунки між чоловіком та жінкою, батьківство тощо. Це дає підстави аналізувати творчий спадок Винниченка у світлі гендеру.

Не позбавлена гендерних новітніх тенденцій драматургія Винниченка. Вона ставала об'єктом дослідження низки науковців (зокрема Лариса Мороз, Володимир Панченко, Віктор Гуменюк, Інна Кошова, Тетяна Свербілова, Наталя Малютіна, Світлана Уманець, Олександра Вісич, Людмила Тхорук та ін.). Однак у фокусі інтерпретативних студій досить рідко трапляється драма «Пригвождені», яка, на нашу думку, репрезентує дуже широкий спектр гендерних проблем. Лейтмотивом цієї драми є ідея «вільного шлюбу», що засвідчує й образна назва тексту. За переконанням головного героя Родіона Лобковича, «пригвождені» - люди, шлюб яких не приніс їм бажаного задоволення й перетворився на каторгу: «Тільки дві пари й знайшов щасливих, а сто двадиять три, що він знає, ті пригвождені» [1, с. 411]. Варто зазначити, що п’єса мала й іншу назву - «Розп'яті». Лариса Мороз трактує її як художню тезу: «...подружнє життя є хресною мукою, воно заперечує свободу особистості й заперечується цією свободою» [2, с. 150].

Ігнорування правил традиційного шлюбу Родіоном у творі Винниченка можна інтерпретувати як наслідок типового для свого часу (а по суті - травматичного) досвіду його батьків, які і $є$ одними 3 «пригвождених»: матір Родіона Устина Марківну без ії волі одружили з Тимофієм Лобковичем, оскільки він був багатим, що мало вагоме значення в тогочасному патріархальному суспільстві, яке толерувало «купівлю тіла» жінки. Однією з причин Родіона бути прихильником «вільного шлюбу» $є$ приклад його сестер, котрі, якщо не зраджують (Ольга), то мусять згоджуватися на співжиття зі своїм чоловіком через дитину (Настасія). Меншу сестру Ліму не приваблює приклад сестер: «...повіддавались через кохання, через справжне кохання. Одно одному в очі дивилось, зітхали, мліли, чого тільки не було. I Настя, і Ольга. А щзо тепер через сім-шість літ? Що? Пекло» [1, с. 416]. Проте вона все ж планує вийти заміж за нудного приват-доцента, бо зміни сімейного статусу від неї вимагає суспільство.

Натомість у Родіона переважає інший погляд на стосунки й одруження. Він - типовий Винниченковий герой-конкордист, що, як властиво поетиці письменника, закохується в різку, сміливу й чесну жінку. Його вибір - Калерія Прокопенкова - «з категорії фатальних жінок, в яких чоловіки легко закохуються і з якими важко поривають» [3]. Якщо в суспільстві існують абстрактні маркери абсолютного фемінного й маскулінного, то пара головних персонажів драми «Пригвождені» є художнім варіантом ідеалу Володимира Винниченка. Проте зазвичай такі стосунки письменник видозмінює на «любовний трикутник», що зумовлює гендерну дисгармонію. У нашому випадку «третім» є студент Гордий, слабкодухий і певною мірою токсичний, над яким Калерія помітно домінує, вдається до його «приниження» (останній комунікативний прийом «приниження» Володимир Винниченко використовує відносно часто). Яскравим прикладом цього є сцена, в якій Настасія змушує свого чоловіка Євгена цілувати їй чобіт - тоді вона, нібито згодиться віддати сина. 
Родіон Лобкович уособлює сильного «нового» чоловіка, який здатністю до спротиву та вільнодумством приваблює Прокопенкову, для якої мало бути вродливим і дужим фізично (Вукул) або ж бути закоханим і відданим (Гордий). Проте перипетії твору призводять Родіона до самогубства. На нашу думку, причиною фатального вчинку стала передусім усвідомлена неможливість досягти того, чого прагнув і сповідував Родіон - «вільного шлюбу», а ілюзія «здорової сім'ї» 3 часом неминуче перетворюється на комунікативні тортури. Самогубство Родіона не слід вважати виявом слабкодухості, це скоріше вчинок, який французький постструктураліст Мішель Фуко позиціонує як утвердження «влади над життям і тілом» [5].

У драмі «Пригвождені» також гостро висвітлено проблему батьківства, радше його визнання. Зокрема Тимофій Лобкович сумнівається в батьківстві деяких дітей, адже вони не мають ознак спадкової хвороби - божевілля. У праці «Від модерну до авангарду: жанрово-стильова парадигма української драматургії першої третини XX століття» влучно зауважено, що проблема сім’ї Лобковичів зовсім не в генетичній хворобі, позаяк стосунки в ній побудовані на взаємній ненависті, тиску й недовірі - проблема в тому, що ніякого зразка родини батьки своїм дітям не демонструють [4, с. 89].

Отже, ідея «вільного шлюбу» $є$ наскрізною в п’єсі «Пригвождені», іiї супроводжує ціла система взаємопов'язаної гендерної проблематики з характерним іiї постійним розгалуженням. Письменник зображує трагедію інституту сім'ї, розвінчує її необхідність, підкреслюючи деструктивні тенденції, руйнівні для особистості. У художній парадигмі моральні дилеми загострюють в таких сюжетних вузлах: нестерпність подружнього життя матері головного героя, яка свого часу стала заручницею патріархату; безглуздість шлюбу їі дітей, прагнення яких пристосуватися до законів суспільства виявилися марними; визнання батьківства як акцент на засадничому поколіннєвому відчуженні в сім’ї.

\section{Література:}

1. Винниченко В. Вибрані п’єси. Київ: Мистецтво, 1991. 605 с.

2. Мороз Л. «Сто рівноцінних правд» Парадокси драматургії В. Винниченка. Київ: Ін-т літ. НАН України; ВІ- ПОЛ, 1993. 208 c.

3. Панченко В. Творчість Володимира Винниченка 1902-1920 pp. у генетичних і типологічних зв'язках з європейськими літературами : дис. ... д-ра філол. наук: 10.01.01. URL: http://library.kr.ua/books/panchenko/index.shtml

4. Свербілова Т., Малютіна Н. Скорина Л. Від модерну до авангарду: жанрово-стильова парадигма української драматургії першої третини ХХ століття. Черкаси, 2009. 598 с.

5. Фуко М. Воля к истине - по ту сторону знания, власти и сексуальности. Работы разных лет. пер. с франц. М. Касталь, 1996. 448 с. 


\section{Н. В. Савчук,}

магістрантка Національного університету «Острозька академія»

M. Острог

nadiia.savchuk@oa.edu.ua

\section{«ПОЛЬОВІ ДОСЛІДЖЕННЯ 3 УКРАЇНСЬКОГО СЕКСУ» ОКСАНИ ЗАБУЖКО У ПОСТРАДЯНСЬКІЙ КУЛЬТУРНІЙ РЕЦЕПЦЇ̈}

Практично кожна національна література звертається до теми свого травматичного досвіду. Цей інтерес не випадковий, бо проговорення власної травми дає можливість позбутися іiї і зміцнити національну ідентичність. Подолання негативного досвіду - це заглиблення у ряд проблем, які аналізуючи можна вирішити.

У романі «Польові дослідження з українського сексу» особливим є те, що письменниця апелює до української ситуації, інтерпретуючи їі через життя головної героїні. Оксана Забужко - прозаїк динамічний, яка своїм художнім твором звертається до адресата і змушує його «прожити» текст, щоб віднайти ключі від вирішення проблем. У такий спосіб відбувається літературна комунікація між автором, нараторкою та реципієнтом. Пізнаючи художній світ письменника, твориться діалог із його ціннісними смислами, усвідомлення його світовідчуття. Те, як точно письменниця зображує травматичний досвід українців, ми можемо по пазлах скласти загальну картину пострадянської культурної рецепції. Авторка вдало використовує мову, як інструмент, оздоблюючи ії̈ багатою метафоричною фонікою.

Тексту притаманні філософічність, мислиннєві прориви та одкровення. Монолог нараторки іноді переривається звертаннями «Леді й джентельмени, пані й панове». Героїня Оксана ніби оголює перед читачем власне тіло, на якому залишилися травми минулого, що переслідують іï у житті. Як слушно зауважує Снс Герльт «Те, що починалося як опис нещасливого кохання та самотности, дуже швидко стає рефлексією з приводу визначального впливу українського минулого на вчинки та почуття двох людей. Тож цілу історію взаємного насильства, образ, поневолення і страждань можна розглядати як емблематичну ілюстрацію авторської візії української історії» [1]. Реципієнт сприймає розповідь героїні, як власну.

Апелюючи до тоталітарного дискурсу, письменниця виводить наскрізні роздуми роману - «Раби не повинні родити дітей...Бо це вспадковується» [2, с. 55]. Хоча Оксана мріє про сина від чоловіка-героя, який народиться без спадку страху. «Якого чорта було родитися на світ жінкою (та ще й в Україні!) - iз цією блядською залежністю, закладеною в тіло, як бомба сповільненої дії, з несамостійністю цією» [2, c. 12]. Це $є$ натяком на комплекс меншовартості, залежності та образу жертви. «Рабство $є$ інфікованість страхом. А страх убиває любов. А без любови - i діти, і вірші, й картини - все робиться вагітне смертю» [2, с. 111]. Це породжує трагічну любов та не дає спокійно жити. Себе ж героїня називає націонал-мазохісткою. Власна історія батьків Оксани стає відголоском радянської політики - мати, яка відчула на собі голод і батько якому довелося пережити арешт. Дівчині доводиться існувати під вічним контролем, навіть перше її захоплення - був насправді підісланий КГБ хлопець. Власний батько змушує доньку зняти сорочку, аби він міг бачити зміни тіла. Тут можна вбачати вплив його долі антирадянщика та колишнього в'язня ГУЛАГу. Власне минуле спонукає чоловіка до таких дій. «Од відкритости своєї тайни - ну але які ж тайни можуть бути од татка?» [2, с. 104]. Життя у вічному страху, який передається у спадок.

«Роман «Польові дослідження з українського сексу» Оксани Забужко став першим у 1990-х, який безпосередньо апелює до травматичного досвіду українців (голоду, репресій, ув'язнень і розстрілів інтелігенції), що позначився на світогляді і, зрештою, визначив долю багатьох представників покоління головної героїні Оксани»[4, с. 192]. Все своє дитинство та молодість нараторка зазнає приниження та перетворюється на жертву - це все є наслідком упосліджености ії нації. Історична пам'ять впливає на 
інтимні стосунки героїв. Побитий слабкий чоловік не може жити з сильною жінкою. Оксана Забужко вдало прописує образ держави «А в Україні що, Україна - це Хронос, який хрумає своїх діток з ручками й ніжками» [2, с. 17]. Система нещадно б’є власний народ, який ще не вмер. На сторінках роману героїня Оксана стає дзеркалом, що відображає загрози та конфлікти.

Отже, у романі «Польові дослідження з українського сексу» Оксана Забужко звертається до травматичного досвіду реципієнта. У такий спосіб апелюючи до широкого читацького кола наголошує на зовнішніх загрозах для існування нації. Нам не потрібно бути спостерігачами, не задовольнятись простим існуванням, не боятись говорити та ламати застарілу систему.

\section{Література:}

1. Герльт Є. Польові дослідження націоналістичного дискурсу : випадок Оксани Забужко «Україна модерна». 2009. №14 (3). URL : http://uamoderna.com/images/archiv/14/17_UM_14_Dyskusii_Gerlt.pdf

2. Забужко О. Польові дослідження з українського сексу. Видання тринадцяте. Київ : КОМОРА, 2019.120 с.

3. Зборовська Н., Ільницька М. Феміністичні роздуми. На карнавалі мертвих поцілунків. Львів : Літопис, 1999. $336 \mathrm{c}$.

4. Пухонська О. Травматична пам'ять культури та ії літературна репрезентація. Наукові записки Наиіонального університету «Острозька академія». Серія «Філологічна» : збірник наукових праць. Острог, 2016. Вип. 62. C. $289-292$. 
Наукове видання

\title{
ЛЕКСИКО-ГРАМАТИЧНА СИСТЕМА УКРАЇНСЬКОЇ МОВИ В КОМУНІКАТИВНОМУ ВИМІРІ
}

\author{
Збірник матеріалів Міжнародної наукової інтернет-конференції \\ 12-13 березня 2020 року
}

Відповідальна за випуск Зоя Столяр

Комп'ютерна верстка Наталії Крушинської

\begin{abstract}
За достовірність наведених фактичних даних, иитат, власних імен, географічних назв та інших відомостей відповідають автори.
\end{abstract}

Формат 60х84/8. Ум. друк. арк. 8,83. Електронне видання. Зам. № 28-20.

Папір офсетний. Друк цифровий. Гарнітура «Times New Roman».

Оригінал-макет виготовлено у видавництві

Національного університету «Острозька академія»,

Україна, 35800, Рівненська обл., м. Острог, вул. Семінарська, 2.

Свідоцтво суб' єкта видавничої справи РВ № 1 від 8 серпня 2000 року. 